IZA DP No. 6057

The Global Economic Crisis:

Long-Term Unemployment in the OECD

P.N. (Raja) Junankar

October 2011 


\title{
The Global Economic Crisis: Long-Term Unemployment in the OECD
}

\author{
P.N. (Raja) Junankar \\ University of New South Wales, \\ University of Western Sydney and IZA
}

Discussion Paper No. 6057

October 2011

\author{
IZA \\ P.O. Box 7240 \\ 53072 Bonn \\ Germany \\ Phone: +49-228-3894-0 \\ Fax: +49-228-3894-180 \\ E-mail: iza@iza.org
}

Any opinions expressed here are those of the author(s) and not those of IZA. Research published in this series may include views on policy, but the institute itself takes no institutional policy positions.

The Institute for the Study of Labor (IZA) in Bonn is a local and virtual international research center and a place of communication between science, politics and business. IZA is an independent nonprofit organization supported by Deutsche Post Foundation. The center is associated with the University of Bonn and offers a stimulating research environment through its international network, workshops and conferences, data service, project support, research visits and doctoral program. IZA engages in (i) original and internationally competitive research in all fields of labor economics, (ii) development of policy concepts, and (iii) dissemination of research results and concepts to the interested public.

IZA Discussion Papers often represent preliminary work and are circulated to encourage discussion. Citation of such a paper should account for its provisional character. A revised version may be available directly from the author. 


\section{ABSTRACT \\ The Global Economic Crisis: Long-Term Unemployment in the OECD*}

This paper analyses the impact of the global economic crisis on unemployment and long term unemployment in the OECD. It uses simple econometric models using panel data (quarterly) and time series data. In general, we find that long term unemployment increases with the unemployment rate, there is persistence in long term unemployment, and that the employment protection variable and the replacement rate are statistically insignificant. Overall, the findings of our research are that there are many differences between the impact of the Great Recession on different countries. Countries that faced a significant financial crisis and a collapse of the housing market bubble have had large increases in unemployment and long term unemployment. There was a big fall in employment in the (especially) construction and manufacturing industries. The financial collapse led to an increase in unemployment in the financial and business sector. As a result of these twin shocks labour mobility of the unemployed is likely to be affected: with negative equity in housing, unemployed workers are unlikely to move regionally. With a loss of wealth (in housing and financial assets, including superannuation) there will be a fall in consumer spending which will slow down the recovery of economies. This means that, especially for some countries, there will be a long period of high unemployment and long term unemployment.

JEL Classification: $\quad$ E24, J60, J68, J69

Keywords: long-term unemployment, global crisis, labour market policies, OECD

Corresponding author:

P.N. (Raja) Junankar

School of Economics and Finance

College of Law and Business

Campbelltown Campus

University of Western Sydney

Locked Bag 1797

Penrith South DC, NSW 1797

Australia

E-mail: raja.junankar@uws.edu.au

\footnotetext{
* The author acknowledges the financial support of the OECD for this research. The views expressed are those of the author and do not necessarily represent those of the OECD or its member governments.
} 


\section{The Global Economic Crisis: Long Term Unemployment in the OECD ${ }^{1}$ P.N. (Raja) Junankar}

\section{Introduction}

A prolonged period of unprecedented growth in most OECD economies since the middle of the 1990s (except for a temporary crisis in 2001), was ended suddenly by the Global Financial Crisis (GFC) and its aftermath. The "Great Recession" that followed has been the most severe recession in recent years. In some countries, especially the USA, the UK, Ireland, and Spain, the combination of a financial crisis with the bursting of the housing bubble dealt a severe blow to their economies. Even though many countries are now slowly coming out of the recession with modest growth in GDP, it will be some time before unemployment rates will fall substantially. Although many countries have survived the Global Financial Crisis (GFC), some countries in the Eurozone are apparently teetering on the brink of financial breakdown as a result of the debt crisis: after the Greek crisis and the Irish bailout, there have been rumours of the imminent collapse of Portugal, Spain, and perhaps Italy. At present, even Italy and France have had their ratings downgraded by Moodies. All this uncertainty leads to a cautious response by firms about investment in new capital goods: investment in real capital remains stagnant. In addition, the sudden fall in wealth of many consumers due to a fall in house prices and in equity prices has slowed the growth in consumer expenditure. Further, the financial crisis has led to a tightening of credit by financial institutions to firms. These factors are likely to slow down the recovery from the Great Recession. The impact of the recession has been unevenly distributed across the OECD: some countries like Australia officially did not have a recession (GDP growth was negative for only one quarter), while other countries like Germany bounced back very quickly.

In the wake of the Great Recession we have seen a crisis in the labour markets of many countries, with escalating unemployment rates and consequently a growth in long term unemployment. The number of unemployed persons in the OECD went up from 30.6 million in 2007 (Q4) to 47 million in 2010 (Q2), while the long term unemployed went up from 8.5

\footnotetext{
${ }^{1}$ I am grateful to Robert Wells and Jenny Wong for excellent research assistance with the econometric analyses. Extensive comments by Paul Swaim, OECD, on an earlier draft have made a significant improvement and I thank him for his help. Comments by Cezary Kapuscinski, Department of Education, Employment and Workplace Relations, Commonwealth of Australia, and by Professor Geoff Harcourt, University of New South Wales are gratefully acknowledged. I am, of course, responsible for remaining errors and for views expressed.
} 
million to 14.9 million. The growth of unemployment and long term unemployment has serious economic, social, and human costs. Past history suggests that once the unemployment rate increases it takes a very long time for it to return to the pre-recession levels: often times economies are hit by another recession before that happens. Long term unemployment increases, after a lag, with the increases in unemployment, and also takes a very long time before it comes down to previous levels.

Many OECD countries had introduced labour market reforms that increased the use of casual/temporary workers and decreased the strictness of employment protection legislation. As such in the Great Recession, many more workers faced unemployment as temporary workers contracts were not renewed or they were laid off.

The Great Recession had led most countries to introduce crisis measures to tackle unemployment: monetary policy was suddenly relaxed with central banks lowering interest rates to almost zero, increasing money supply (quantitative easing); and expansionary fiscal policies were introduced. It is generally accepted by many economists, and leading international organisations (e.g. the OECD and the IMF), that the crisis measures introduced (both monetary and fiscal) helped to attenuate the fall in GDP and rise in unemployment. However, after a short period many Governments were no longer willing to continue the crisis measures of expansionary fiscal policies, and began to cut back on government expenditures and began to worry more about government budget deficits rather than the state of the labour market.

This paper provides an analysis of long term unemployment in the OECD during the Great Recession and in the early recovery period. The paper argues that the growth of long term unemployment is a necessary consequence of the growth of unemployment rate. Although most OECD countries had an increase in unemployment rates, a few managed to turn around the economies and to lower unemployment rates. These economies, Australia and Germany being good examples, had a relatively small increase in long term unemployment which began to come down relatively quickly. Other economies, in particular the USA, Spain, and Ireland, had a massive increase in unemployment rates and consequently in long term unemployment. Even though the unemployment rates are now beginning to come down, the long term unemployment rates are still rising. A comparison of the growth of long term unemployment during this so-called Great Recession with previous recessions shows that 
some countries performed worse in this recession: the USA has had a historic rise in unemployment (in about thirty years) and a massive increase in long term unemployment.

Unemployment is a very unjust and undemocratic punishment. It hits disadvantaged groups in society: the young, the unskilled, ethnic minorities (the blacks in USA, indigenous Australians, etc.) and migrants. The long term unemployed are not only a wasted resource, they are also a wasting resource. The long term unemployed not only lose their skills, they lose motivation, they fall ill: in crude economic terms human capital is being depreciated. In human terms there is a mass of misery and suffering: often they live in poverty, they have lost their self respect and dignity and they accept the verdict of the labour market with a mixture of resentment and resignation. The social implications of this are very serious: some people argue it leads to increased social strife, growth of right wing extremist parties, antiimmigration campaigns, riots, divorce and family breakdowns, illness, and death, see Aaronson et al. (2010), Dao and Loungani (2010), Junankar (1986, 1987), Junankar and Kapuscinski (1991), Saunders and Taylor (2002). In this context it is important that OECD countries engage in a "war” on long term unemployment!

\section{Unemployment and Long Term Unemployment: An Analytical Framework Some Conceptual Issues}

There are often two data series for unemployment available: Labour Force Sample Surveys (based on the International Labour Organisation, ILO, conventions) and the administrative data on Unemployment Benefit Recipients. According to ILO conventions, to be unemployed a person must not have been working for pay or profit for one hour or more in the last week, must be looking for work in the past four weeks, and must be available to start work in the following week. From an economist's perspective, it is important to note that the survey does not mention at what wage they wish to find work. The ILO series are based on sample surveys and are subject to sampling variability. In addition the data are subject to recall errors and to respondent error. The administrative data are based on a complete count of the unemployment benefit recipients and hence are not subject to sampling error. However, if a person moves from unemployment benefits to sickness benefits and then returns to unemployment the person is counted as having a "zero" duration, while s/he may think of it is as a continuous spell of unemployment. Another problem with using this administrative data to compare changes in unemployment over time is that conditions for accessing unemployment benefits change and hence there is no consistency in the time series data. 
Following a common convention, a person is deemed to be in long term unemployment in this paper if s/he has been unemployed continuously for 12 months or longer. However, the strict definitions of unemployment and long term unemployment generally provide a lower bound estimates of the true extent of involuntary joblessness and underemployment: some of the unemployed workers give up searching for work (discouraged workers), others (especially the young) may decide to move into educational institutions ("encouraged students”), and some who work part time would prefer to work longer hours but are unable to obtain work.

Similarly, the long term unemployed numbers are likely to be underestimates because if a person who was unemployed finds temporary (casual) work for a week or so, s/he typically would be reported as beginning a new spell of unemployment and hence be removed from the list of long term unemployed. If a person enters a brief labour market program (say a training program) s/he is also likely to be removed from the list of the unemployed and would begin a new spell of unemployment. If an unemployed person falls ill for a short period, s/he also tends to return to the unemployed stock with a new spell (in effect is "re-born" with a zero duration). The long term unemployed are also more likely to fall ill, and hence have their unemployment spell broken. Some workers have many recurrent spells of unemployment that if added up over a few years would in fact constitute long term unemployment (interrupted by short spells of work or inactivity), see OECD (2002).

Measures of long term unemployed are measures of so-called "interrupted spells": a person may be unemployed for only 11 months at present, but will remain unemployed for another 2 months but is at present not a long term unemployed person. During the early stages of a recession there may be many unemployed persons who, although unemployed for less than 12 months, would eventually remain unemployed for 12 months or more (this leads to “interruption bias”). A counter-weight to this is that due to the sampling procedures there is a greater probability that a long term unemployed person would be in the sample ("length bias”).

We define the numbers in long term unemployment (the unemployed with durations of twelve months or longer) as NLTU.

A measure of long term unemployment that is commonly used is the incidence of long-term unemployment. This is the proportion of unemployed persons who are long-term 
unemployed. In this paper we use the term Proportion of Long Term Unemployment (PLTU) for this concept.

Sometimes an alternative measure is used called the long-term unemployment rate or the rate of long term unemployment (RLTU) which is defined as the number of long-term unemployed in any group expressed as a percentage of the labour force in that same group. In a recession, the numbers in long term unemployment (NLTU) increase, but initially the proportion of long term unemployment (PLTU) falls. After the recession continues for some time, PLTU increases. In general, the proportion of long term unemployment (PLTU) and the rate of long term unemployment (RLTU) move in a similar fashion, except when the labour force changes substantially. A comparison was made for a few countries, and there was a very high correlation between the PLTU and RLTU measures.

There is no obvious way of showing that any one of these metrics, NLTU, PLTU, or RLTU is a superior measure of long term unemployment. Which method is used depends on the question at hand. If we are interested in the increase in human suffering (misery) of the unemployed, we could use an increase in NLTU as reflecting how many more people are suffering from long term unemployment. However, the larger the population, the larger the numbers of unemployed for any given unemployment rate and hence the larger the number of long term unemployed, ceteris paribus. In population theory, we often use the concept of the dependency ratio (the percentage of people over retiring age plus the school aged children as a proportion of the total population). This normalisation is very common in population studies. Similarly, in studies of long term unemployment it is common to normalise the numbers of long term unemployed by the total numbers of unemployed people (measured as a percentage (PLTU). An alternative normalisation is to take the numbers of long term unemployed as a proportion of the labour force (RLTU). Given that the labour force is much larger than the total numbers unemployed RLTU is much smaller that PLTU and we would have to calculate RLTU to many more decimal places to be able to notice any change. In general, the labour force does not change very much in the short run, so that it is almost a constant, see Figure 5. Hence changes in NLTU would be reflected in changes in RLTU.

If we are comparing changes over time of these measures of long term unemployment, we could use the percentage increase over a period of time of NLTU, PLTU, or RLTU. Alternatively, we could use the percentage point increase in PLTU or RLTU. If we are 
concerned about the long term unemployed then a five percentage point increase when PLTU is five percent is not as serious as a five percentage point increase when PLTU is fifty percent. In the subsequent discussion we will provide some alternative metrics for long term unemployment.

Figure 1: Unemployment: Stock and Flows

Unemployment: Stocks and Flows

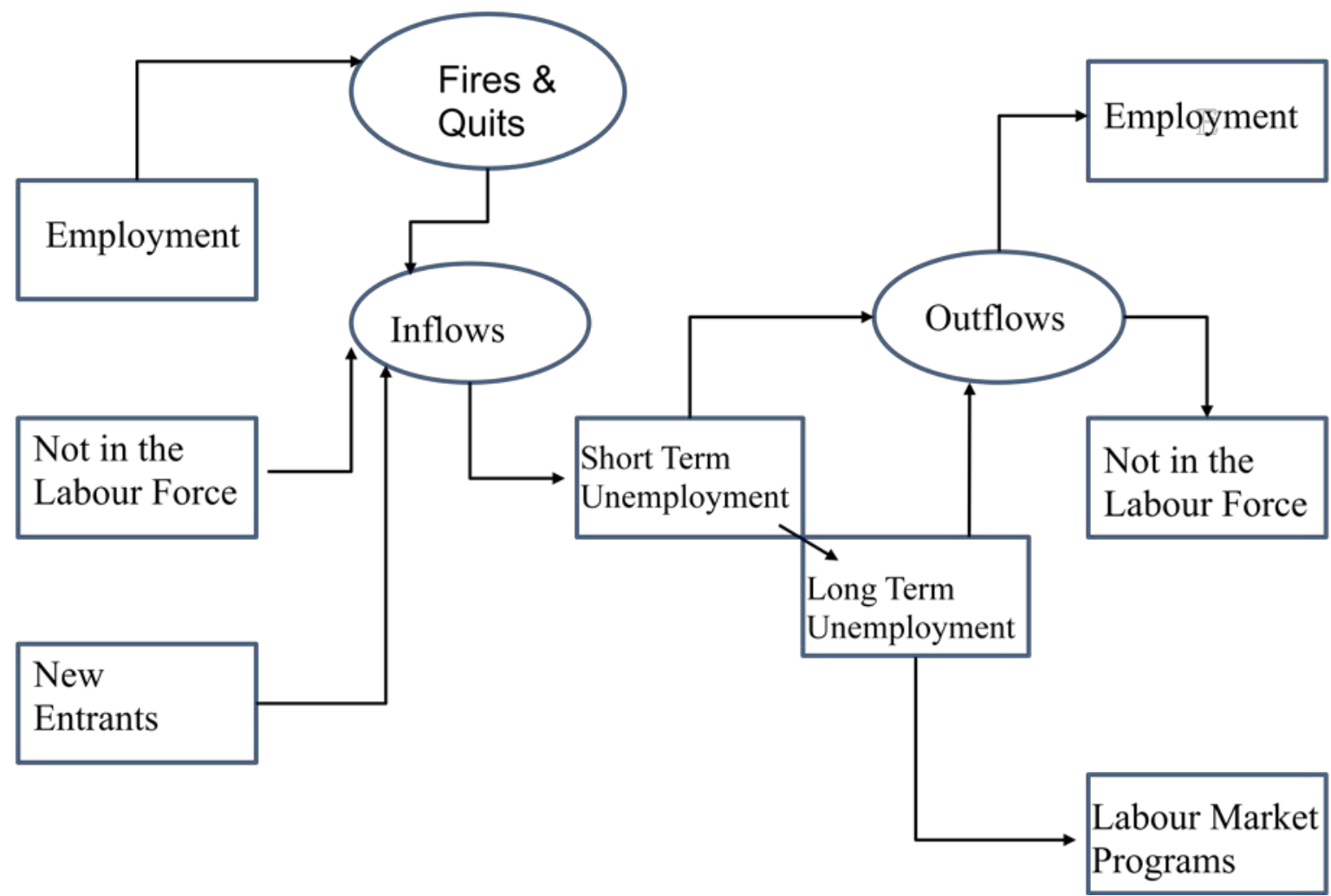

Usual measures of unemployment are measures of the stock of unemployment at a point in time. The labour market is in a continual state of flux with large movements between different labour market states. Changes in this stock of unemployment come about by inflows into the stock and outflows from the stock. The inflows (those joining the unemployment stock) may have come from employment, not-in-the-labour force (NILF), or new entrants (some from educational establishments). The outflows from unemployment may find work, leave the labour force (retire early fall, sick, or give up hope, i.e. join the NILF), or go into labour market programs, e.g. training schemes, see Figure 1. In simple form: 


$$
\mathrm{U}_{\mathrm{t}}=\mathrm{U}_{\mathrm{t}-1}+\mathrm{I}_{\mathrm{t}}-\mathrm{X}_{\mathrm{t}}
$$

where the U's are unemployment stocks at the end of periods, and I denotes inflows into the unemployment stock and $\mathrm{X}$ denotes outflows ( $\mathrm{X}$ for exits) from the unemployment stock (the flows are measured over the period) $)^{2}$.

Inflows $\left(\mathrm{I}_{\mathrm{t}}\right)=$ Quits + Fires + New Entrants

Outflows $\left(\mathrm{X}_{\mathrm{t}}\right)=$ New Hires + Retires, Deaths + New participants in Labour Market Programs.

In this format we can consider equilibrium as one where the inflows into unemployment just equal the outflows out of unemployment, that is, when the unemployment rate remains constant. Note, however, that this "equilibrium” unemployment rate is not unique and has no welfare significance.

It is useful to consider an analogy to demographic analysis: a stationary population has Unemployment constant, but a stable population has Unemployment constant and the duration distribution is constant. In a recession, unemployment inflows increase and unemployment outflows fall significantly. As such, the first impact of a recession could be a fall in the proportion of long term unemployment, but it subsequently increases provided the outflow rate remains constant or falls. Note that data on unemployment durations are for interrupted spells, hence we would expect that after the start of a recession the long durations would continue to increase. In demographic theory it has been shown that an increase in the birth rates (assuming the age specific mortality rates are unchanged) leads to a fall in the average age of the population. If the mortality rates fall (rise), ceteris paribus, then the average age of the population would gradually increase (decrease) until it reaches its new equilibrium level. Analogously, if there is an increase in the inflows into unemployment (and no change in the duration specific exit probabilities) then the average duration would fall, and an increase in the unemployment rate. If there was a fall (rise) in the exit probabilities but no change in the inflow rate, then there would be a permanent increase (decrease) in the average duration and the unemployment rate would also rise (decline). Machin and Manning

\footnotetext{
2 Note that in the literature on capital and investment, economists almost always try to estimate models of investment (the addition to capital stock, a flow) and not the level of the capital stock. However, for some reason, economists usually estimate equations for the stock of unemployment, partly because flow data are not easily available.
} 
(1998) have shown that a fall in the exit probabilities for any duration group leads to an increase in unemployment and hence an increase in long term unemployment.

The situation is somewhat different in a recession, since inflows and outflows deviate only temporarily from their prior values. In a typical recession, the inflows into unemployment increase for a short while, and then go back to their previous levels. At the same time, the exit probabilities fall and continue at low levels for a longer period of time. As such, we would expect the percentage of long term unemployment to fall temporarily before increasing subsequently for a few years. What we have learned from past recessions is that it sometimes takes a very long time for the unemployment rate to return to its pre-recession levels, see OECD (2009, pp. 36-38). Similarly, as the recession takes hold, long term unemployment increases and it can take an even longer time for long term unemployment to return to prerecession levels: sometimes the economies never return to previous levels before they are hit by another recession. Hence, the lesson we have to learn is to either prevent a recession (which is very difficult or impossible) or, perhaps more realistically, to prevent the recession from becoming too severe or lasting for too long. That requires not only appropriate (and timely) monetary and fiscal policies but also active labour market policies to help the long term unemployed to re-integrate into the labour market.

\section{A Schematic Presentation}

Here is a stylised account of a sequence of moves in a labour market responding to a sudden fall in aggregate demand for output (the actual response would also depend on whether the fall in demand is expected to be temporary or permanent):

(a) Firms stop new hires (outflows from unemployment fall). Since firms stop hiring workers, new entrants into the labour market are unable to find work and join the unemployment queue: inflows into unemployment increase.

(b) Firms cut back on over-time, and put workers on short time working (cut working hours)

(c) Casual workers are laid off (inflows into unemployment increase)

(d) Contract workers contracts are not renewed (inflows into unemployment increase)

(e) Permanent workers are laid off (inflows into unemployment increase)

(f) As hiring has stopped (or reduced dramatically) outflows fall and remain low for a long time, until demand for goods and services begins to increase. 
(g) As demand for goods and services pick up, firms increase the working hours of existing workers (no change in outflows)

(h) Firms increase over-time work (no change in outflows).

(i) Firms increase casual and contract workers (outflows increase).

(j) Firms, when demand has risen (and is expected to remain high) begin hiring new permanent workers, (outflows increase).

These are the moves of larger firms. Small firms are likely to move through items (a) through (d) very rapidly. Firms that become bankrupt due to a crisis would simply have to do all the items, (a) through (e) simultaneously.

In Figure 2, we show a stylised version of the inflows into unemployment and outflows from unemployment. As the recession hits at time $t_{0}$, the increase inflows and decrease in outflows would lead to an increase in unemployment. As the inflows return to a previous equilibrium level and outflows begin to increase, unemployment would continue to increase. Even after time $t_{1}$, if outflows reach the same level as inflows unemployment would continue to increase for some time before returning to its original equilibrium level.

Figure 2: Response of Inflows and Outflows to a Demand Shock

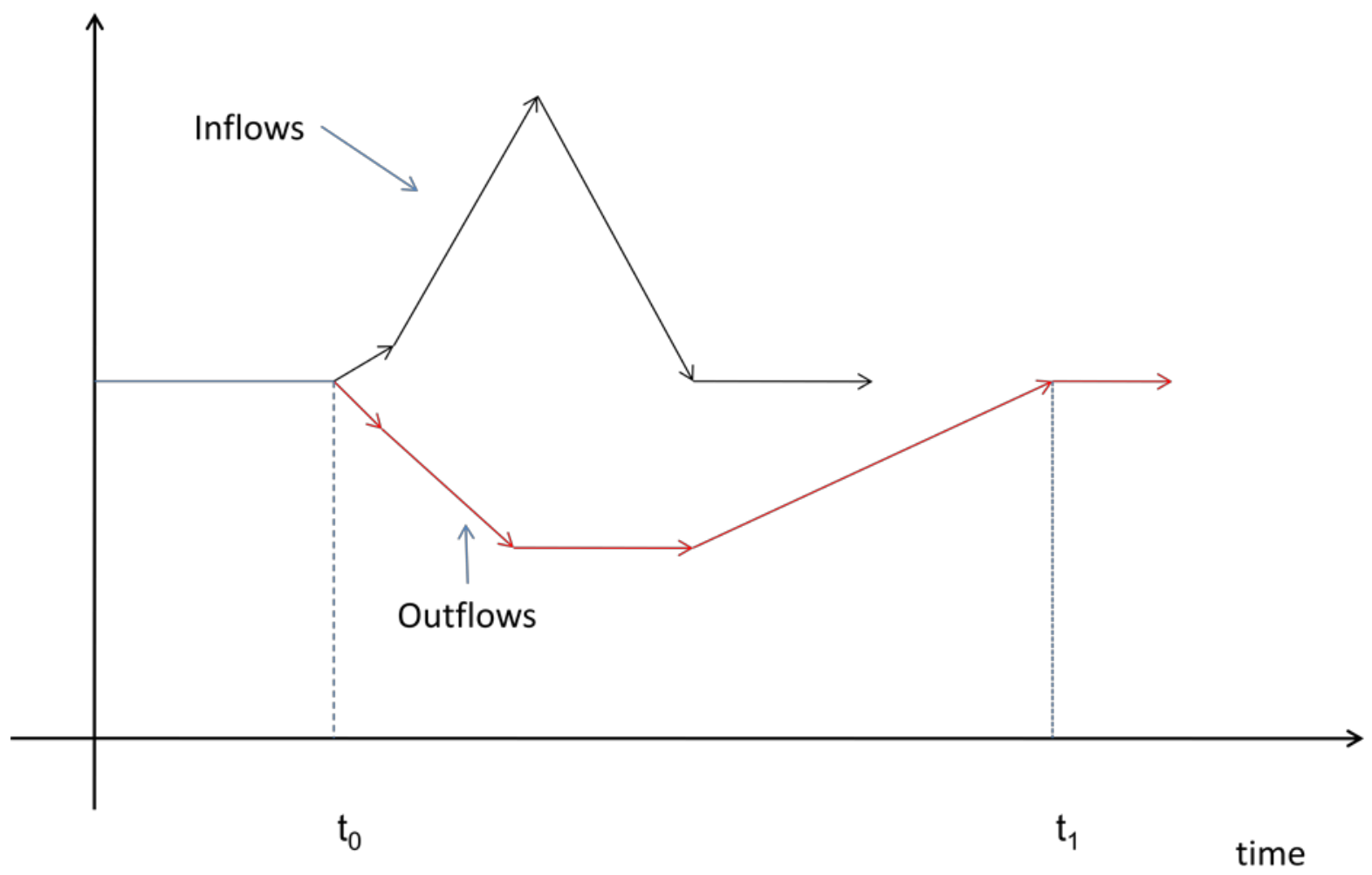


Thus the impact on the numbers employed is usually lagged behind a fall in demand by between six and twelve months. Usually, the employer would wait-and-see if the fall in demand is more than a temporary fall because the employer does not wish to lose the skilled and loyal staff s/he has been employing for some time.

The impact of the increase in inflows into unemployment is to decrease the probability of each of the unemployed from finding work (even if the level of demand for labour went back to its previous levels): for each job vacancy there are more potential applicants. As a result, some of the unemployed will now be unemployed for a longer duration: those previously unemployed for less than a month will now move onto the next group of one to three months duration, and like a pack of dominoes falling there will be more unemployed workers shifted onto the next duration level, etc. A generally accepted definition of long term unemployment is one where a worker has a continuous period of unemployment of 12 months or longer. In the USA, their definition of long term unemployment is for workers of 6 months or longer of unemployment duration ${ }^{3}$.

Whether a person leaves the unemployment stock or the long term unemployment stock depends on the following:

(a) Job vacancies for particular kinds of workers: with particular levels of education, skills, experience, occupation, and geographical location. Many statistical agencies report vacancy rates: numbers of vacancies advertised by employers. However, unless there are data of vacancies by skill levels etc, the aggregate series is not very useful.

(b) Given there are vacancies, do the unemployed workers discover these vacancies? That depends to some extent on the search strategies (process) followed by the unemployed workers. The search intensity (how often a worker looks for work) and efficiency of job search would influence the unemployed finding a vacancy.

(c) Given that a worker finds a vacancy and meets an employer, whether the "match" is successful depends on the vector of characteristics the employer seeks and the characteristics of the applicant. There is some evidence to suggest that employers use the duration of unemployment of the applicant as a signal of the quality of the worker.

\footnotetext{
${ }^{3}$ In the USA, unemployment benefits were usually limited to six months. However, in the Great Recession unemployment benefits have been extended to up to 18 months. The maximum duration climbed to 99 weeks in early 2009 and will remain at that level until at least the end of 2011.
} 
Hence, those who have been unemployed for long periods find it increasingly difficult to find work.

(d) If the job applicant receives a job offer, noting that during a period of high unemployment that there are many applicants for each vacancy, whether s/he accepts the offer depends not only on the wage offer (relative to the reservation wage of the unemployed job searcher), but also on other conditions of employment affecting the quality of job offered. The reservation wage would be influenced by the "generosity" (and duration) of unemployment benefits. A factor that would have been especially important in the Great Recession would also be the amount of accumulated savings that the unemployed person has, as well as the level of mortgage payments and other personal debts ${ }^{4}$. The Global Financial Crisis and the bursting of the housing price bubble meant that many people who had their assets tied up in stock market equity and/or housing would suddenly have become poorer. In the USA, many home owners with substantial mortgages would presumably accept almost any job, if it were available. The quality of a job that an unemployed person would accept would also depend on their age and experience: a person who had worked in senior positions for a long time would be unlikely to accept a job at a lower occupational level. For example, if a Wall Street Banker was offered a clerical position s/he is unlikely to accept the position. Often most of the vacancies that are available are for people with reasonable levels of education and skills, while many of the unemployed are those with low levels of education and unskilled workers. In general, the longer the worker has been unemployed, the lower his or her expectations about the wage they would accept and/or the quality of job that they would accept. Similarly, in a major recession the unemployed workers would have low expectations of getting many wage offers and are likely to have a very low reservation wage or reservation quality. Again there is evidence to suggest that unemployed workers who eventually find work accept significantly lower wages, see Jacobson, LaLonde, and Sullivan (1993), Couch and Placzek (2010).

(e) Although it is often argued that the generosity (and duration) of unemployment benefits leads to workers refusing job offers and hence leading to higher levels of unemployment and long term unemployment, it should be noted that from a societal

\footnotetext{
${ }^{4}$ It would be interesting to carry out research to see if the value of personal assets and debts influence exit probabilities of the unemployed.
} 
point of view an unemployed person who accepts a lower quality job (that is a job that requires less education, skills, or experience than the worker has) means a "poor match” and hence is not socially efficient. In a paper by Mark Stewart (2007) using longitudinal data from the British Household Panel Survey (BHPS), he finds that a low wage job has as large adverse effect as unemployment on future prospects. Evidence provided in Butterworth et al. (2011) shows that the mental health of an unemployed person who moves to a job with poor "psychosocial" quality worsens. Hence, labour market policies that encourage an unemployed person to accept any job is likely to lead to a decrease in the welfare of the unemployed, as well as societal welfare.

(f) However, from an aggregative point of view, unemployment benefits act as an automatic stabiliser and hence increase aggregate demand and hence the probability of job offers.

The long term unemployed usually have a lower exit probability compared to other job seekers for one of two reasons: firstly, the employers often treat unemployment duration as a negative signal $^{5}$ (they must be hopeless, that is why they are long term unemployed); secondly, the long term unemployed lose their skills (skill atrophy/human capital depreciation), become dejected and drop out of the labour market.

There is a well known analogy for the long term unemployed: it is the Flower shop analogy, customers buy the freshest flowers, and the wilted flowers are left in the shop. When new flowers arrive, the old flowers look even worse the next day. Employers hire the newly unemployed workers, and the long term unemployed remain in the unemployed stock. When a new inflow of unemployed workers enter the stock, the long term unemployed are pushed to the end of the queue. Thus the long term unemployed have lower and lower probabilities of finding employment.

\section{The Great Recession: Unemployment and Long Term Unemployment}

In this section we present evidence on the growth of unemployment and long term unemployment in the Great Recession. As mentioned in the introduction, unemployment in

\footnotetext{
${ }^{5}$ A New York Times article headed "The Unemployed Need Not Apply" (February 19, 2011) reports that at a forum of the Equal Opportunities Commission several people mentioned that employers were not willing to consider unemployed applicants and that it discriminated against (especially) African Americans who constitute a large proportion of the unemployed. Similarly, a report in Management Today $\left(21^{\text {st }}\right.$ February 2011) says that a survey by Barclays Corporate and the Financial Times that $57 \%$ of employers are not willing to consider ex-civil servants.
} 
the OECD went up from 30.6 million to 47 million from 2007 Q4 to 2010 Q2, while long term unemployed persons went up from 8.5 million to 14.9 million, Table 1 and Figure 3. Or looking at the percentage increases, there was an increase of 53.8 percent in the numbers unemployed and a 75.8 percent increase in the long term unemployed. This Table shows that even in aggregate, that at the onset of the recession as unemployment increases that the percentage of long term unemployment first decreases (due to the increase in inflows with short durations), but after some time the percentage of long term unemployment increases (as the outflows from unemployment fall due to a fall in exit probabilities). For this aggregate level OECD data, it appears that there is actually a fall in the numbers of long term unemployed (NLTU) which is perhaps due to country wide differences (e.g. in Germany unemployment and long term unemployment were falling). The numbers of long term unemployed (NLTU) appear to lag behind the increase in unemployed numbers by about three quarters. However, the Proportion of Long Term Unemployment (PLTU) first falls and then after about 6 quarters starts increasing. These are simply average relationships that will be discussed in more detail when we turn to the heterogeneity in response for different countries during the Great Recession. This massive growth of unemployment and long term unemployment was very unevenly distributed across the OECD countries. For the G7 countries, the increase was a "modest" increase of 80.3 percent over the same period. 
Table 1: The Growth of Unemployment and Long Term Unemployment in the OECD

\begin{tabular}{|c|c|c|c|}
\hline & $\begin{array}{c}\text { OECD } \\
\text { Unemployed } \\
\text { (000s) }\end{array}$ & $\begin{array}{c}\text { OECD NLTU } \\
\text { (000s) }\end{array}$ & PLTU (\%) \\
\hline 2007.75 & 30600.16257 & 8507.74779 & 27.8 \\
\hline 2008 & 32308.37721 & 8359.65363 & 25.9 \\
\hline 2008.25 & 32462.27471 & 8214.99698 & 25.3 \\
\hline 2008.5 & 33238.14933 & 8022.37502 & 24.1 \\
\hline 2008.75 & 36587.03358 & 8660.95554 & 23.7 \\
\hline 2009 & 44407.14378 & 9511.84374 & 21.4 \\
\hline 2009.25 & 46479.92846 & 10390.00102 & 22.4 \\
\hline 2009.5 & 46683.41369 & 11435.76552 & 24.5 \\
\hline 2009.75 & 46542.97212 & 12691.31663 & 27.3 \\
\hline 2010 & 49809.08832 & 14726.26313 & 29.6 \\
\hline 2010.25 & 47262.65189 & 14984.66126 & 31.7 \\
\hline 2010.5 & 40011.72493 & 13688.74387 & 34.2 \\
\hline & & & \\
Increase 2007 \\
Q4 to 2010 Q3 & 9411.56236 & 5180.99608 & 6.4 \\
\hline $\begin{array}{c}\text { \% Increase } \\
\text { 2007 Q4 to } \\
\text { 2010 Q3 }\end{array}$ & & & \\
\hline
\end{tabular}

Source: OECD Unemployment duration by gender and age groups_New.xls 
Figure 3: OECD Unemployment, Long Term Unemployment (NLTU), and Proportion of LTU (PLTU)

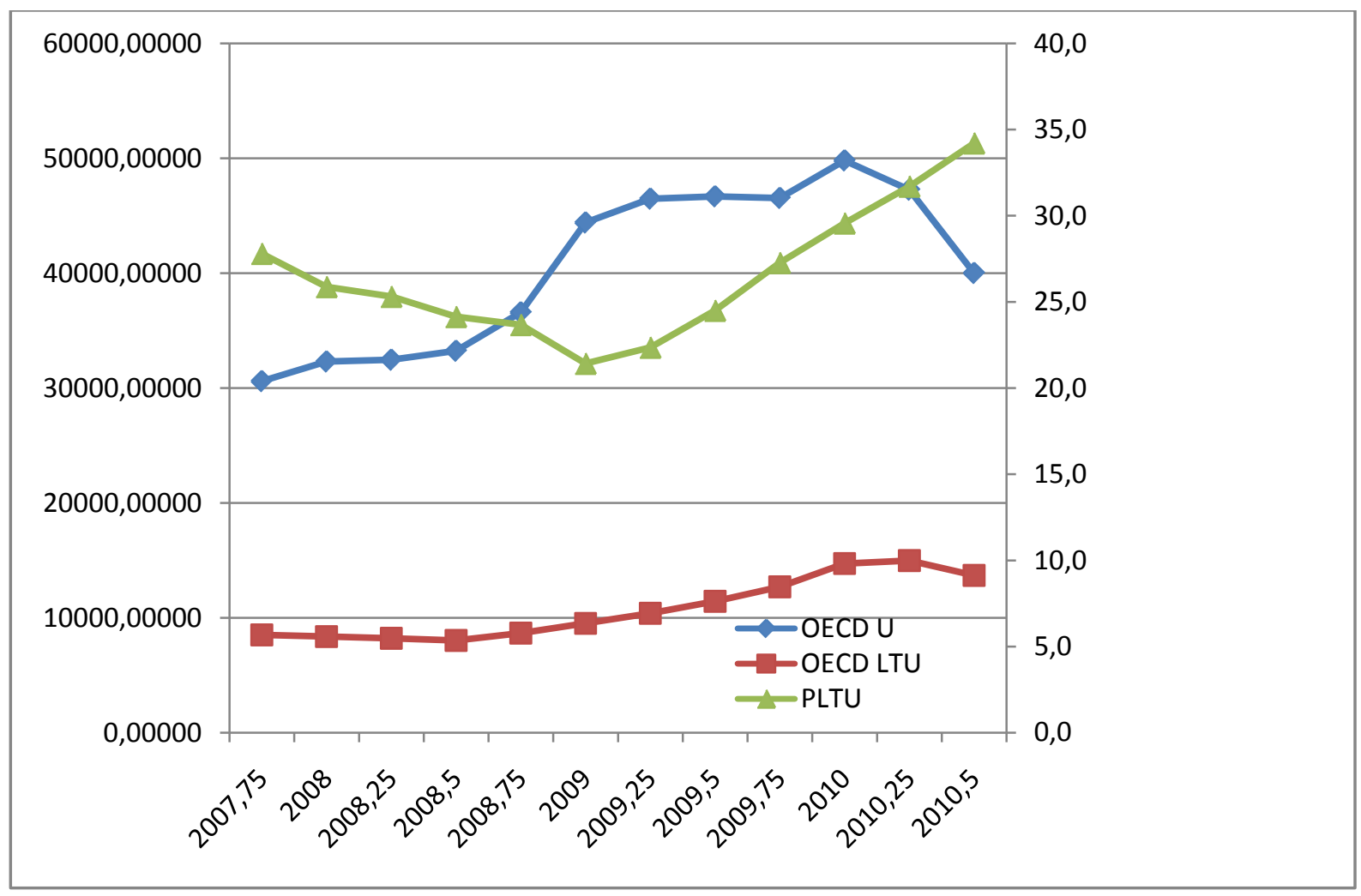

Source: OECD Unemployment duration by gender and age groups_New.xls

Table 2 shows that the growth of unemployment in the OECD was also unevenly distributed, with Ireland, Spain, and the USA leading with the highest increases in the unemployment rate. In many countries in the OECD unemployment did not rise as much as in previous recessions because of the decreases in average hours worked, with some countries using short time working schemes, e.g. Germany (kurzarbeit scheme), Japan and Canada ${ }^{6}$. Since in previous years growth had been strong, firms wished to retain their skilled labour.

\footnotetext{
${ }^{6}$ See OECD(2010b) Working Paper No. 756
} 
Table 2: Unemployment Rates in the Great Recession

\begin{tabular}{|c|c|c|}
\hline & $\begin{array}{l}\text { Increase in UR } \\
\% \text { points }\end{array}$ & \% Increase in UR, 2007 Q4-2010 Q2 \\
\hline AUS UR & 0.8 & 18.2 \\
\hline AUT UR & 0.5 & 12.2 \\
\hline BEL UR & 1.3 & 18.1 \\
\hline $\begin{array}{l}\text { CAN } \\
\text { UR }\end{array}$ & 2.1 & 35.6 \\
\hline CZE UR & 2.4 & 49.0 \\
\hline DEU UR & -1.1 & -13.8 \\
\hline $\begin{array}{l}\text { DNK } \\
\text { UR }\end{array}$ & 3.9 & 114.7 \\
\hline ESP UR & 11.4 & 132.6 \\
\hline FIN UR & 1.9 & 28.8 \\
\hline FRA UR & 2 & 25.3 \\
\hline GBR UR & 2.7 & 52.9 \\
\hline GRC UR & 4.2 & 52.5 \\
\hline $\begin{array}{l}\text { HUN } \\
\text { UR }\end{array}$ & 3.4 & 43.0 \\
\hline IRL UR & 8.7 & 181.3 \\
\hline ITA UR & 2.1 & 33.3 \\
\hline JPN UR & 1.3 & 33.3 \\
\hline $\begin{array}{l}\text { MEX } \\
\text { UR }\end{array}$ & 1.8 & 48.6 \\
\hline NLD UR & 1.2 & 36.4 \\
\hline $\begin{array}{l}\text { NOR } \\
\text { UR }\end{array}$ & 1.1 & 44.0 \\
\hline NZL UR & 3.4 & 97.1 \\
\hline POL UR & 1 & 11.6 \\
\hline PRT UR & 3.1 & 39.2 \\
\hline SVK UR & 3.7 & 34.6 \\
\hline SVN UR & 2.6 & 55.3 \\
\hline $\begin{array}{l}\text { SWE } \\
\text { UR }\end{array}$ & 2.6 & 43.3 \\
\hline TUR UR & 1.5 & 16.5 \\
\hline USA UR & 4.9 & 102.1 \\
\hline
\end{tabular}

Source: OECD Harmonised Unemployment Rates 
Figure 4: Unemployment Rates in the G7

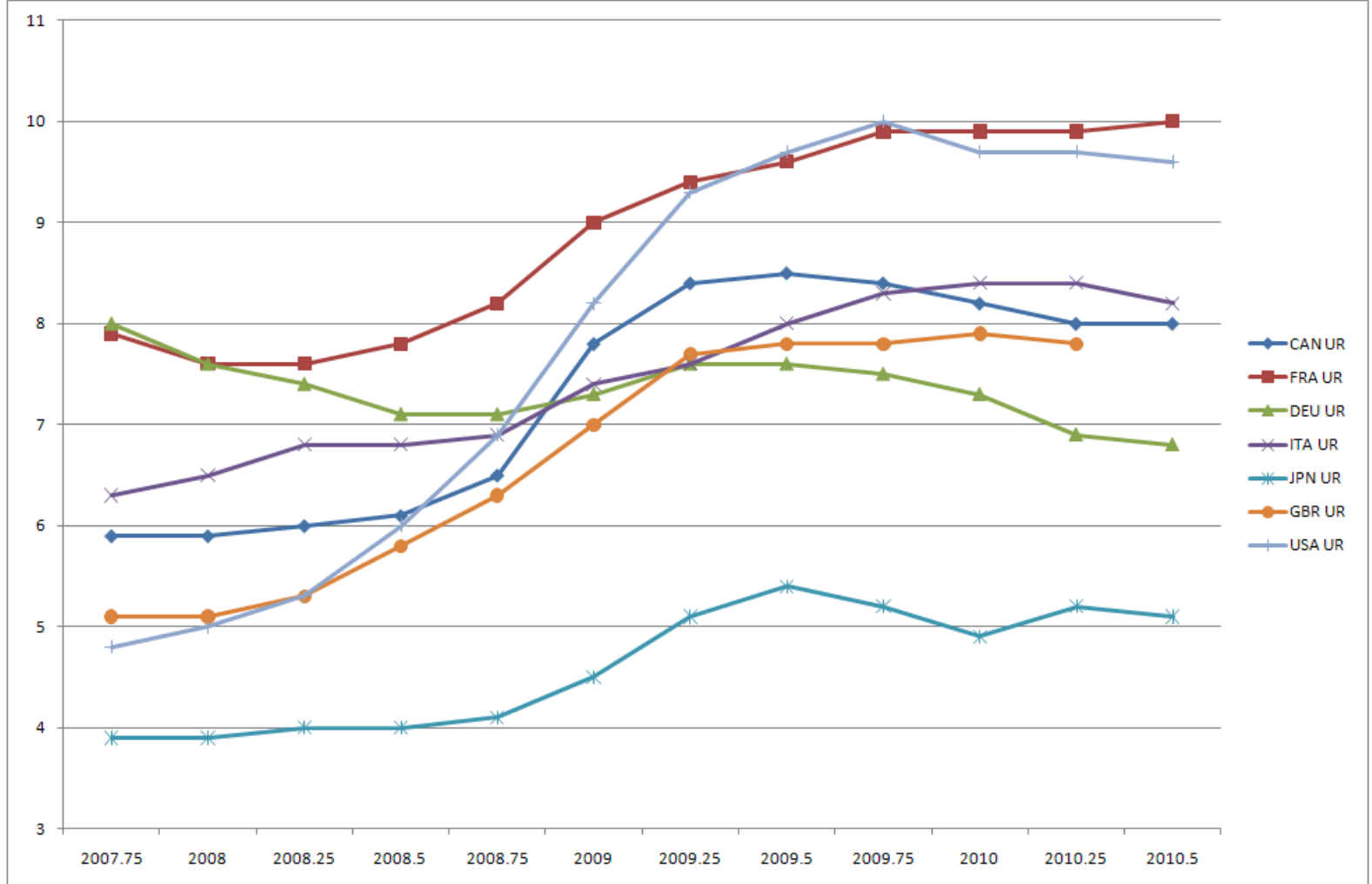

As Figure 4 shows unemployment rates in all the G7 countries were rising, except for Germany, and this is reflected in the increases in the percentage of long term unemployment in the G7 countries (except for Germany). A simple correlation between the percentage increase in unemployment rates and the percentage increase in the PLTU is 0.82 (over this period). Of course, if we looked at the first few quarters of the recession, we would probably have a lower and negative correlation.

During a recession, as discussed earlier, labour force participation rates are likely to fall as people give up looking for work as their experience of rejections of applications increase (discouraged worker hypothesis). On the other hand, during a recession more people may join the labour force to compensate for the loss of work by a family member (added worker hypothesis). As we see in Figure 5, the Labour Force Participation Rates may then rise or fall depending on these two offsetting forces. In the Great Recession, Labour Force Participation Rates went down marginally in Canada, Italy, Japan, New Zealand and the USA (USA had the largest fall of 1.06 percentage points), and went up or remained constant in the other countries. 
In the Great Recession, Employment Rates (see Figure 6) went down in all the above countries, except in Germany where they went up. The biggest fall was in Spain followed by the USA. This reflects the increases in unemployment and fall in labour force participation rates.

Figure 5: Labour Force Participation Rates in 2007 Recession

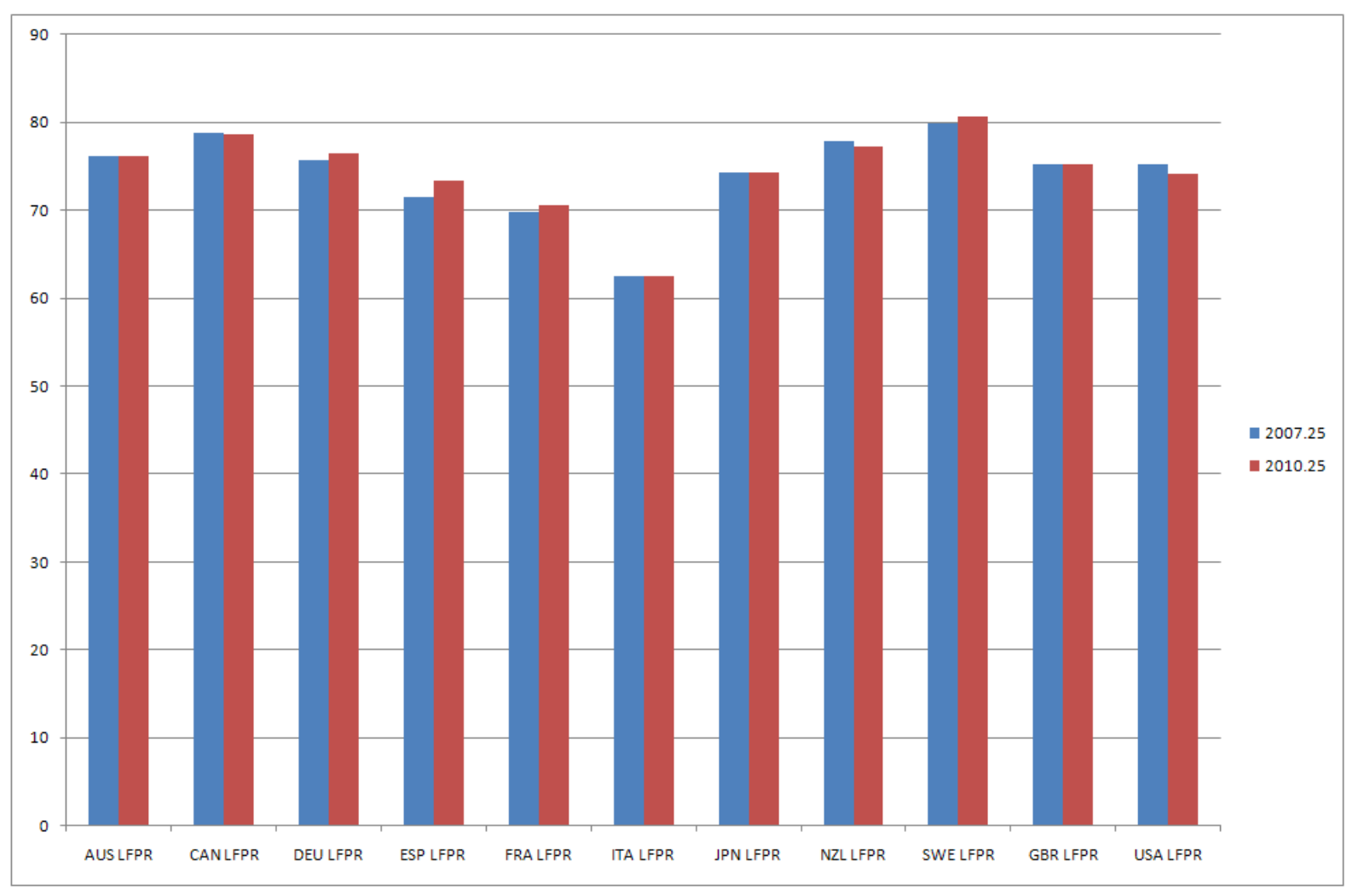

Source: OECD Quarterly Labour Force Statistics 
Figure 6: Employment Rates in 2007 Recession

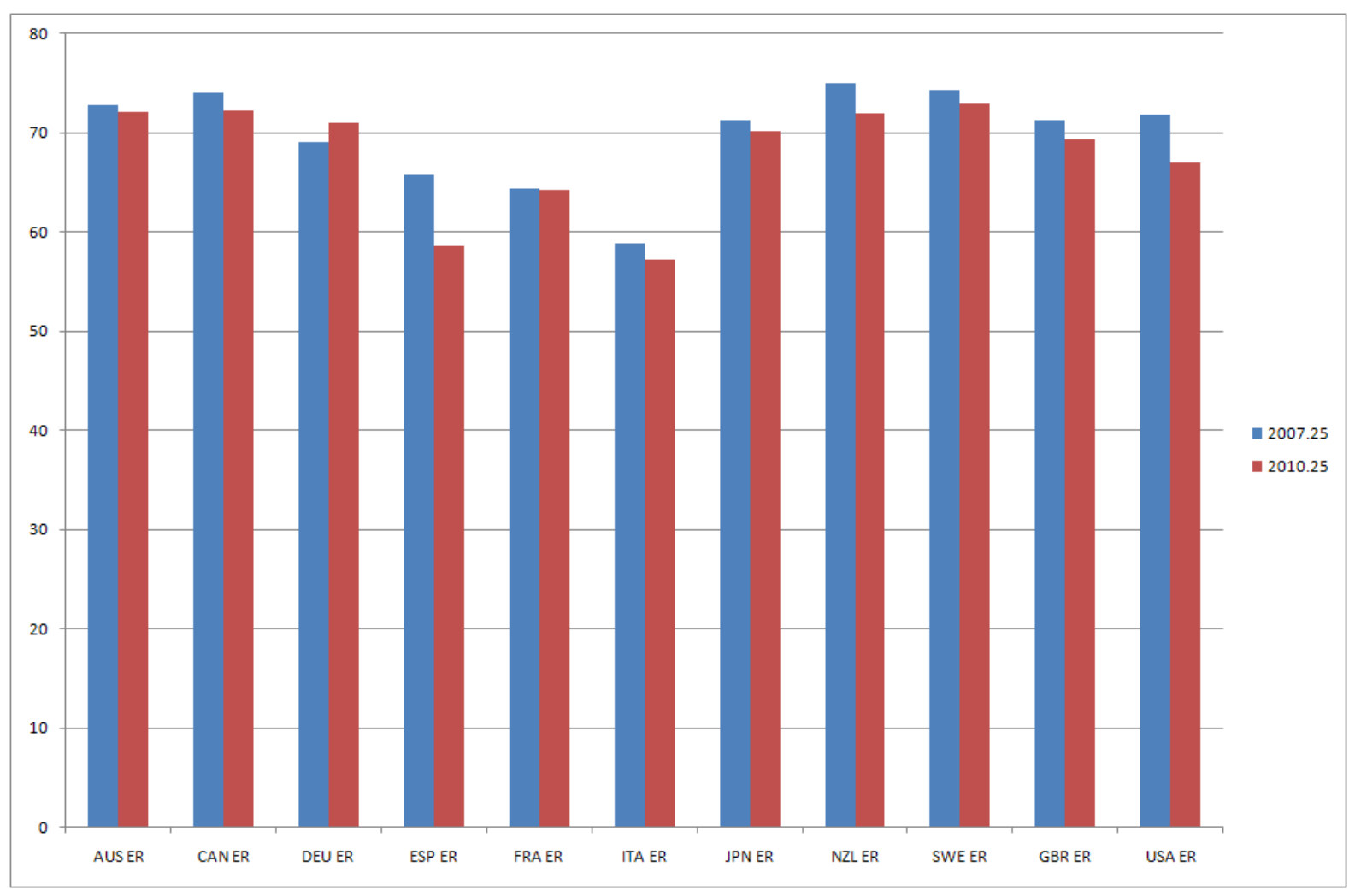

Source: OECD Quarterly Labour Force Statistics 
Table 3: The Growth in Long Term Unemployment in OECD Countries (2007 Q4-2010 Q3)

\begin{tabular}{|c|c|c|c|}
\hline & $\begin{array}{l}\text { Percentage } \\
\text { Increase in } \\
\text { NLTU, 2007 } \\
\text { Q4-2010 Q3 }\end{array}$ & $\begin{array}{l}\text { Percentage } \\
\text { Point } \\
\text { Increase in } \\
\text { PLTU, 2007 } \\
\text { Q4-2010 Q3 }\end{array}$ & $\begin{array}{l}\text { Percentage } \\
\text { Increase in } \\
\text { PLTU, 2007 } \\
\text { Q4-2010 Q3 }\end{array}$ \\
\hline AUS & 67.4 & 4.5 & 31.6 \\
\hline AUT & 7.4 & -1.3 & -5.2 \\
\hline BEL & 18.6 & -3.0 & -5.8 \\
\hline CAN & 139.6 & 4.0 & 53.1 \\
\hline CZE & 31.1 & -5.6 & -11.4 \\
\hline DEU & -32.0 & -9.6 & -16.9 \\
\hline DNK & 227.2 & 5.8 & 39.9 \\
\hline ESP & 357.9 & 18.0 & 93.0 \\
\hline EST & 307.8 & 4.1 & 8.4 \\
\hline FIN & 51.1 & 5.4 & 24.5 \\
\hline FRA & 32.7 & 3.4 & 9.0 \\
\hline GBR & 115.0 & 8.0 & 32.6 \\
\hline GRC & 46.5 & -3.3 & -6.6 \\
\hline HUN & 67.3 & 7.9 & 17.8 \\
\hline IRL & 408.9 & 21.5 & 76.6 \\
\hline ISL & 935.3 & 13.3 & 207.1 \\
\hline ITA & 24.1 & 4.6 & 10.2 \\
\hline JPN & -100.0 & -34.5 & -100.0 \\
\hline LUX & 10.8 & -0.1 & -0.4 \\
\hline MEX & -100.0 & -1.2 & -100.0 \\
\hline NLD & 9.1 & -10.9 & -28.4 \\
\hline NOR & 105.2 & 4.2 & 24.8 \\
\hline NZL & 221.9 & 2.9 & 68.8 \\
\hline POL & -25.1 & -16.2 & -33.3 \\
\hline PRT & 57.9 & 6.5 & 13.9 \\
\hline SVK & 21.9 & -8.5 & -11.4 \\
\hline SVN & 67.3 & 4.8 & 11.6 \\
\hline SWE & 87.4 & 3.9 & 27.0 \\
\hline TUR & 35.1 & 1.7 & 6.9 \\
\hline USA & 532.8 & 20.9 & 234.8 \\
\hline
\end{tabular}

Source: OECD Unemployment duration by gender and age groups_New.xls 
Table 3 shows the growth in long term unemployment for the different countries of the OECD during the Great Recession. Table 4 shows that the countries hit hardest in the OECD (in terms of the percentage increase in the numbers of long term unemployed, NLTU) were the Iceland, USA, and Ireland. In terms of the percentage point increase in the proportion of long term unemployed, the countries that were hardest hit were Ireland, the USA, and Spain. In terms of the percentage increase in the Proportion of Long Term Unemployment (PLTU), the hardest hit were the USA, Iceland and Spain. Although the USA has had a very large increase in long term unemployment, the proportion of long term unemployment in the USA is just beginning to reach the levels common in European countries. A simple correlation between the percentage increase in unemployment rate and the percentage increase in the proportion of long term unemployment is 0.67 .

Table 4: Increases in Long Term Unemployment-The Top Five Countries

\begin{tabular}{|c|c|c|}
\hline $\begin{array}{l}\text { Percentage } \\
\text { Increase in NLTU, } \\
\text { 2007 Q4-2010 Q3 }\end{array}$ & $\begin{array}{l}\text { Percentage Point } \\
\text { Increase in PLTU, } \\
\text { 2007 Q4-2010 Q3 }\end{array}$ & $\begin{array}{l}\text { Percentage } \\
\text { Increase in PLTU, } \\
\text { 2007 Q4-2010 Q3 }\end{array}$ \\
\hline ISL & IRL & USA \\
\hline USA & USA & ISL \\
\hline IRL & ESP & ESP \\
\hline ESP & ISL & IRL \\
\hline EST & GBR & NZL \\
\hline
\end{tabular}

Source: OECD Unemployment duration by gender and age groups_New.xls 
Figure 7: Long Term Unemployed Persons, NLTU (000s) in the G7 Great Recession, 2007 Q4 to 2010 Q2 (Q3))

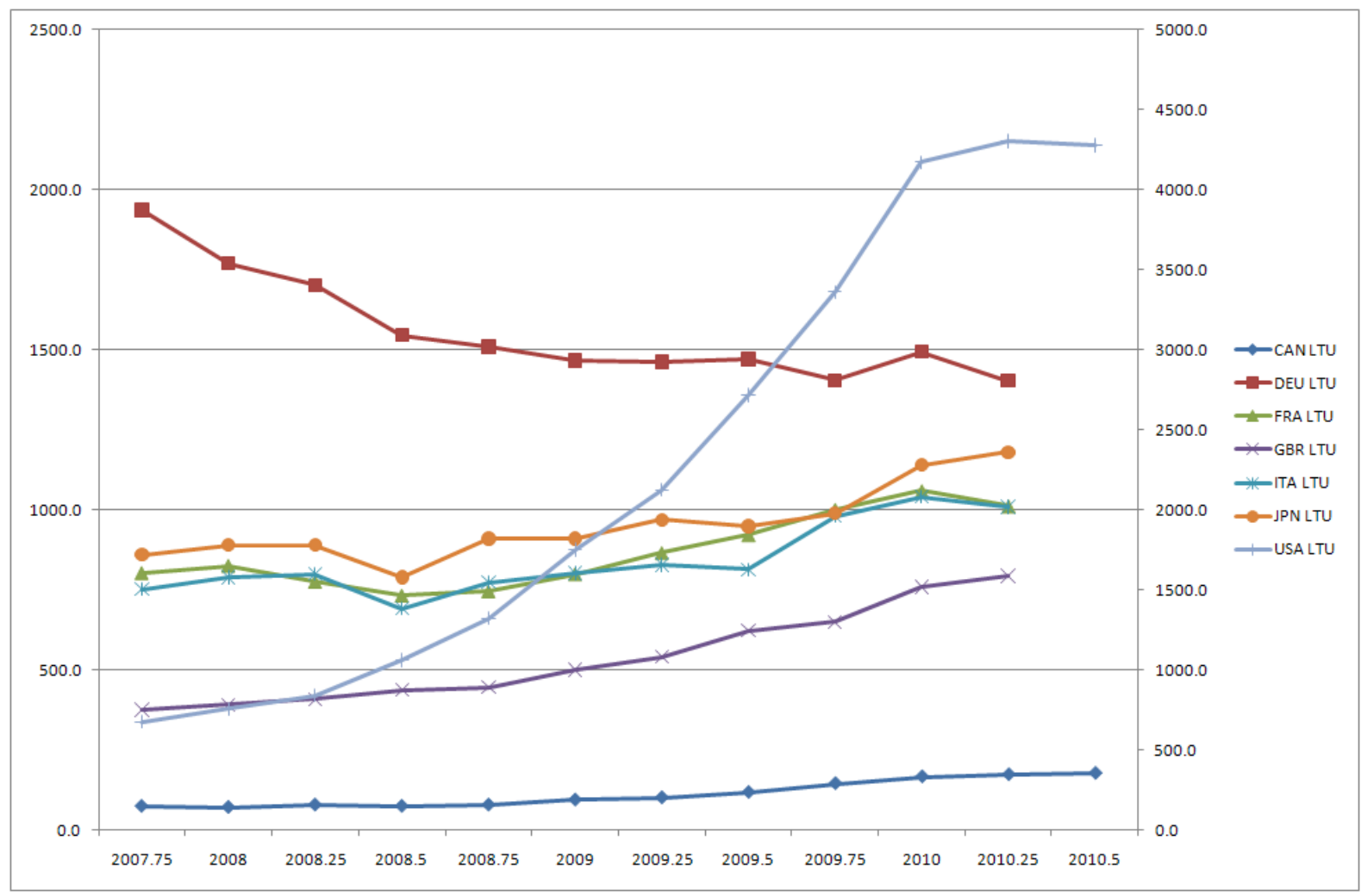

Source: OECD Unemployment duration by gender and age groups_New.xls Note: USA data (000s) are presented on the right hand scale.

As mentioned earlier, there is a great variety of experience of long term unemployment in the OECD. If we focus on the G7 countries, Figure 7 clearly shows that the numbers in long term unemployment (NLTU) increased for most of the G7 with a striking increase for the USA, but an almost continuous fall in the case of Germany. 
Figure 8: Proportion of Long Term Unemployment in total unemployment, the G7 countries, Great Recession, 2007 Q4 to 2010 Q2 (Q3)

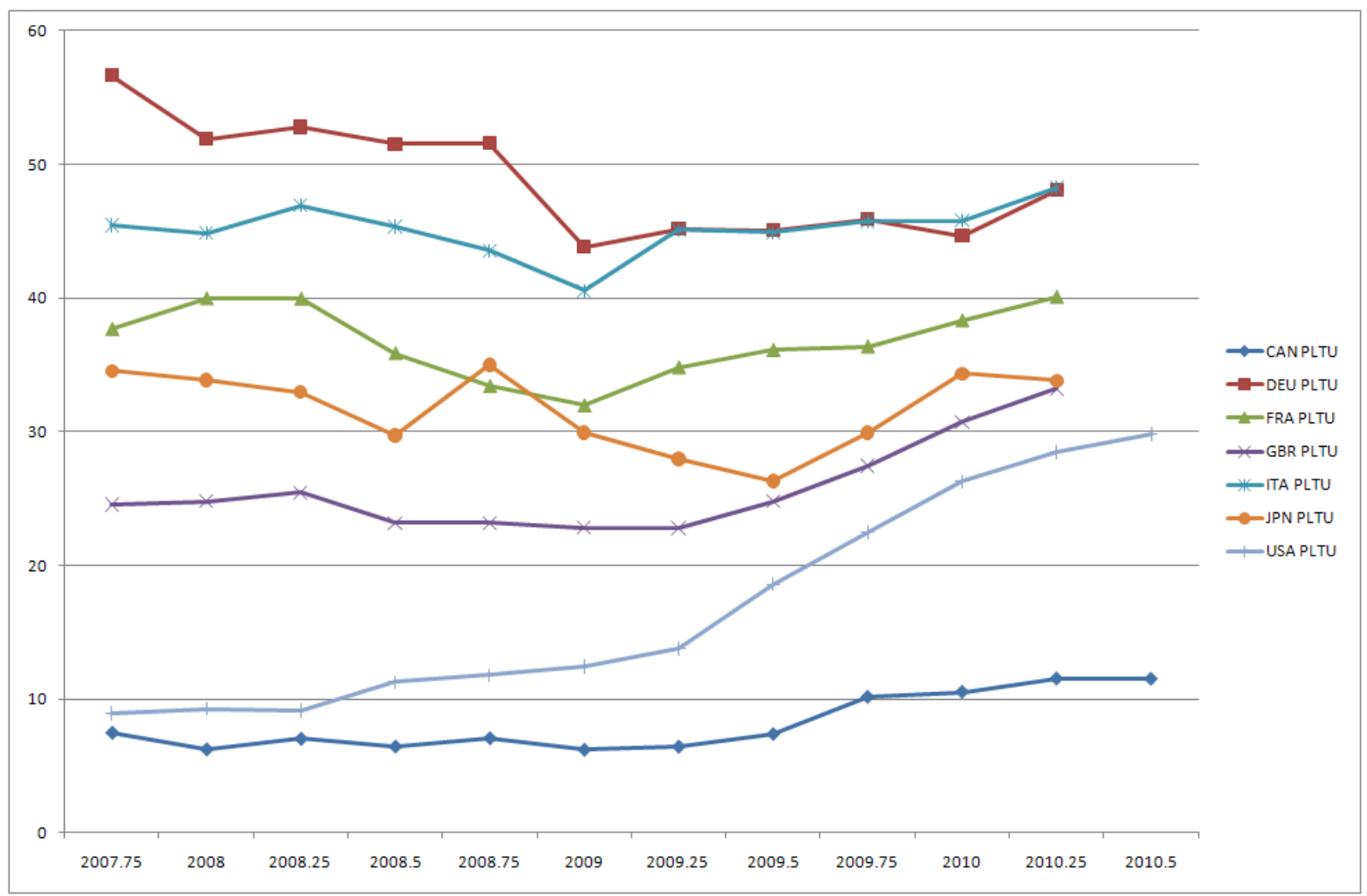

Source: OECD Unemployment duration by gender and age groups_New.xls

Figure 8 shows that the proportion of long term unemployment (PLTU) first falls during a recession (as increased inflows into unemployment generate a rapid increase in newly unemployed workers) and then grows larger as the recession progresses (and lower outflows from unemployment gradually translate into longer average spells of joblessness). In Germany, unemployment rates first fell and then increased in 2009 briefly before coming down again, but the PLTU first came down and then increased slightly until the end of the period. In Germany there was a declining trend in unemployment and long term unemployment, perhaps due to labour market reforms (Hartz Reforms) prior to the Great Recession. Although German long term unemployment fell over this period, the levels of long term unemployment are higher than in most of the G7 countries (except for Italy). In general, the PLTU lags behind increases in the unemployment rate. As we are still in the early stages of the recovery, it is expected that PLTU would continue to increase in many countries over the next few quarters. 
Let us now turn to the impact of the Great Recession on the workers of different ages. During a recession as the unemployment rate increases, there is usually a large increase in the unemployment of young people: firstly, because many of them are new entrants into the labour market, secondly, because the young have less work experience and skills and often work in casual or temporary jobs, thirdly, because many young people voluntarily quit their jobs to find a better job (they are more mobile) but then find it difficult to find a job in a recession. Once unemployed, older unemployed workers generally have a lower probability of finding work than younger job seekers, either due to employer discrimination or because the older workers are likely to be more "choosy" about accepting jobs which are below their experience levels.

Figure 9 shows that since there are a large group of people in the prime age group, not surprisingly, they dominate the shares of the long term unemployed.

Figure 9: Shares of Increase in numbers in Long Term Unemployment by Age,

\section{Great Recession}

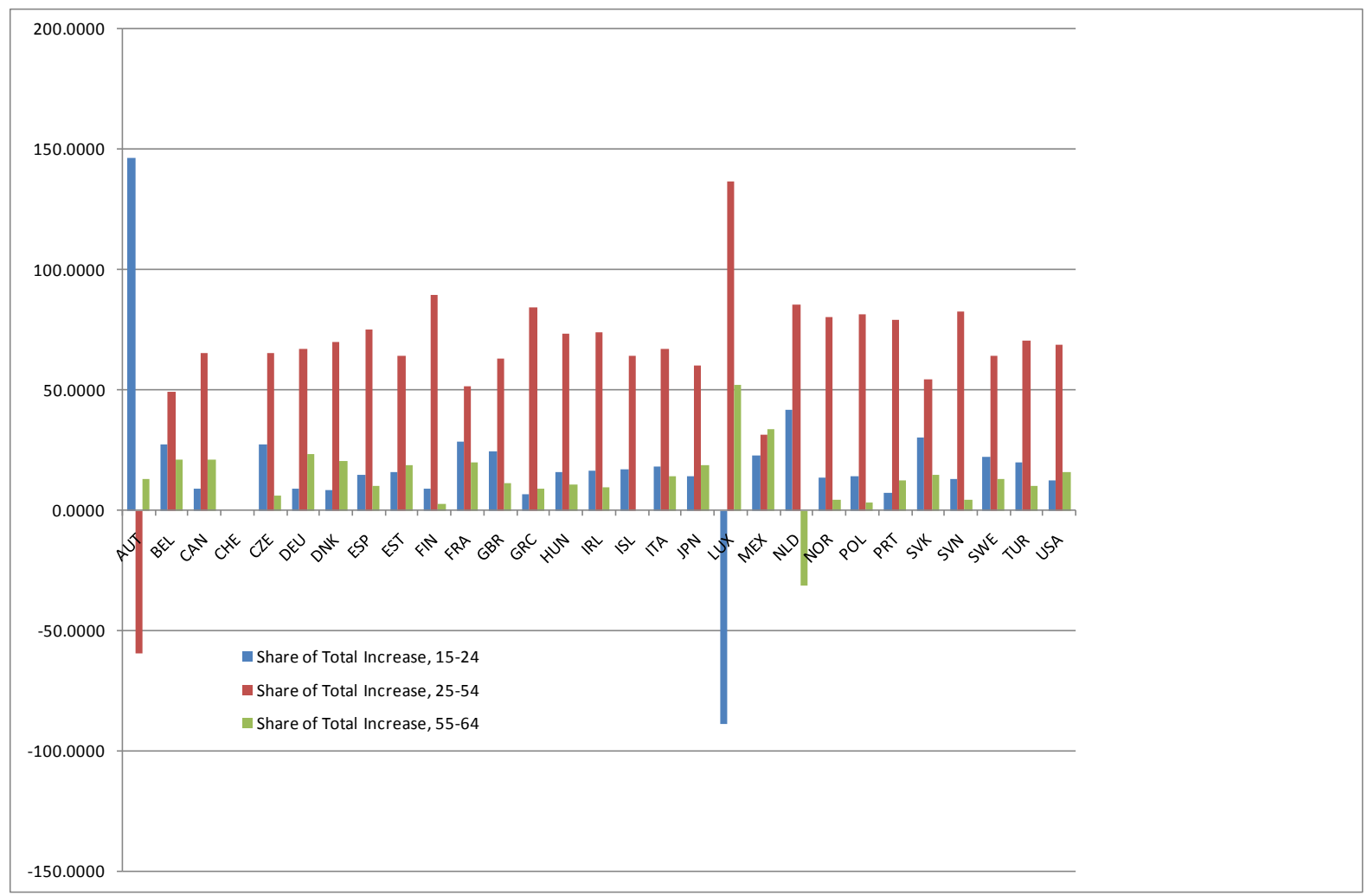

Source: OECD Unemployment duration by gender and age groups_New.xls 


\section{Figure 10: Percentage Increases in NLTU by Age in Great Recession}

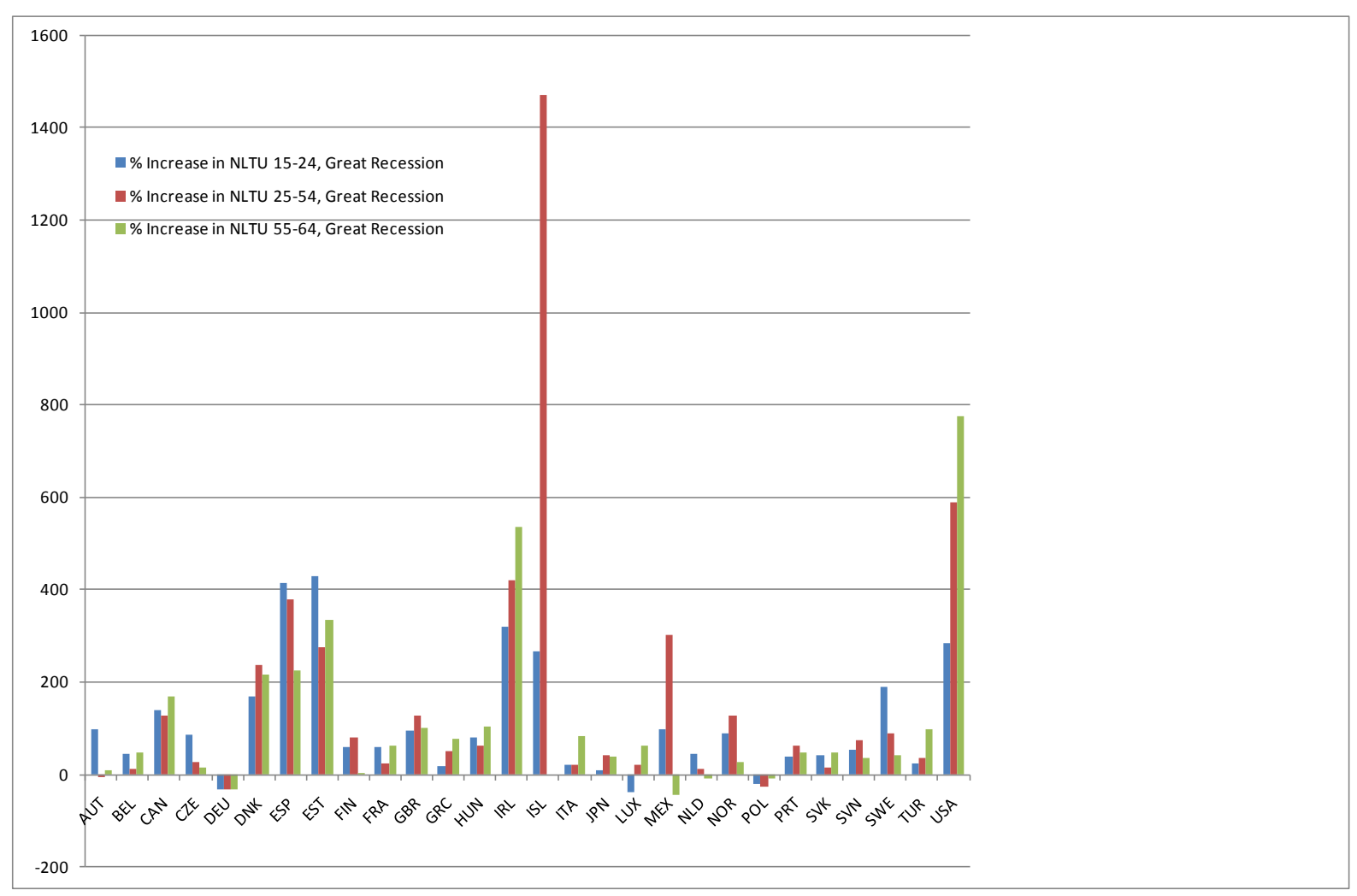

Source: OECD Unemployment duration by gender and age groups_New.xls

If we now turn to the impact of the Great Recession on the gender distribution we see that in many countries the male share of long term unemployment increased during the Great Recession. However, in some cases the male share fell, e.g. in Canada and New Zealand. In the G7 countries males dominate the long term unemployed, where the male share was less than fifty percent before the recession but increased by 2010 to over fifty percent. During this recession, as in many recessions, the industries that are hit hardest by unemployment tend to be manufacturing and construction. In these industries, males dominate in employment so we would expect the recession to hit males harder than women. It appears that for the G7 countries that is true, however, for some of the other OECD countries, especially Canada and New Zealand the share of males in long term unemployment declined over this period ${ }^{7}$. It is often argued that women are more likely to drop out of the labour force during a period of unemployment but this is not supported by the evidence of the recent recession.

\footnotetext{
7 This is an interesting finding that needs further research. It is possible that emigration from these countries provides a safety valve: the New Zealanders migrating to Australia.
} 
Figure 11: Male Share of Long Term Unemployment, Great Recession

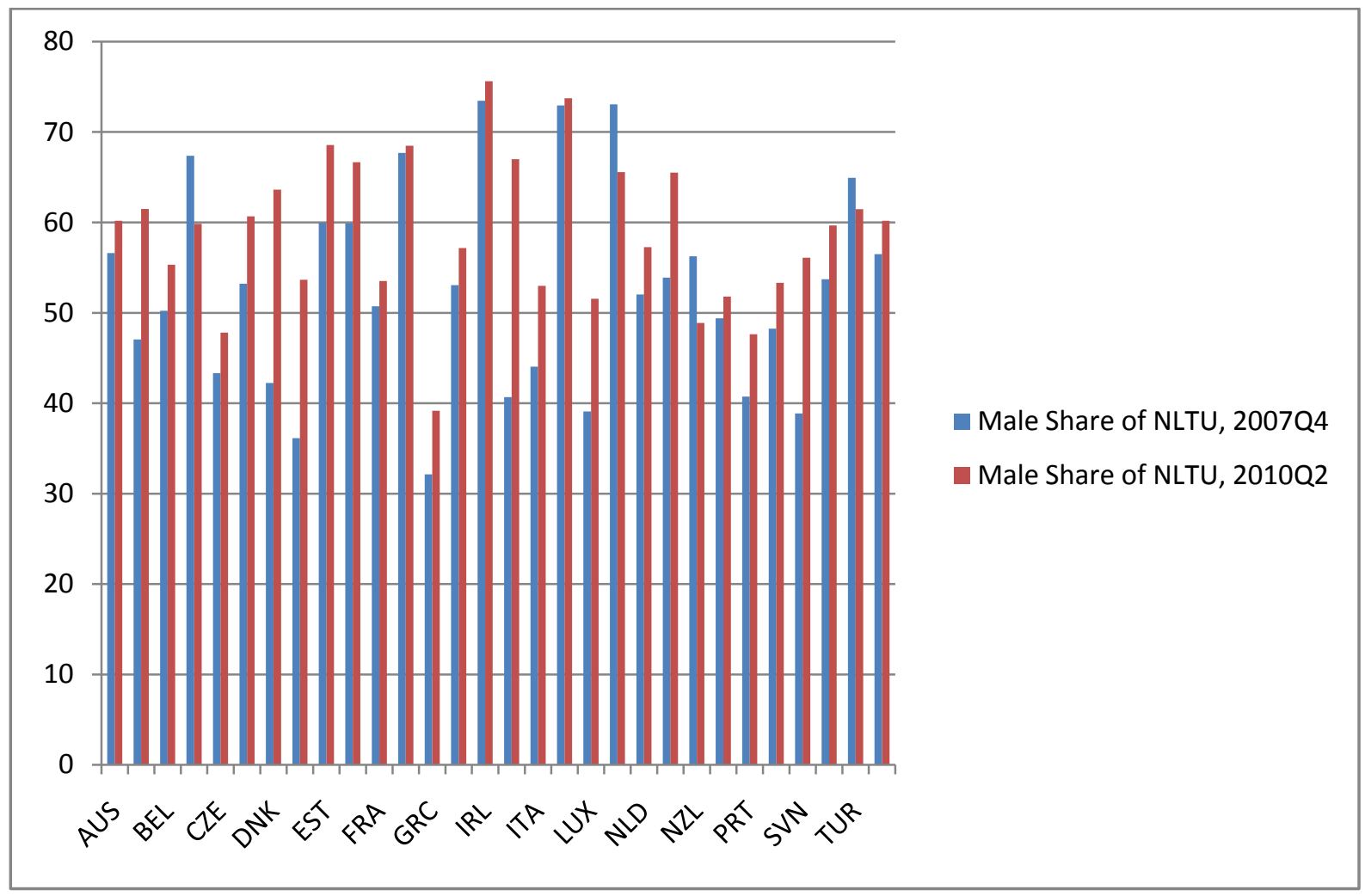

Source: OECD Unemployment duration by gender and age groups_New

\section{A Comparison of the Great Recession with some previous recessions}

In this section we compare the growth of long term unemployment in the Great Recession with earlier recessions and provide a descriptive account. In a subsequent section, we provide an analytical explanation of the differences. Although some countries were hit by a recession in 2001, most countries were unaffected by it. Figure 12 shows a graph of the unemployment rates and Figure 13 shows a graph of the proportion of long term unemployment (PLTU) in the G7. 
Figure 12: Unemployment Rates in the G7

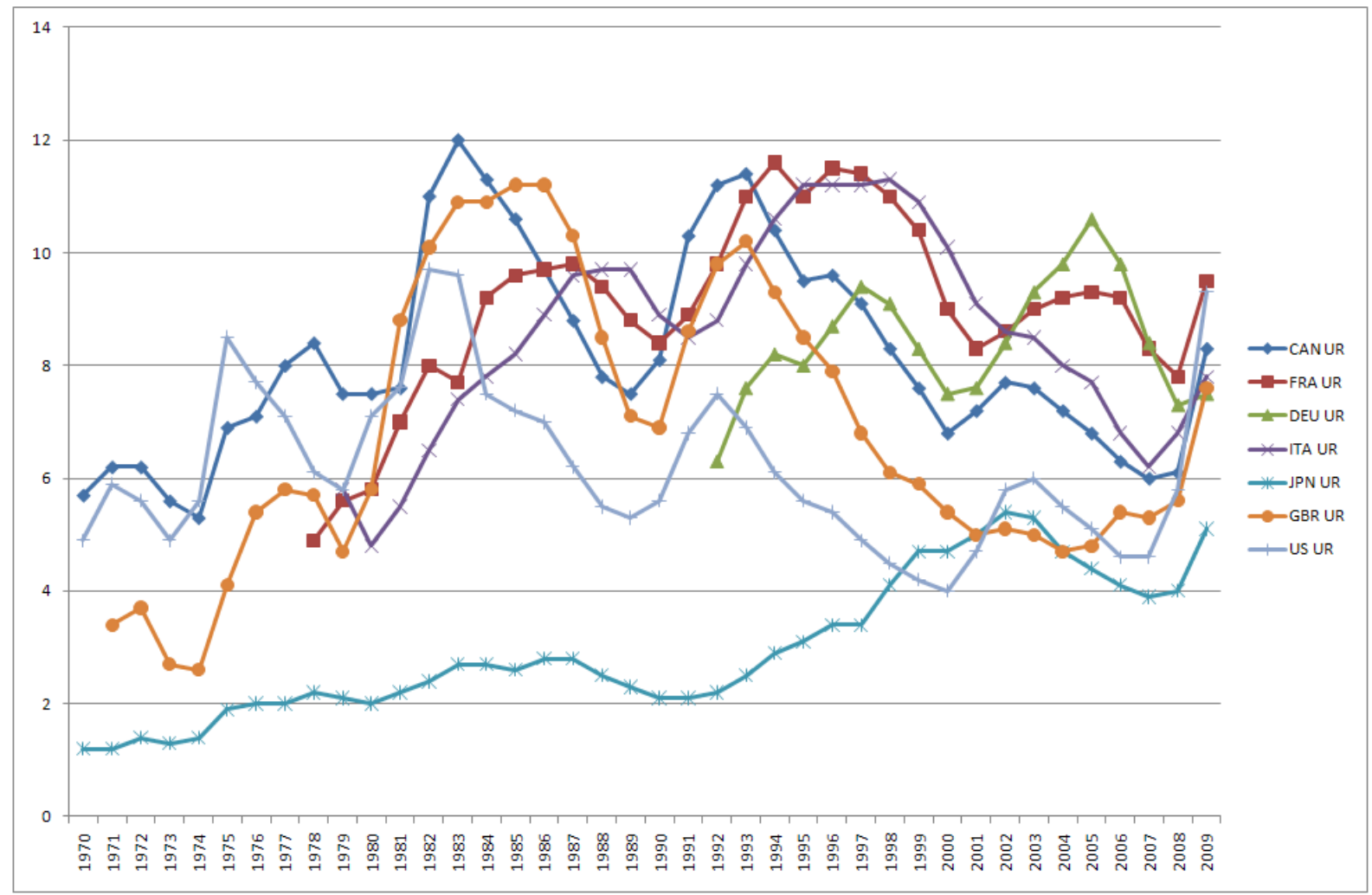

Source: OECD Annual Data

Figure 13: Proportion of Long Term Unemployment (PLTU) in the G7

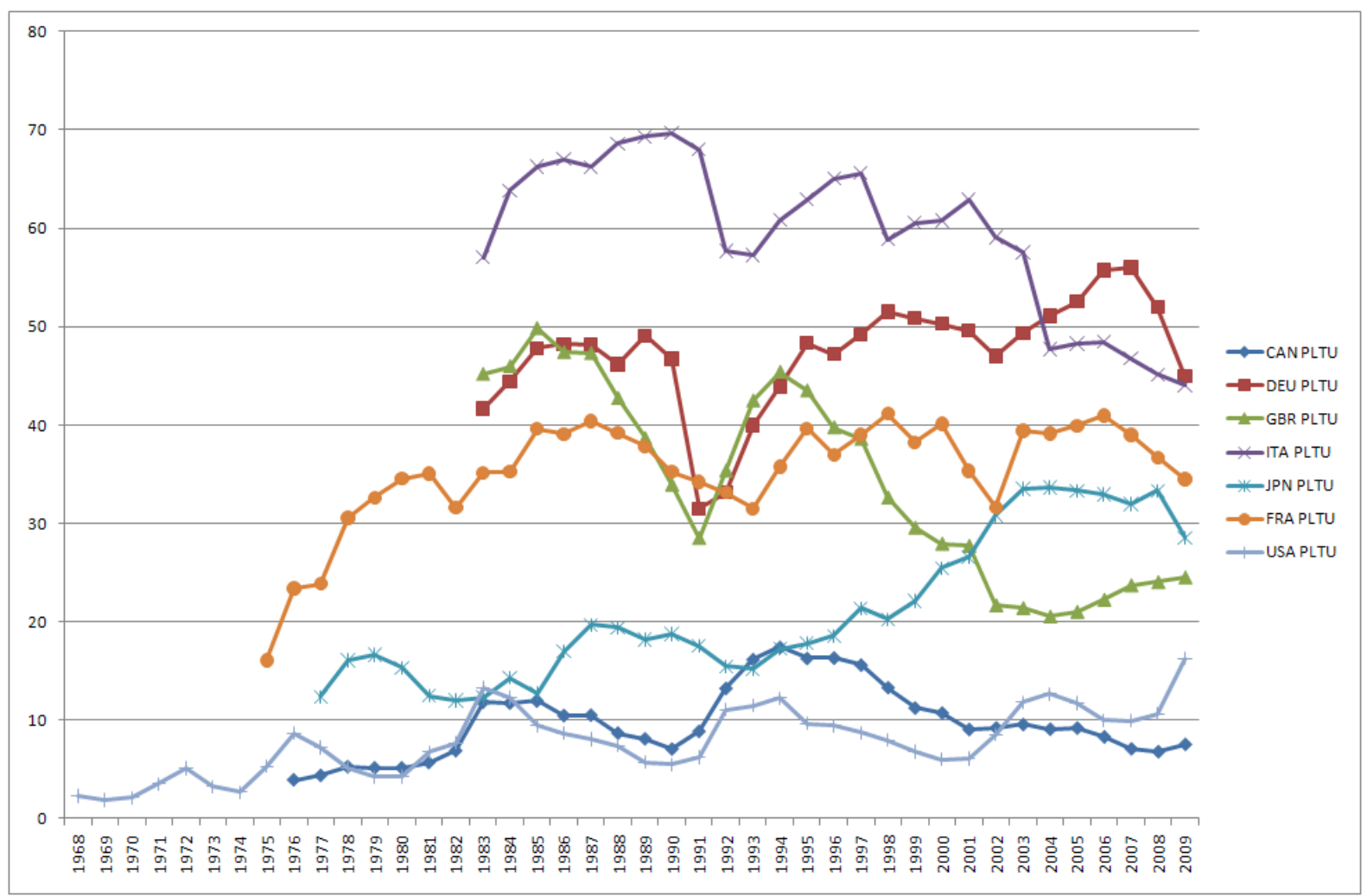

Source: OECD Annual PLTU Data 
Since most countries do not have duration data, except for the recent past, the comparison is mainly with the recession of the early nineteen-nineties.

Table 4: Unemployment Increases in Two Recessions

\begin{tabular}{|c|c|c|c|c|c|c|c|c|}
\hline & $\begin{array}{c}1990 \\
\text { Q2 }\end{array}$ & $\begin{array}{c}1993 \\
\text { Q4 }\end{array}$ & $\begin{array}{l}\text { Percentage } \\
\text { Point } \\
\text { increase in } \\
\text { UR in } \\
\text { 1990s }\end{array}$ & $\begin{array}{c}\text { Percentage } \\
\text { Increase in } \\
\text { URs, } \\
\text { 1990s }\end{array}$ & $\begin{array}{c}2007 \\
\text { Q4 }\end{array}$ & $\begin{array}{c}2010 \\
\text { Q3 }\end{array}$ & $\begin{array}{l}\text { Percentage } \\
\text { Point } \\
\text { increase in } \\
\text { UR in } \\
2007+\end{array}$ & $\begin{array}{l}\text { Percentage } \\
\text { Increase in } \\
\text { URs in } \\
2007+\end{array}$ \\
\hline AUS UR & 6.2 & 10.5 & 4.3 & 69.4 & 4.4 & 5.2 & 0.8 & 18.2 \\
\hline CAN UR & 7.6 & 11.3 & 3.7 & 48.7 & 5.9 & 8 & 2.1 & 35.6 \\
\hline FRA UR & 8.4 & 11.6 & 3.2 & 38.1 & 7.9 & 10 & 2.1 & 26.6 \\
\hline DEU UR & & 8.1 & & & 8 & 6.8 & -1.2 & -15.0 \\
\hline IRL UR & 13.2 & 15.4 & 2.2 & 16.7 & 4.8 & 13.9 & 9.1 & 189.6 \\
\hline ITA UR & 8.9 & 10.4 & 1.5 & 16.9 & 6.3 & 8.2 & 1.9 & 30.2 \\
\hline JPN UR & 2.1 & 2.7 & 0.6 & 28.6 & 3.9 & 5.1 & 1.2 & 30.8 \\
\hline NZL UR & 7.7 & 9.4 & 1.7 & 22.1 & 3.5 & 6.4 & 2.9 & 82.9 \\
\hline ESP UR & 13.1 & 19.3 & 6.2 & 47.3 & 8.6 & 20.6 & 12 & 139.5 \\
\hline SWE UR & 1.5 & 9.8 & 8.3 & 553.3 & 6 & 8.3 & 2.3 & 38.3 \\
\hline GBR UR & 6.7 & 10.1 & 3.4 & 50.7 & 5.1 & 7.8 & 2.7 & 52.9 \\
\hline USA UR & 5.3 & 6.6 & 1.3 & 24.5 & 4.8 & 9.6 & 4.8 & 100.0 \\
\hline $\begin{array}{c}\text { OECD } \\
\text { UR }\end{array}$ & 6 & 7.9 & 1.9 & 31.7 & 5.7 & 8.5 & 2.8 & 49.1 \\
\hline G7 UR & 5.4 & 7.2 & 1.8 & 33.3 & 5.4 & 8.1 & 2.7 & 50.0 \\
\hline
\end{tabular}

Source: OECD Harmonised Quarterly URs

Table 4 presents the increases in unemployment rates in the recessions of the early nineteennineties and the Great Recession. What is obvious from this Table is that the Great Recession hit Spain, Ireland and the USA very hard, while in the 1990s recession Sweden, Spain, and Australia were most hard hit. As discussed earlier we would expect that these differences would also be similar when considering the size of the increases in long term unemployment in these countries. Unfortunately, unemployment duration data on a quarterly basis are not available for most of the OECD countries for a sufficiently long time series to compare these two recessions. Initially, we will use annual data for a considerable number of the OECD countries, and then look in more detail at the USA for which we have duration data on a quarterly basis. 
Figure 12: Unemployment Rates in Two Recessions

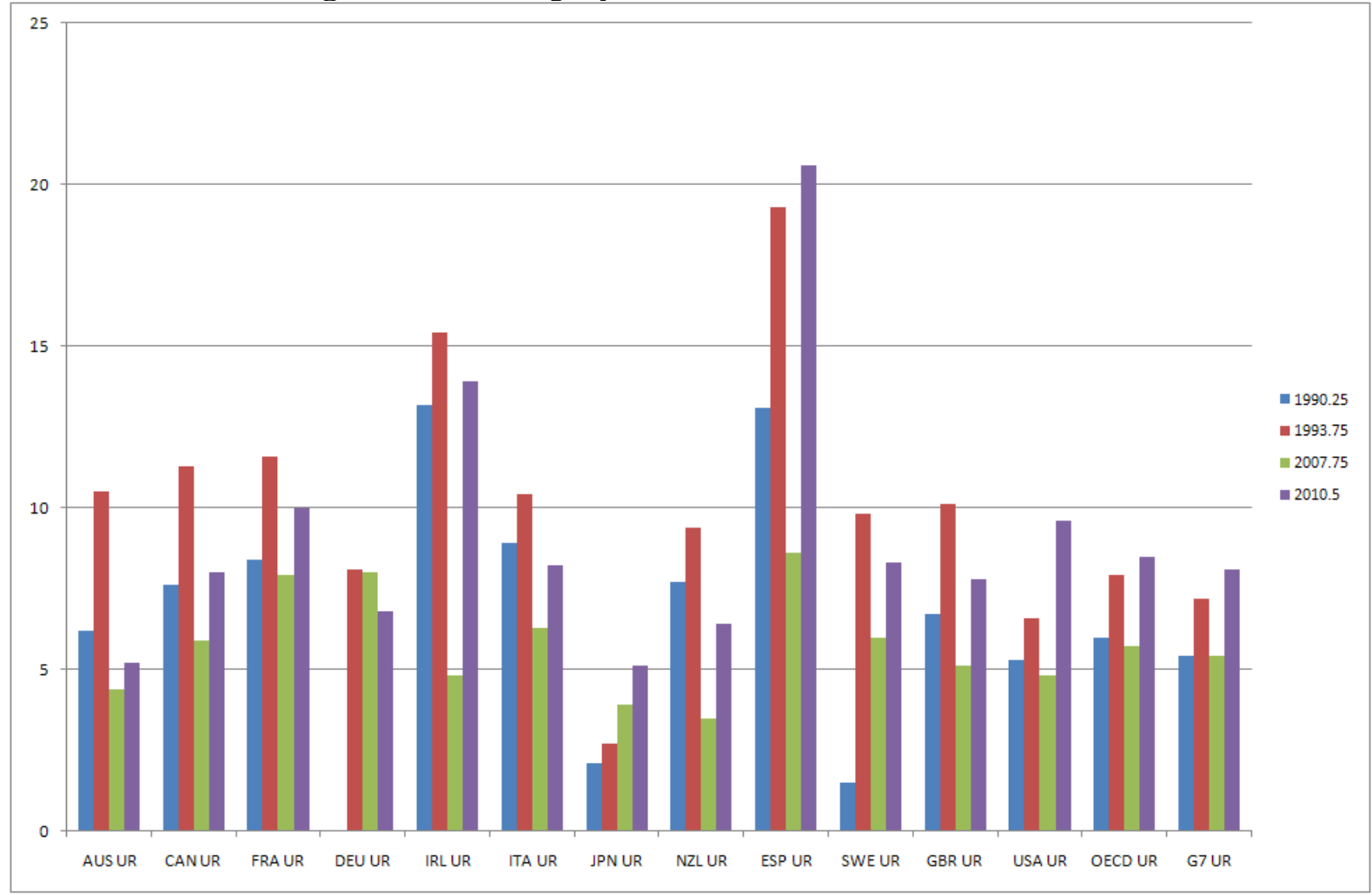

Source: OECD Harmonised Quarterly URs 
Table 5: Percentage Increase in Long Term Unemployment, 1990-93 \& 2007-2009

\begin{tabular}{|l|c|c|c|c|}
\hline & $\begin{array}{c}\text { \% Increase in } \\
\text { LTU, 1990-93 }\end{array}$ & $\begin{array}{c}\text { \% Increase in } \\
\text { LTU 2007-2009 }\end{array}$ & $\begin{array}{c}\text { \% Increase in } \\
\text { PLTU, 1990-93 }\end{array}$ & $\begin{array}{c}\text { \% Increase in } \\
\text { PLTU 2007-2009 }\end{array}$ \\
\hline AUS & 179.6 & 26.6 & 74.1 & -4.4 \\
\hline AUT & & -12.4 & & -24.5 \\
\hline BEL & -8.3 & -5.5 & -21.1 & -12.1 \\
\hline CAN & 225.6 & 49.9 & 129.6 & 6.5 \\
\hline DEU & 72.3 & -28.0 & -14.4 & -19.7 \\
\hline DNK & 8.6 & -10.1 & -14.9 & -43.7 \\
\hline ESP & 34.2 & 171.7 & -6.4 & 20.1 \\
\hline FIN & & -12.3 & & -27.0 \\
\hline FRA & 9.4 & 2.9 & -10.6 & -11.6 \\
\hline G7 & 36.7 & 28.9 & 4.5 & -13.5 \\
\hline GBR & 80.6 & 50.6 & 25.2 & 3.4 \\
\hline GRC & 39.9 & -5.4 & 1.8 & -18.3 \\
\hline IRL & 1.4 & 145.5 & -11.6 & -2.7 \\
\hline ITA & -16.6 & 21.7 & -17.8 & -5.8 \\
\hline JPN & -11.1 & 17.7 & -19.0 & -10.8 \\
\hline NLD & -20.2 & -30.6 & -6.8 & -36.5 \\
\hline NOR & 55.0 & 18.4 & 33.2 & -10.6 \\
\hline NZL & 167.5 & 92.9 & 107.7 & 12.1 \\
\hline OECD & 49.8 & 23.3 & 2.5 & -16.0 \\
\hline PRT & -12.9 & 10.1 & -21.4 & -6.6 \\
\hline SWE & 560.1 & 38.3 & 31.2 & -16.7 \\
\hline TUR & 11.7 & 21.6 & -1.0 & 63.3 \\
\hline USA & 165.6 & 229.3 & 109.4 & \\
\hline
\end{tabular}

\section{Source: OECD Annual Data}

Table 5 shows that the early nineteen-nineties recession was much more severe for Australia, Canada, New Zealand, and the USA compared to some of the other countries. However, since these data are annual they do not reflect the growth of long term unemployment in the Great Recession, as the data end in 2009 while the effects of the recession are still being felt. As we saw in the earlier section, long term unemployment continued to increase in most countries into 2010.

Table 6 combines data from the annual series for the 1990s recession with the quarterly series of the Great Recession to give a better picture since the quarterly data are more recent and in general, long term unemployment tends to continue to increase for a much longer time than the unemployment rate. 
Table 6: Increase in Long Term Unemployment, 1990-93 \& 2007 Q4-2009 Q3

\begin{tabular}{|l|c|l|l|l|l|c|}
\hline & $\begin{array}{l}\text { Percentage } \\
\text { Increase in } \\
\text { NLTU, } \\
\text { 1990-93 }\end{array}$ & $\begin{array}{l}\text { Point } \\
\text { Increase in } \\
\text { PLTU, } \\
\mathbf{1 9 9 0 - 1 9 9 3}\end{array}$ & $\begin{array}{l}\text { Percentage } \\
\text { Increase in } \\
\text { PLTU, } \\
\mathbf{1 9 9 0 - 9 3}\end{array}$ & $\begin{array}{l}\text { Percentage } \\
\text { Increase in } \\
\text { NLTU, } \\
\text { 2007 Q4- } \\
\text { 2010 Q3 }\end{array}$ & $\begin{array}{l}\text { Percentage } \\
\text { Point } \\
\text { Increase in } \\
\text { PLTU, } \\
\text { 2007 Q4- } \\
\text { 2010 Q3 }\end{array}$ & $\begin{array}{l}\text { Percentage } \\
\text { Increase in } \\
\text { PLTU, } \\
\text { 2007 Q4- } \\
\text { 2010 Q3 }\end{array}$ \\
\hline AUS & 179.62 & 15.63 & 74.12 & 67.40 & 4.55 & 31.59 \\
\hline AUT & & & & 7.42 & -1.31 & -5.16 \\
\hline BEL & -8.26 & -14.13 & -21.07 & 18.62 & -3.03 & -5.83 \\
\hline CAN & 225.58 & 9.14 & 129.63 & 139.59 & 3.98 & 53.11 \\
\hline DEU & 72.26 & -6.74 & -14.42 & -32.02 & -9.59 & -16.93 \\
\hline DNK & 8.59 & -4.38 & -14.91 & 227.17 & 5.84 & 39.95 \\
\hline ESP & 34.16 & -3.41 & -6.41 & 357.95 & 18.03 & 92.96 \\
\hline FIN & & & & 51.10 & 5.44 & 24.51 \\
\hline FRA & 9.39 & -3.72 & -10.55 & 32.73 & 3.39 & 9.02 \\
\hline GBR & 80.61 & 8.55 & 25.20 & 114.96 & 8.01 & 32.65 \\
\hline GRC & 39.87 & 0.88 & 1.78 & 46.46 & -3.28 & -6.63 \\
\hline IRL & 1.39 & -7.60 & -11.61 & 408.95 & 21.50 & 76.58 \\
\hline ITA & -16.55 & -12.43 & -17.83 & 24.15 & 4.65 & 10.23 \\
\hline JPN & -11.11 & -3.56 & -18.99 & -100.00 & -34.54 & -100.00 \\
\hline NLD & -20.18 & -3.31 & -6.79 & 9.06 & -10.95 & -28.44 \\
\hline NOR & 55.00 & 6.78 & 33.25 & 105.17 & 4.16 & 24.82 \\
\hline NZL & 167.53 & 16.09 & 107.72 & 221.88 & 2.91 & 68.85 \\
\hline PRT & -12.88 & -9.56 & -21.38 & 57.89 & 6.53 & 13.88 \\
\hline SWE & 560.09 & 3.77 & 31.22 & 87.37 & 3.92 & 26.99 \\
\hline TUR & 11.73 & -0.45 & -0.98 & 35.12 & 1.71 & 6.94 \\
\hline USA & 165.63 & 6.01 & 109.41 & 532.82 & 20.92 & 234.79 \\
\hline & & & & & & \\
\hline
\end{tabular}

Source: OECD Annual and Quarterly data 
Table 7: Worst hit countries in the two Recessions

\begin{tabular}{|c|c|c|c|c|c|}
\hline $\begin{array}{l}\text { Percentage } \\
\text { Increase in } \\
\text { NLTU, } \\
1990-93\end{array}$ & $\begin{array}{l}\text { Percentage } \\
\text { Point } \\
\text { Increase in } \\
\text { PLTU, } \\
\text { 1990-1993 }\end{array}$ & $\begin{array}{l}\text { Percentage } \\
\text { Increase in } \\
\text { PLTU, } \\
\text { 1990-93 }\end{array}$ & $\begin{array}{l}\text { Percentage } \\
\text { Increase in } \\
\text { NLTU, } \\
2007 \text { Q4- } \\
2010 \text { Q3 }\end{array}$ & $\begin{array}{l}\text { Percentage } \\
\text { Point } \\
\text { Increase in } \\
\text { PLTU, } \\
2007 \text { Q4- } \\
2010 \text { Q3 }\end{array}$ & $\begin{array}{l}\text { Percentage } \\
\text { Increase in } \\
\text { PLTU, } \\
2007 \text { Q4- } \\
2010 \text { Q3 }\end{array}$ \\
\hline SWE & NZL & CAN & USA & IRL & USA \\
\hline CAN & AUS & USA & IRL & USA & ESP \\
\hline AUS & CAN & NZL & ESP & ESP & IRL \\
\hline NZL & GBR & AUS & DNK & GBR & NZL \\
\hline USA & NOR & NOR & NZL & PRT & CAN \\
\hline
\end{tabular}

Source: Table 6

Tables 6 and 7 provide a better picture of the impact of the two recessions on long term unemployment. The USA clearly did worse in the Great Recession, compared to the 1990s recession in terms of the growth of the numbers in long term unemployment, as well as in terms of the percentage of long term unemployment (PLTU). Ireland and Spain also did very badly in the Great Recession compared to the 1990s recession. If we use the percentage increase in NLTU the USA had the biggest increase in the Great Recession, followed by Ireland, Spain, Denmark and New Zealand. In the 1990s recession, Sweden did the worst, followed by Canada, Australia, New Zealand and the USA. In terms of the Percentage point increase in PLTU, in the Great Recession Ireland did the worst followed by the USA, Spain, Great Britain, and Portugal. In the 1990s recession in terms of the Percentage Point increase in PLTU, the worst case was New Zealand followed by Australia, Canada, Great Britain, and Norway. In terms of the Percentage increase in PLTU in the Great Recession, the USA was the worst affected followed by Spain, Ireland, New Zealand, and Canada. In the 1990s recession in terms of the Percentage increase in PLTU, Canada fared the worst, followed by the USA, New Zealand, Australia, and Norway. Clearly the rankings depend on which measure we use. There is no obvious "correct" measure. In the literature we usually use PLTU, and the percentage increase in PLTU. However, in all these alternative metrics we find that in the Great Recession the USA, Ireland and Spain did very badly. 
In the next section we look at the USA in more detail as unemployment duration data on a quarterly basis are available for a longer period.

\section{A Detailed Analysis of USA}

In this section, we make use of quarterly data for the USA from 1970 Q1 for the unemployment rate, and 1976 Q1 for data on the numbers of long term unemployed (NLTU) and the proportion of long term unemployment (PLTU), to compare long term unemployment in the last four recessions (Figures 13 and 14). The unemployment rate went up significantly in the recession of the early 1970s (peaked in the second quarter of 1975) and we see that NLTU and PLTU begin to fall from 1976 Q1 (when the data series begin). The 1980s recession saw a big increase in unemployment rates (rising from 1980 Q1 and peaking in 1982 Q4). As a result NLTU also rises and peaks in 1983 Q2 while PLTU rises and peaks in 1984 Q1. The subsequent recessions of the 1990s and the early 2000 were milder in terms of the peaks of unemployment rates and of NLTU and PLTU. The troughs of the unemployment rate, NLTU and PLTU after the recession of the early 2000 were higher than the previous recession. The Great Recession shows that the unemployment rates and the NLTU and PLTU jump up at a very rapid rate (unseen before this period).

Figure 13: A Time Series of NLTU, PLTU and UR for the USA

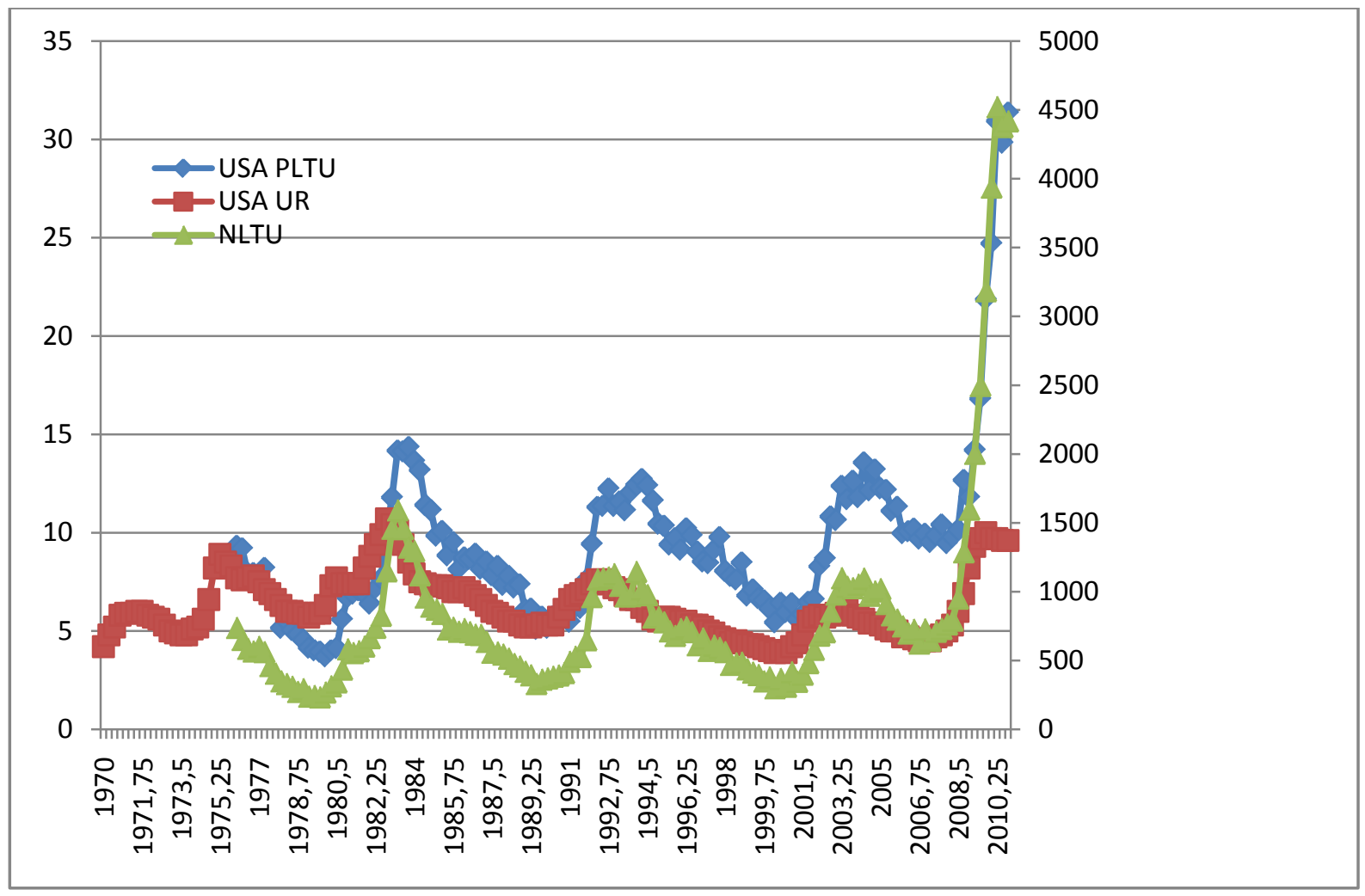

Source: USA_UDUR.xlsx \& OECD Harmonised URs. NLTU measured on right hand scale. 
Figure 14: NLTU and PLTU in the Great Recession

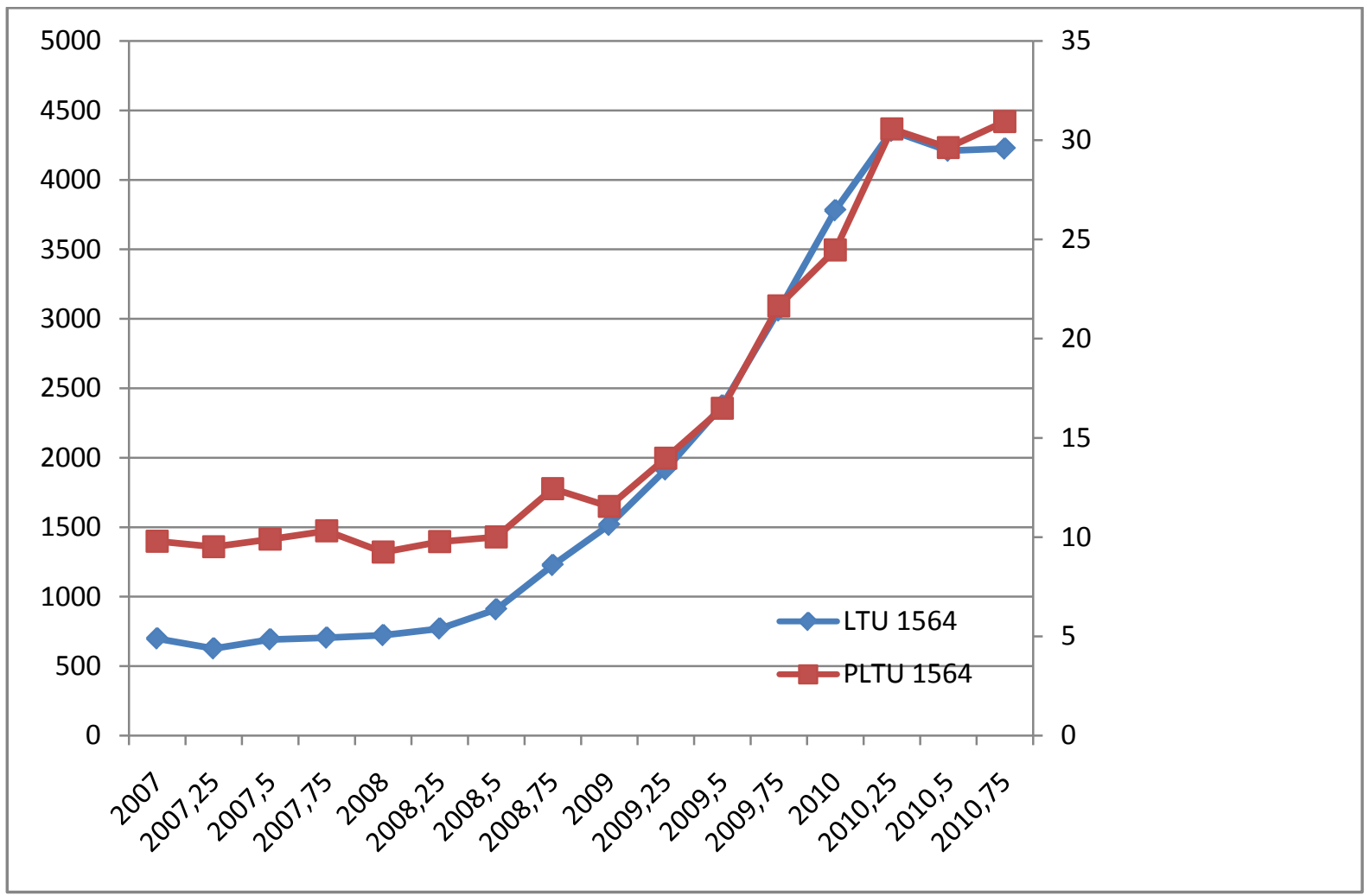

Figure 15: Time Paths of the Proportion of Long Term Unemployment in Four Recessions, USA

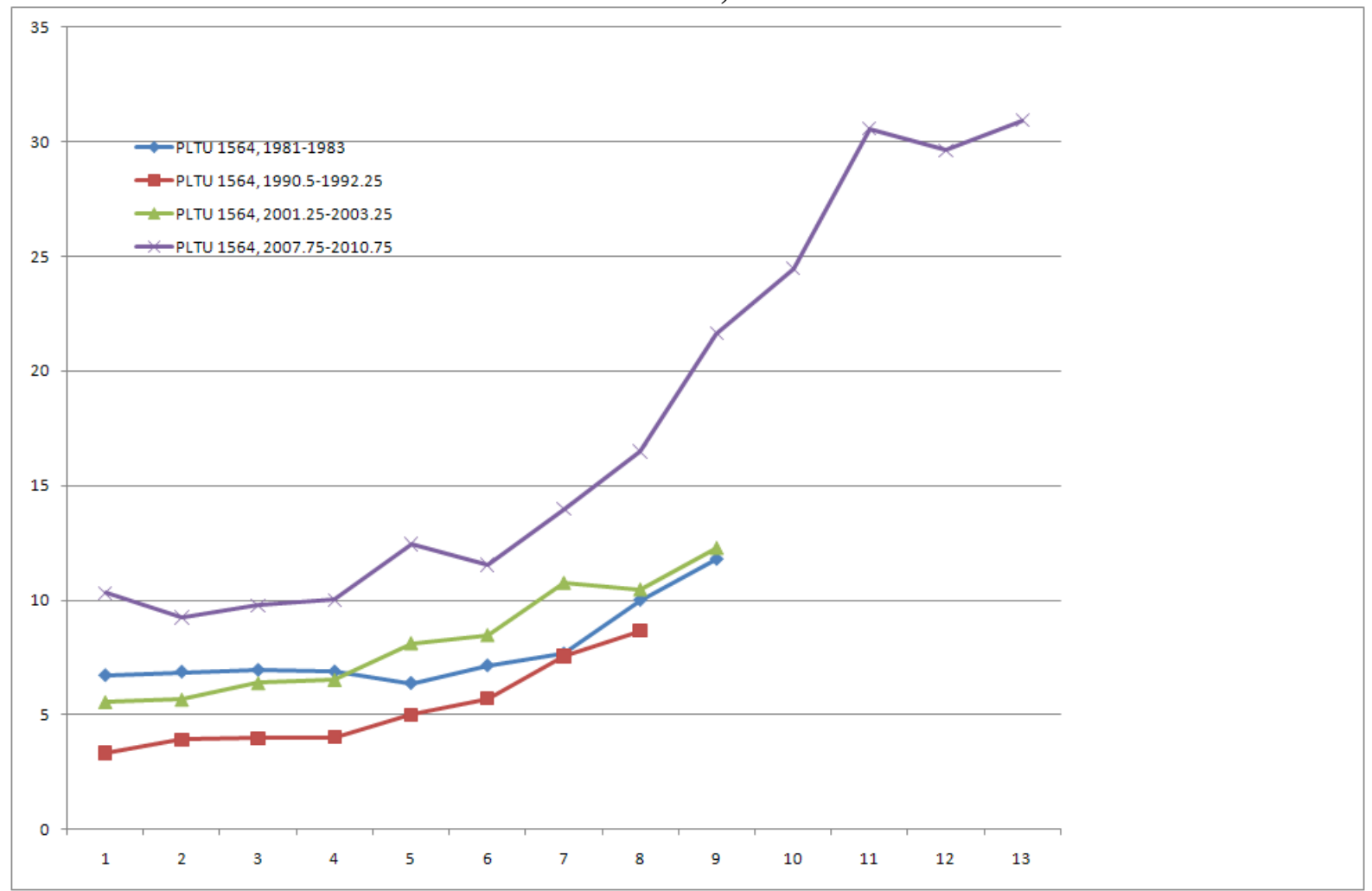

Source: USA_UDUR.xlsx 
Figure 15 shows that the Great Recession was clearly the most severe in recent history with PLTU rising more rapidly than in any of the previous recessions. If you exclude the recession of the 1980s, each successive recession has PLTU beginning at a higher level than the previous recession.

Table 8 plots a time line for the minima and maxima of the percentage of long term unemployment, and the duration between each minimum and maximum. It shows that in the 1980s recession it took 15 Quarters for it to reach a maximum, and 25 Quarters for it to reach the next minimum; in the 1990s recession it took 17 Quarters to reach a maximum and 28 Quarters to the next minimum; in the 2001 recession it took 12 Quarters to reach a maximum and only 15 Quarters to reach a minimum. Note, however, that each minimum is higher than the preceding one, and that it takes a long time to reach a maximum.

Table 8: Peaks and Troughs in Long Term Unemployment

\begin{tabular}{|r|r|l|}
\hline & PLTU & \\
\hline 1980 & 3.643 & $\min$ \\
\hline Duration & & $15 Q$ \\
\hline 1983.75 & 14.3208 & $\max$ \\
\hline Duration & & $25 Q$ \\
\hline 1990 & 5.04507 & $\min$ \\
\hline Duration & & $17 Q$ \\
\hline 1994.25 & 12.5064 & $\max$ \\
\hline Duration & & $28 Q$ \\
\hline 2001.25 & 5.56048 & $\min$ \\
\hline Duration & & $12 Q$ \\
\hline 2004.25 & 13.3833 & $\max$ \\
\hline Duration & & $15 Q$ \\
\hline 2008 & 9.24203 & $\min$ \\
\hline Source
\end{tabular}

Source: USA_DUR.xls 
Figure 16: Four Cycles of Long Term Unemployment (PLTU), USA

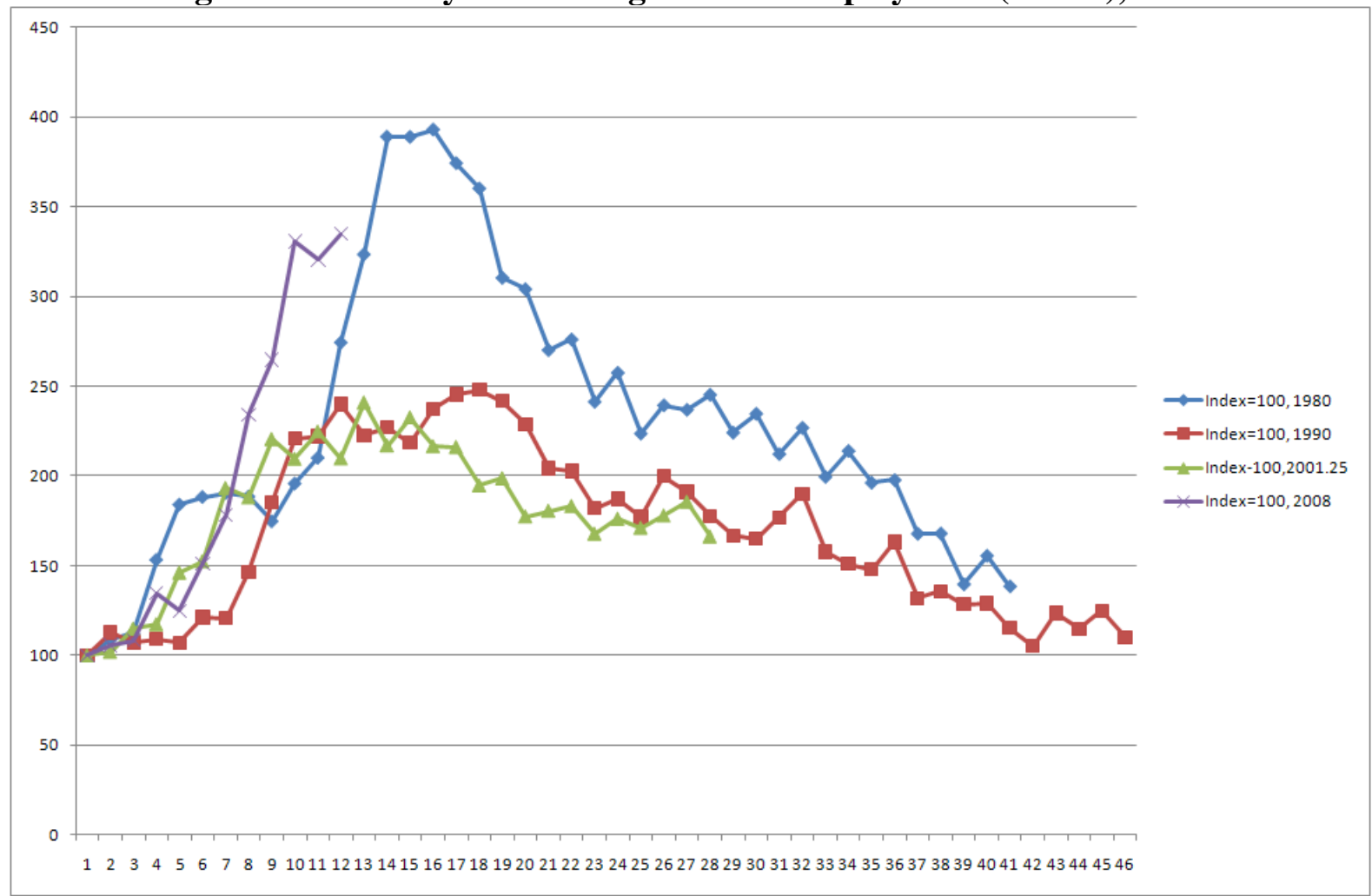

Source: USA_UDUR.xls, author's calculations.

In order to compare the changes in PLTU we have indexed the beginning of each recession as 100 in Figure $16^{8}$. This Figure 15 shows clearly that the early stages of the Great Recession produced the steepest percentage increase in the proportion of long term unemployment (PLTU). This diagram also clearly shows that long term unemployment (as measured by PLTU) increases very rapidly but comes down very slowly. Since the present cycle is not yet over, it is unclear whether the total rise in PLTU will end up being a larger or smaller than the total rise following the 1980s recession, but it will probably be of a similar magnitude. Another feature that stands out from this figure is that PLTU increases more rapidly than it falls: there appears to be an asymmetrical response to increases and decreases in unemployment rates. We will consider this in our econometric analysis later in this paper. In each of the four recessions considered, once long term unemployment (PLTU) has increased, it never returns to the previous minimum, although it nearly did in the 1990s.

If we turn to how recessions hit males and females, we see that males have a much larger increase in long term unemployment. As Table 9 and Figures 17a and b show the increases in

\footnotetext{
8 This diagram is clearly affected by the start date chosen for recessions as we have indexed it to 100 . There is a question whether the recession of 1980 is really just a continuation of an earlier 1979 recession, in which case the diagram may look different.
} 
male and female long term unemployment in the Great Recession was spectacular compared to earlier recessions. Of course, as the participation rate of females has increased over the past few decades, the number of long term unemployed (NLTU) may exaggerate the increases in long term unemployment, and hence the proportion of long term unemployment (PLTU) which normalises the numbers of long term unemployed by the total unemployed is a better metric.

Table 9: Male and Female Long Term Unemployment in Four Recessions

\begin{tabular}{|r|c|c|c|c|}
\hline & $\begin{array}{l}\text { Male Long Term } \\
\text { Unemployment } \\
\text { (MNLTU), 1564 } \\
\text { (000s) }\end{array}$ & $\begin{array}{l}\text { Female Long } \\
\text { Term } \\
\text { Unemployment } \\
\text { (FNLTU), 1564 } \\
\text { (000s) }\end{array}$ & $\begin{array}{l}\text { Male Proportion } \\
\text { of LTU (PLTU), } \\
\mathbf{1 5 6 4}\end{array}$ & $\begin{array}{l}\text { Female Proportion } \\
\text { of LTU (PLTU), } \\
\mathbf{1 5 6 4}\end{array}$ \\
\hline $\mathbf{1 9 8 1}$ & 389.2 & 187.6 & 7.7 & 5.3 \\
\hline $\mathbf{1 9 8 3}$ & 1025.9 & 418.9 & 13.7 & 8.7 \\
\hline $\begin{array}{r}\text { Percentage } \\
\text { Increase }\end{array}$ & $\mathbf{1 6 3 . 6}$ & $\mathbf{1 2 3 . 4}$ & $\mathbf{7 7 . 7}$ & $\mathbf{6 6 . 2}$ \\
\hline $\mathbf{1 9 9 0 . 5}$ & 265.9 & 111.8 & 7.3 & 3.3 \\
\hline $\mathbf{1 9 9 2 . 2 5}$ & 712.2 & 345.4 & 12.9 & 8.7 \\
\hline $\begin{array}{r}\text { Percentage } \\
\text { Increase }\end{array}$ & $\mathbf{1 6 7 . 8}$ & $\mathbf{2 0 9 . 0}$ & $\mathbf{7 6 . 1}$ & $\mathbf{1 5 9 . 4}$ \\
\hline $\mathbf{2 0 0 1 . 2 5}$ & 189.4 & 149.5 & 5.7 & 10.6 \\
\hline $\mathbf{2 0 0 3 . 2 5}$ & 660.1 & 407.8 & 13.6 & $\mathbf{9 8 . 0}$ \\
\hline $\begin{array}{r}\text { Percentage } \\
\text { Increase }\end{array}$ & $\mathbf{2 4 8 . 5}$ & $\mathbf{1 7 2 . 7}$ & $\mathbf{1 3 6 . 5}$ & 10.3 \\
\hline $\mathbf{2 0 0 7 . 7 5}$ & 386.4 & 317.9 & 10.4 & 29.3 \\
\hline $\mathbf{2 0 1 0 . 7 5}$ & 2466.9 & 1757.8 & 32.2 & $\mathbf{1 8 5 . 5}$ \\
\hline $\begin{array}{l}\text { Percentage } \\
\text { Increase }\end{array}$ & $\mathbf{5 3 8 . 5}$ & $\mathbf{4 5 2 . 9}$ & $\mathbf{2 1 1 . 1}$ & \\
\hline
\end{tabular}

Source: USA_UDUR.xlsx 
Figure 17a: Numbers of Long Term Unemployed (NLTU) in the USA, Four Recessions

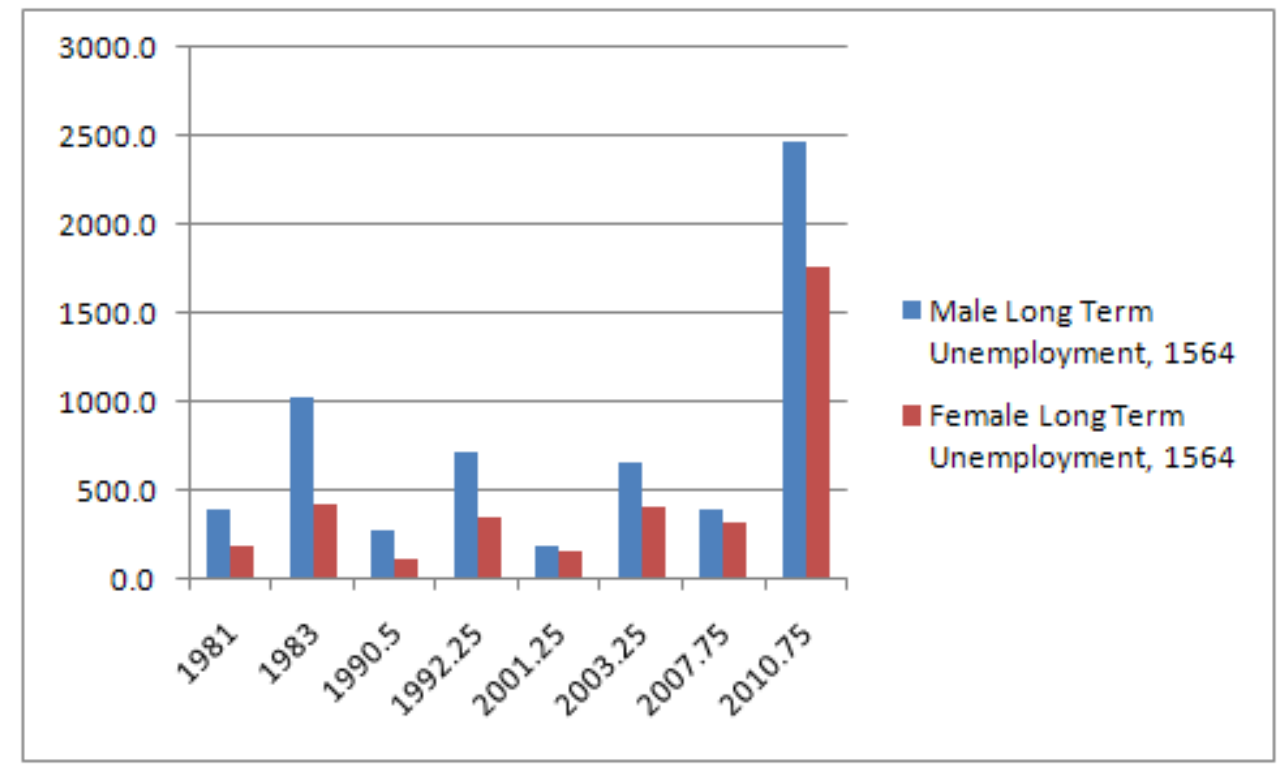

Figure 17b: Proportion of Long Term Unemployment in the USA, Four Recessions

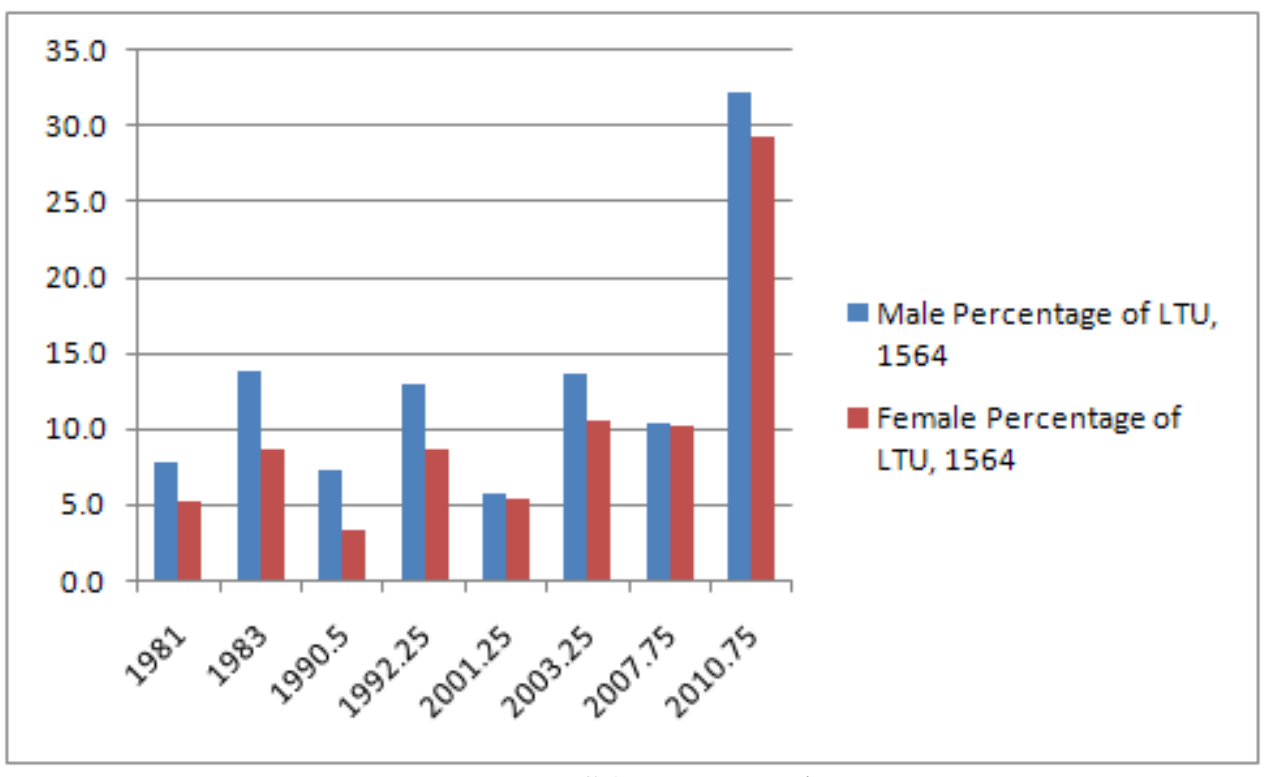

Source: USA_UDUR.xlsx

If we turn to the distribution of unemployment and long term unemployment by industry breakdown (agriculture, industry, and services) we see (Figure 18) that the share of industry Long Term Unemployment increased more in the 2001 recession than in the Great Recession. However, the percentage point increases in the Proportion of Long Term Unemployment (PLTU) were greater in the Great Recession compared to the 2001 recession. 
Figure 18: Percentage of Long Term Unemployment in the USA, Four Recessions

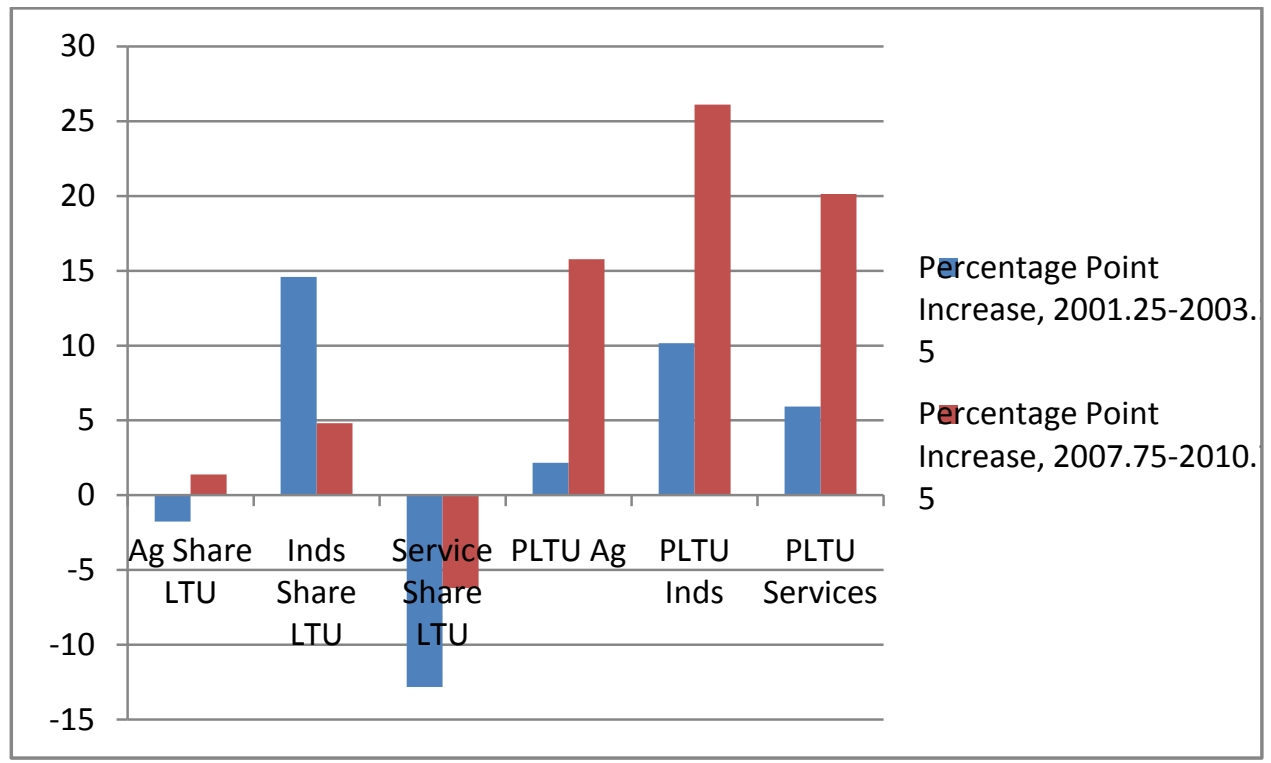

Source: USA_UDUR_REQ2

If we now turn to the breakdown of long term unemployment by skills (Figure 19), we see that there was a greater increase in the Proportion of Long Term Unemployment (PLTU) for each skill level in the Great Recession compared to the recession of 2001.

Figure 19: Percentage Point Increase in the Proportion of Long Term Unemployment by Skill

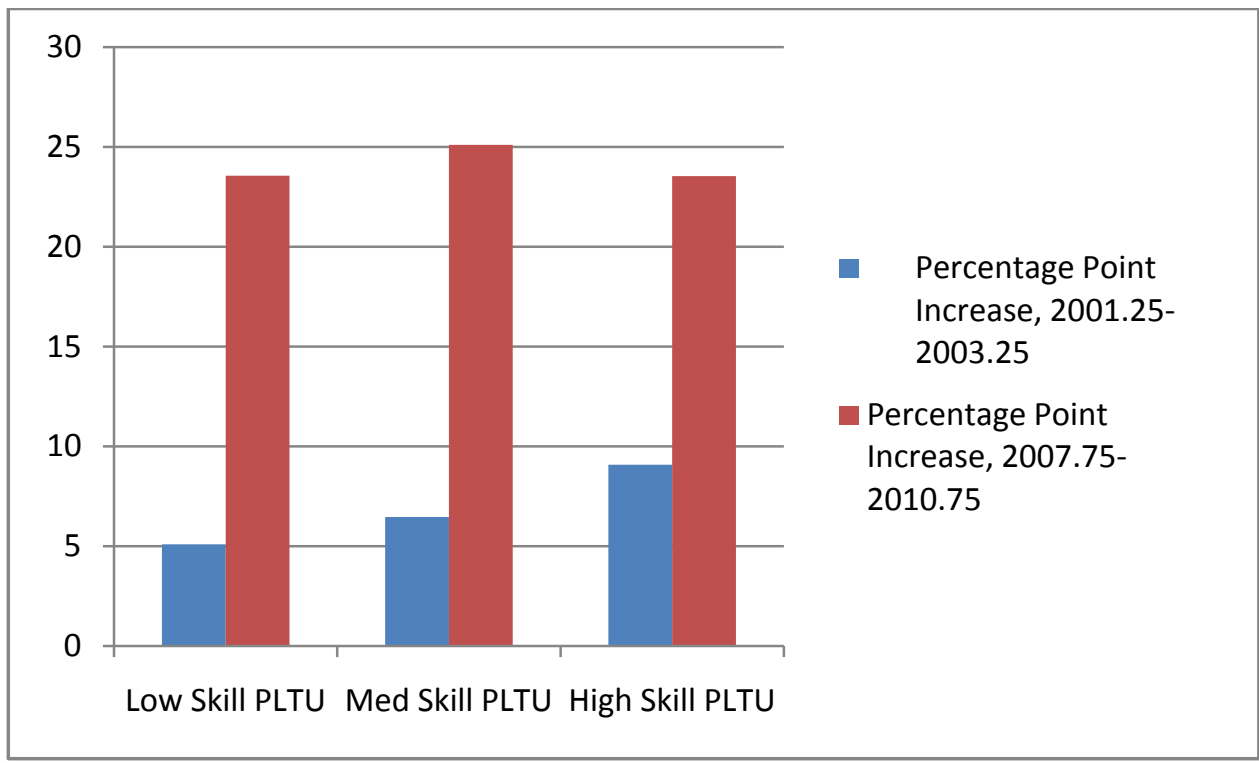

Source: USA-Unemployment duration by education and migration status.xlsx (18-03-2011, Sebastien Martin). 
If we look at the shares of long term unemployment in total long term unemployment by skill (Figure 20), we see that there was a bigger increase in the high skill share of LTU and a greater fall in that of low skilled workers in the 2001 recession compared to the Great Recession.

Figure 20: Shares of Long Term Unemployment by Skill

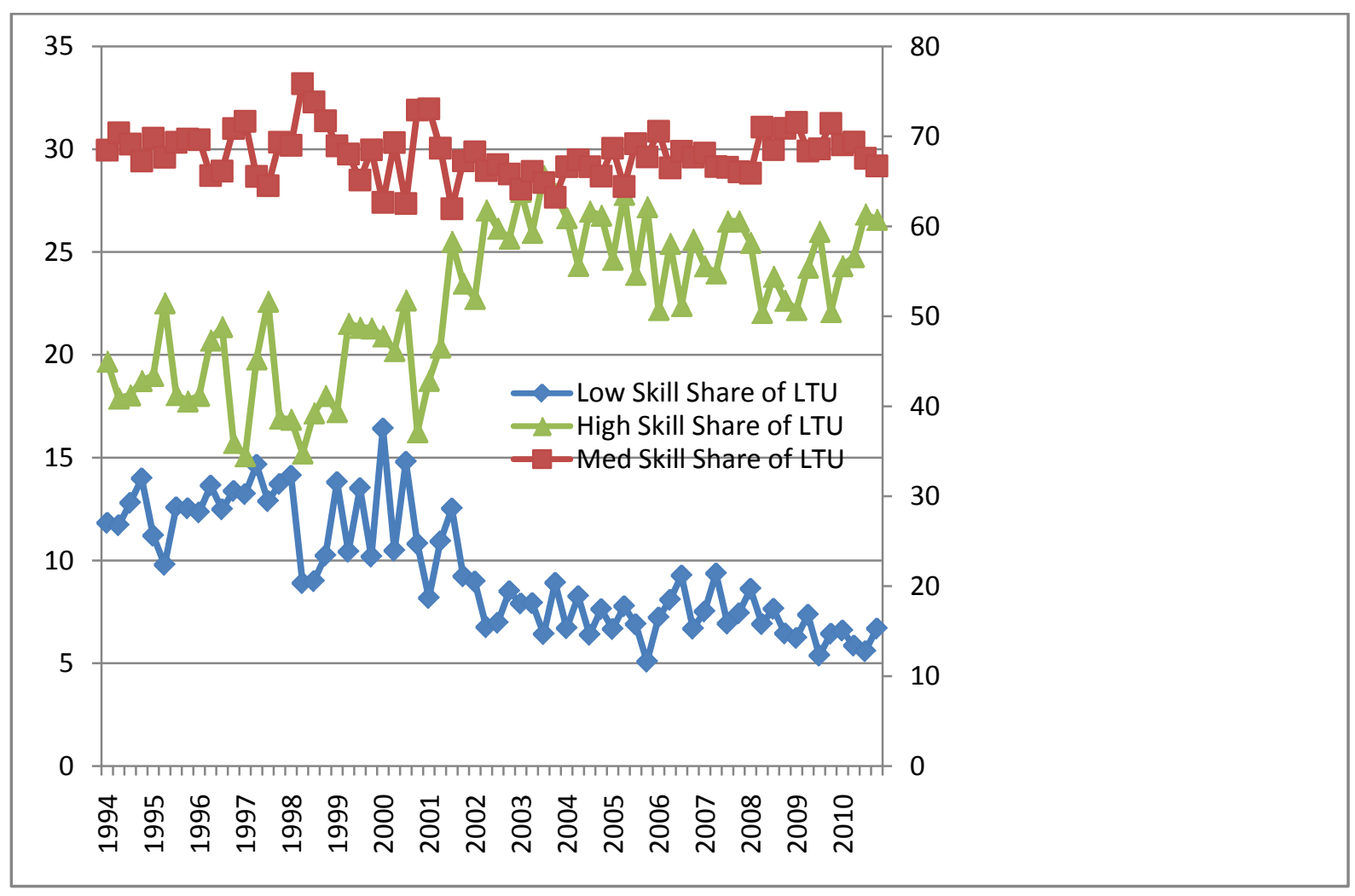

Source: USA-Unemployment duration by education and migration status.xlsx (18-03-2011, Sebastien Martin).

If we now turn to look at the shares of migrants who are in long term unemployment from low and high skill jobs (Figure 21), we see that there was a slight upward trend in the ratio of migrant to natives from low skill jobs after about 2004 Q3 and a huge upward spike with the beginning of the Great Recession. There was also a slight downward trend in the ratio of migrants to natives in long term unemployment from high skill jobs. There appears to be much greater volatility in the ratio of long term unemployed migrants to natives in high skill jobs. 
Figure 21: Shares of Migrants by Skill in Long Term Unemployment

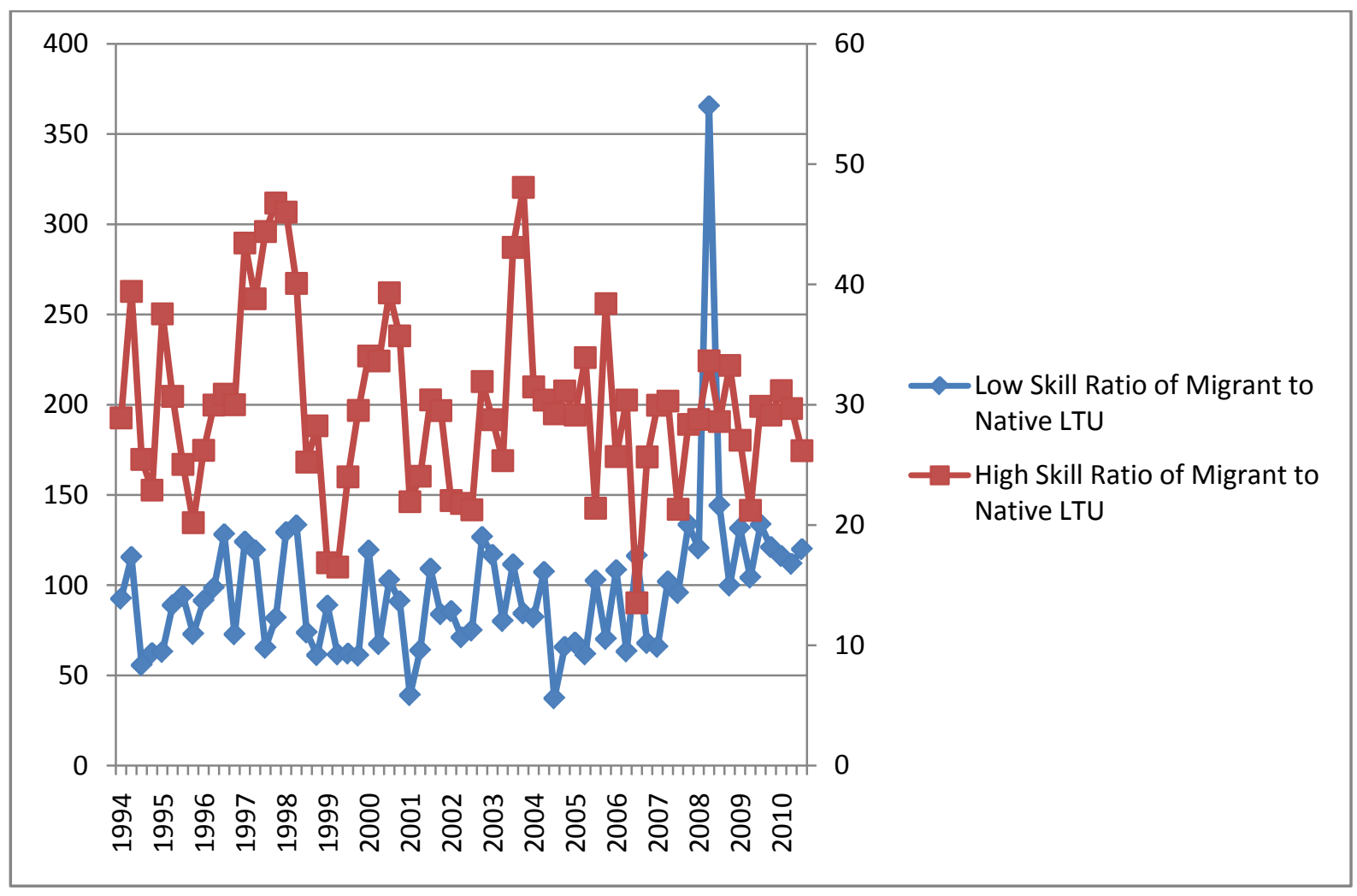

Source: USA-Unemployment duration by education and migration status.xlsx (18-03-2011, Sebastien Martin). 
Table 10a: Volatility of the Proportion of Long Term Unemployment, USA, 1976 Q1 to 2010 Q4

\begin{tabular}{|c|c|c|}
\hline & Std Dev & $\begin{array}{l}\text { Coefficient of } \\
\text { Variation }\end{array}$ \\
\hline Male PLTU 1564 & 4.61 & 0.43 \\
\hline Female PLTU 1564 & 4.41 & 0.56 \\
\hline PLTU 1564 & 4.46 & 0.47 \\
\hline Male PLTU 1524 & 3.34 & 0.53 \\
\hline Female PLTU 1524 & 2.85 & 0.61 \\
\hline PLTU 1524 & 3.08 & 0.55 \\
\hline Male PLTU 2554 & 5.06 & 0.40 \\
\hline Female PLTU 2554 & 4.82 & 0.52 \\
\hline PLTU 2554 & 4.84 & 0.44 \\
\hline Male PLTU 5564 & 6.15 & 0.34 \\
\hline Female PLTU 5564 & 6.10 & 0.47 \\
\hline PLTU 5564 & 5.76 & 0.36 \\
\hline
\end{tabular}

Source: USA_UDUR.xlsx

As an index of volatility of the proportion of long term unemployment (PLTU), Table 10a shows the coefficient of variation for different age and gender groups over the entire period, 1976 Q1 to 2010 Q4 ${ }^{9}$. In general, the volatility of PLTU is greater for females than for males. To see changes in volatility over time we have calculated the coefficients of variation for males and females (by age) for four recessions, see Table 10(b) below.

\footnotetext{
${ }^{9}$ We did try to provide similar results by removing a simple time trend, but since there was a huge jump of long term unemployment in the Great Recession, a simple time trend does not fit the data well. We did not try any other sophisticated detrending methods. However, we estimated similar coefficients of variation by age for four different recessions separately, see Table 10(b) below.
} 
Table 10(b): Volatility of the Proportion of Long Term Unemployment over Four Recessions

\begin{tabular}{|l|c|c|c|}
\hline & MPLTU, 15-24 & MPLTU, 25-54 & MPLTU, 55-64 \\
\hline $\begin{array}{l}\text { 1981Q1 - } \\
\text { 1983Q1 }\end{array}$ & $\mathbf{0 . 2 5}$ & $\mathbf{0 . 3 1}$ & $\mathbf{0 . 2 9}$ \\
\hline $\begin{array}{l}\text { 1990Q3 - } \\
\text { 1992Q2 }\end{array}$ & $\mathbf{0 . 3 1}$ & $\mathbf{0 . 2 6}$ & $\mathbf{0 . 2 4}$ \\
\hline $\begin{array}{l}\text { 2001Q2 - } \\
\text { 2003Q2 }\end{array}$ & $\mathbf{0 . 3 4}$ & $\mathbf{0 . 3 1}$ & $\mathbf{0 . 2 8}$ \\
\hline $\begin{array}{l}\text { 2007Q4 - } \\
\text { 2010Q4 }\end{array}$ & $\mathbf{0 . 4 5}$ & $\mathbf{0 . 5 0}$ & $\mathbf{0 . 4 6}$ \\
\hline & FPLTU, 15-24 & FPLTU, 25-54 & FPLTU, 55-64 \\
\hline 1981Q1 - & 0.24 & 0.34 & 0.46 \\
1983Q1 & 0.28 & 0.37 & 0.42 \\
\hline $\begin{array}{l}\text { 1990Q3 - } \\
\text { 1992Q2 }\end{array}$ & 0.23 & 0.31 & 0.27 \\
\hline $\begin{array}{l}\text { 2001Q2 - } \\
\text { 2003Q2 }\end{array}$ & 0.40 & 0.47 & 0.44 \\
\hline 2007Q4 - & & & \\
2010Q4 & & & \\
\hline
\end{tabular}

Source: USA_UDUR.xlsx

This data shows that in general there is greater volatility in the proportion of long term unemployment for younger males than younger females; middle aged and older females have higher volatility than the respectively aged males, except in the Great Recession. It is also clear that there was a big jump in volatility of the proportion of long term unemployment during the Great Recession for both males and females for all age groups. The one exception is that for older females the early 1980s was worse that the Great Recession. Figures 22a and 22b show these measures of volatility. 
Figure 22a: Volatility in the Proportion of Long Term Unemployment in Four Recessions by Age (Coefficients of Variation)

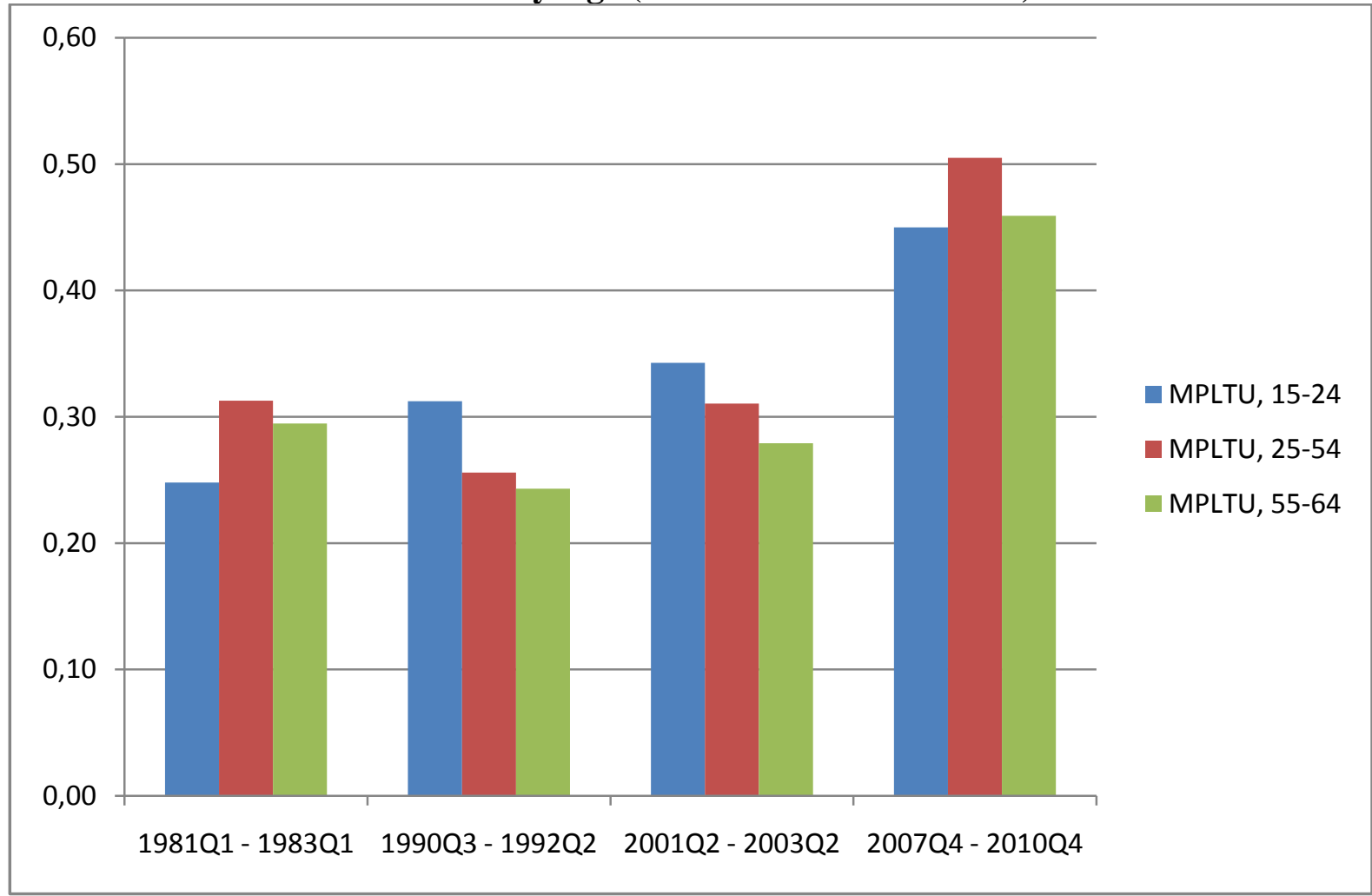

Figure 22a: Volatility in PLTU in Four Recessions by Age (Coefficients of Variation)

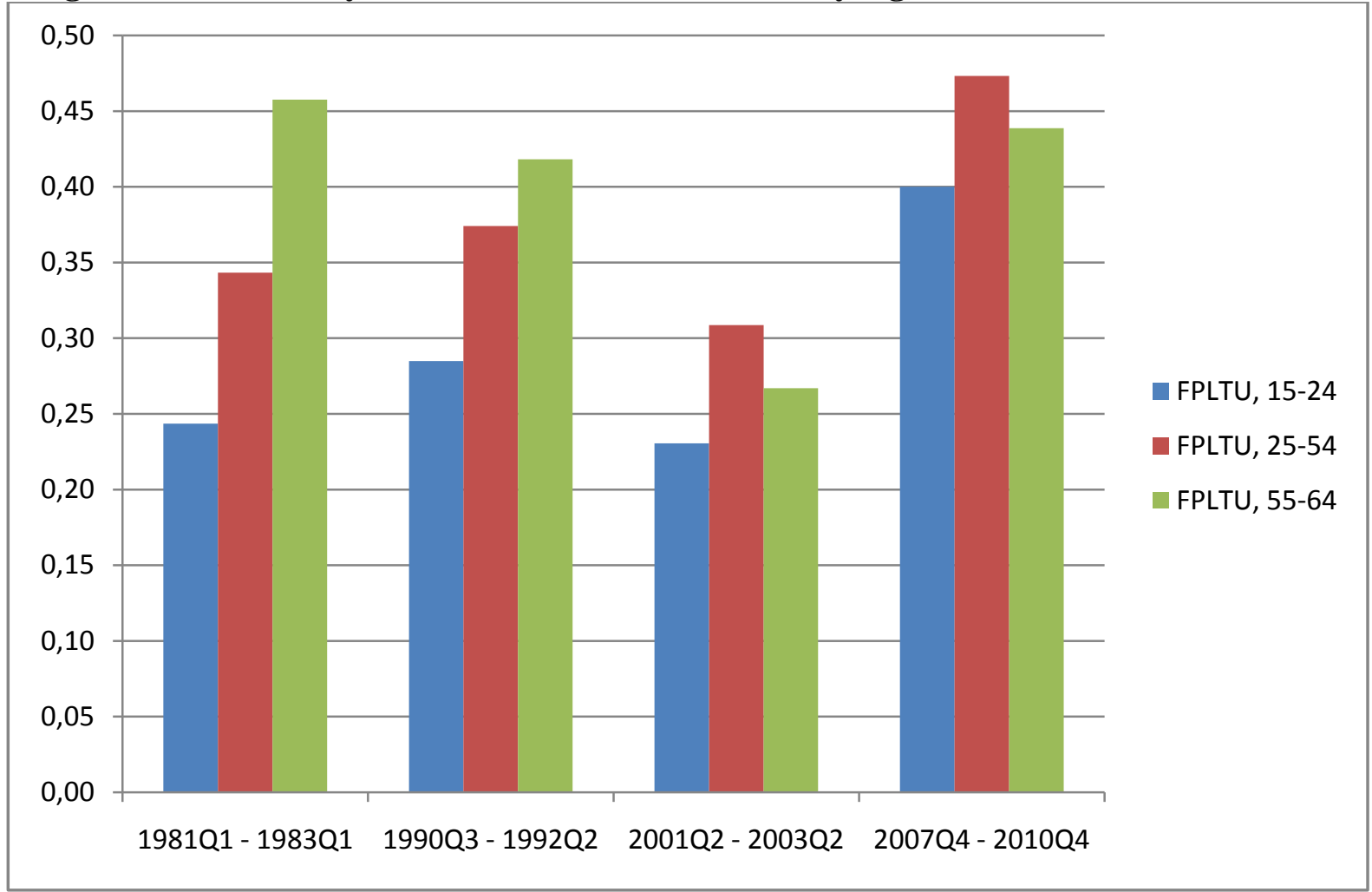

Source: USA_UDUR.xlsx 
When we calculated a thirteen quarter moving coefficient of variation we found that it was more volatile in the 1980s recession than the recessions of the early 1990s or the early 2000s. However, the Great Recession saw a huge increase in the volatility, much larger than in all the previous recessions since 1976. It is interesting to note that the although the volatility is generally similar for males and females, there is a bigger increase for females in the 1990s recession, and then a huge jump in the Great Recession for both males and females, see Figure 23.

Figure 23: Volatility of the Proportion of Long Term Unemployment

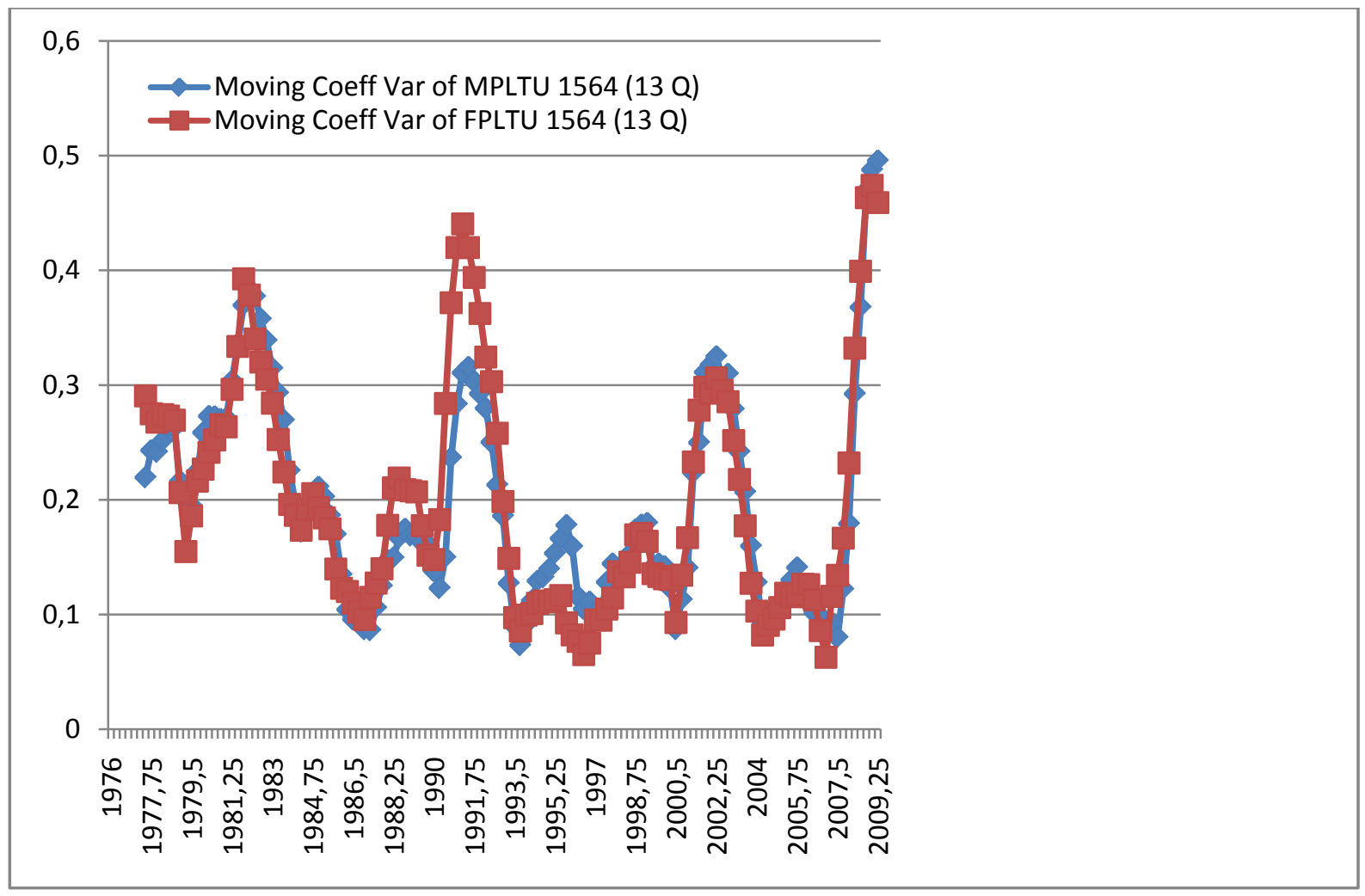

Source: USA_UDUR.xlsx 
Table 11: Age Distribution by Gender, Long Term Unemployment

\begin{tabular}{|c|c|c|c|c|}
\hline & $\begin{array}{c}\% \\
\text { Increase } \\
1981.0- \\
1983.0\end{array}$ & $\begin{array}{c}\% \\
\text { Increase } \\
1990.5- \\
1992.25\end{array}$ & $\begin{array}{c}\% \\
\text { Increase } \\
2001.25- \\
2003.25\end{array}$ & $\begin{array}{c}\% \\
\text { Increase } \\
2007.75 \\
-2010.75\end{array}$ \\
\hline MNLTU 1524 & 101.4 & 205.6 & 235.3 & 294.4 \\
\hline MPLTU 1524 & 69.0 & 123.8 & 170.4 & 151.5 \\
\hline FNLTU 1524 & 82.6 & 263.7 & 140.4 & 309.4 \\
\hline FPLTU 1524 & 53.1 & 221.1 & 86.6 & 148.8 \\
\hline MNLTU 2554 & 201.4 & 158.2 & 234.6 & 617.2 \\
\hline MPLTU 2554 & 75.2 & 61.8 & 110.8 & 223.8 \\
\hline FNLTU 2554 & 151.8 & 187.7 & 169.6 & 484.5 \\
\hline FPLTU 2554 & 71.4 & 136.7 & 94.8 & 188.9 \\
\hline MNLTU 5564 & 158.9 & 179.5 & 364.6 & 683.6 \\
\hline MPLTU 5564 & 43.6 & 58.0 & 135.0 & 162.7 \\
\hline FNLTU 5564 & 84.9 & 360.1 & 262.3 & 544.3 \\
\hline FPLTU 5564 & 34.5 & 234.9 & 89.6 & 173.4 \\
\hline
\end{tabular}

Source: USA_UDUR.xlsx

Table 11 provides an interesting breakdown by age and gender: in general, there is bigger increase for males than females, except in the 1990s recession when females of all age groups had substantially larger increases than males. In the Great Recession, the percentage increase in numbers in long term unemployment (NLTU) were much larger (for all groups) than in the previous recessions. However, in the Great Recession the percentage increase in the proportion of long term unemployment (PLTU) was in general greater than for the earlier recessions except for the age group 15-24. This is because there was a much larger percentage increase in the number of young unemployed in the Great Recession compared to earlier recessions.

Aaronson et al. (2010) provide a breakdown of the long term unemployed in terms of their background characteristics. They find that, not surprisingly, the less educated, blacks and Hispanics are over-represented in the ranks of the long term unemployed. In the Great Recession the long term unemployed were more likely to come from professional and business services and finance and insurance, and real estate relative to the recession of the 1980s. They find that as the labour force has aged, the average duration has increased. They also find that exit probabilities out of unemployment have driven the increased 
unemployment in the present recession. They also argue that the extension of unemployment insurance benefits in the US led to an increase in unemployment duration. However, since the UI benefits were increased because of the increased unemployment and long term unemployment the causation also runs in the opposite direction. It is still too early to substantiate their statement that the UI benefits extension can explain "10-25 percent of the total increase” (Aaronson et al., 2010, p. 40) in average duration since July 2008.

\section{What explains the increases in long term unemployment}

As discussed earlier, an increase in the unemployment rate leads after a lag to an increase in long term unemployment. When an economy is hit by a negative shock, there is initially an increase in the inflows into the unemployment stock. As the newly unemployed join the unemployed stock, some of the existing unemployed find it more difficult to find work (assuming that the number of vacancies remains constant). Hence there is an increase in the numbers of long term unemployed (NLTU). For example, if all the exits from unemployment were of (say) the new entrants into the unemployment stock, then the remainder of the unemployed stock would "become older", that is have longer durations. If there was a big increase in inflows, there would be an initial decrease in the proportion of long term unemployment (PLTU), but after some time PLTU would increase. In general, what happens in a recession is that along with the initial jump in inflows into the unemployment stock, the probability of finding a job falls (as there has been a fall in labour demand) so that the exit probabilities (or hazards) fall. Hence there is an increase in the numbers of long term unemployed, and then slowly an increase in the proportion of long term unemployment.

In an interesting paper Aaronson et al. (2010) carry out a detailed study on US data and find a close relationship between the long term unemployment and the unemployment rate. They find that there was a shift in the relationship since 2008.

In the following Figures 24a through $24 \mathrm{~g}$ we see a very close relationship between the proportion of long term unemployment (PLTU) and the lagged unemployment rates in the G7 countries, although the lag between the increases in the unemployment rate and the increases in the proportion of long term unemployment (PLTU) vary from country to country. In our econometric analysis using panel data we will allow for this heterogeneity. 
Figure 24a: The Relationship between PLTU and the Unemployment Rate, USA

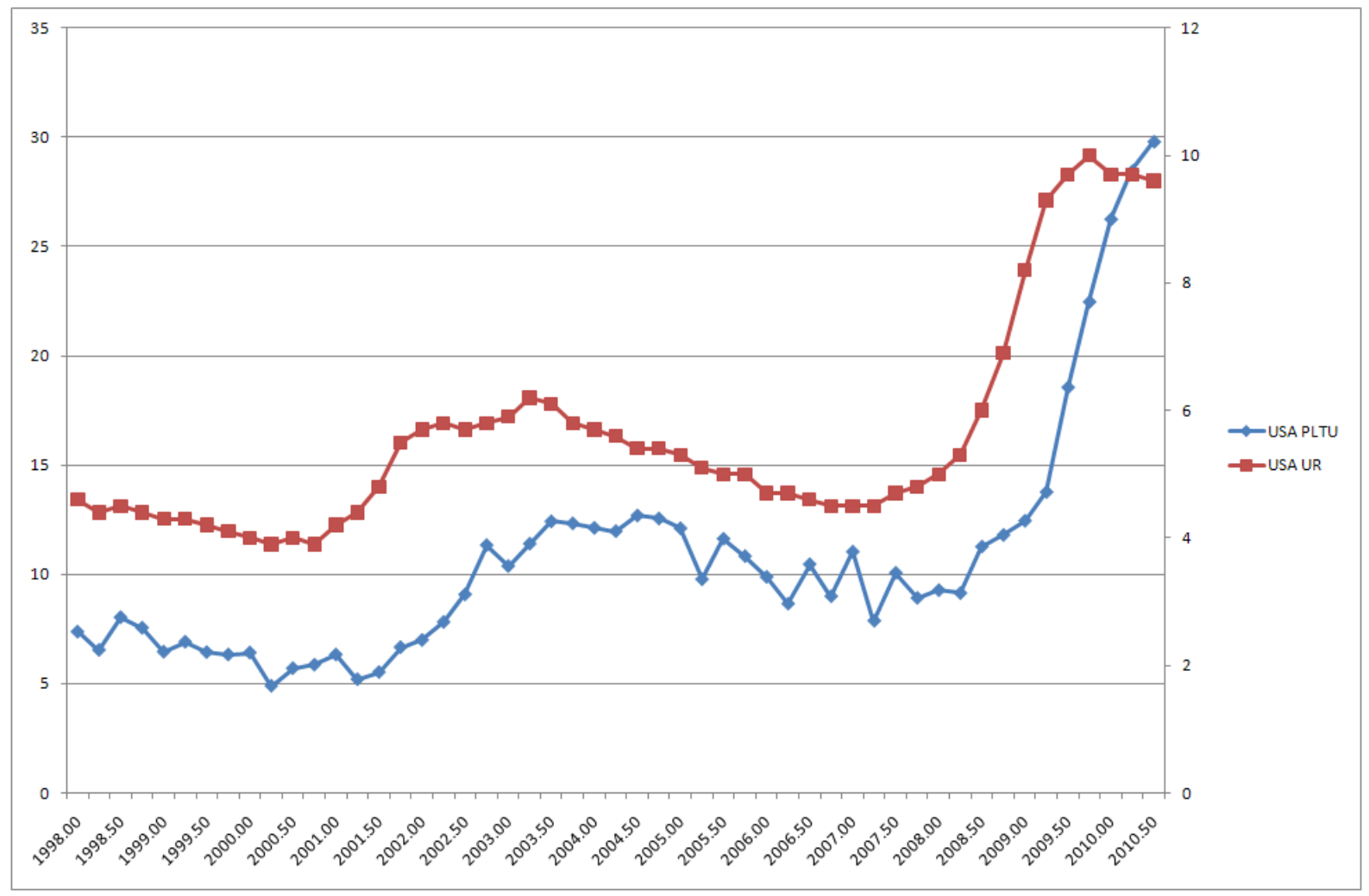

Figure 24b: The Relationship between PLTU and the Unemployment Rate, Canada

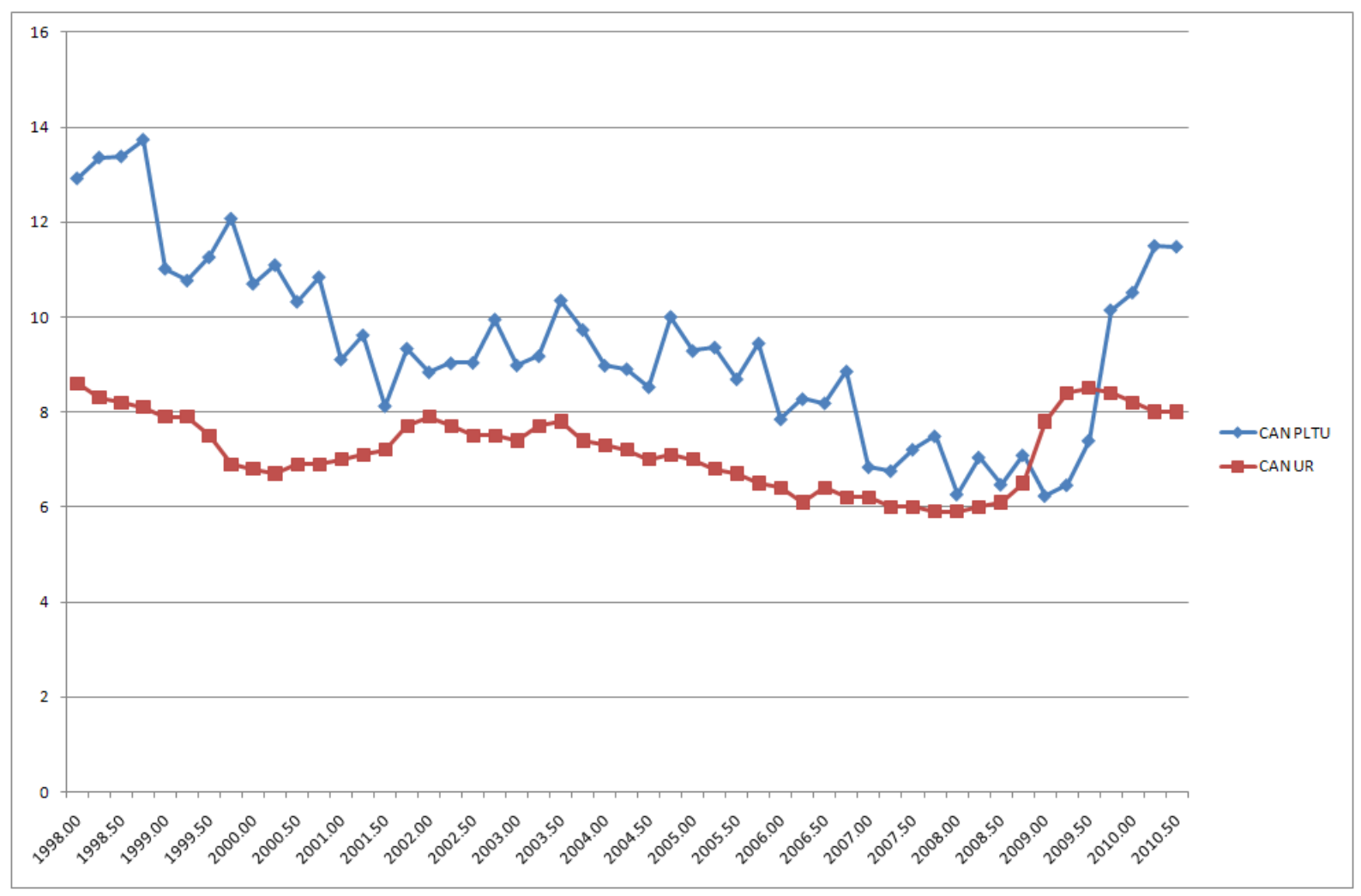


Figure 24c: The Relationship between PLTU and the Unemployment Rate, UK

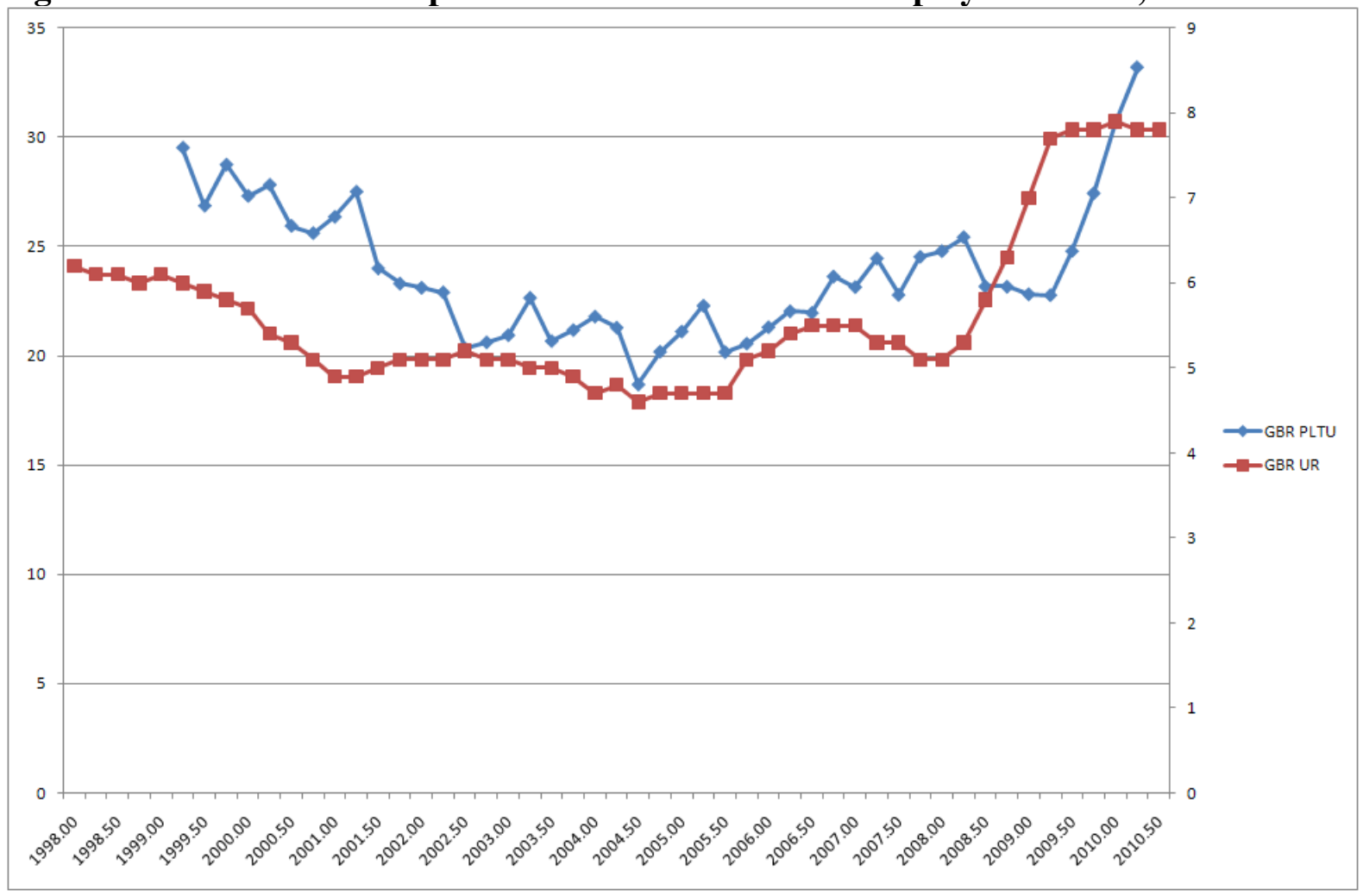

Figure 24d: The Relationship between PLTU and the Unemployment Rate, Italy

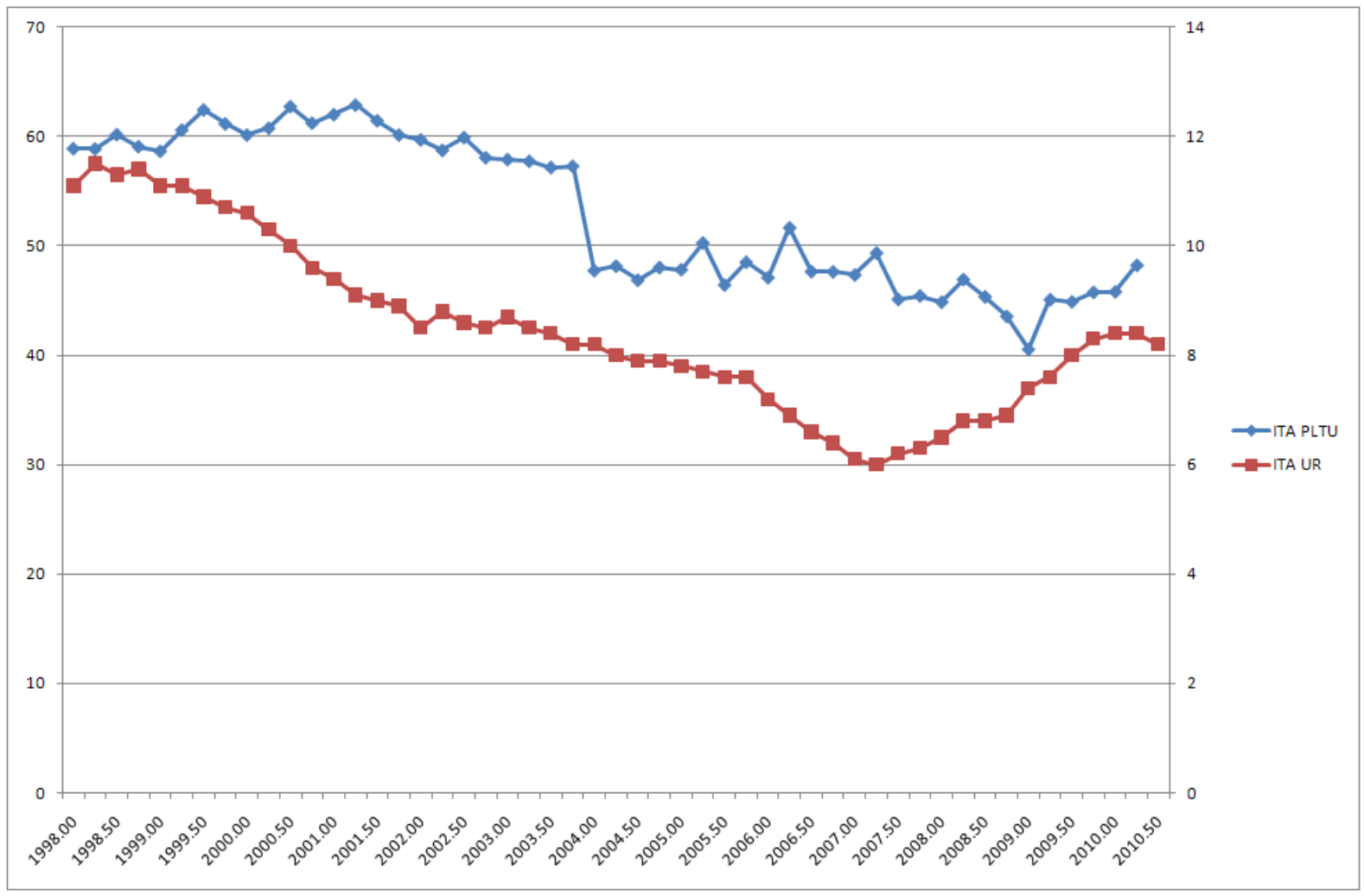

51 
Figure 24e: The Relationship between PLTU and the Unemployment Rate, Japan

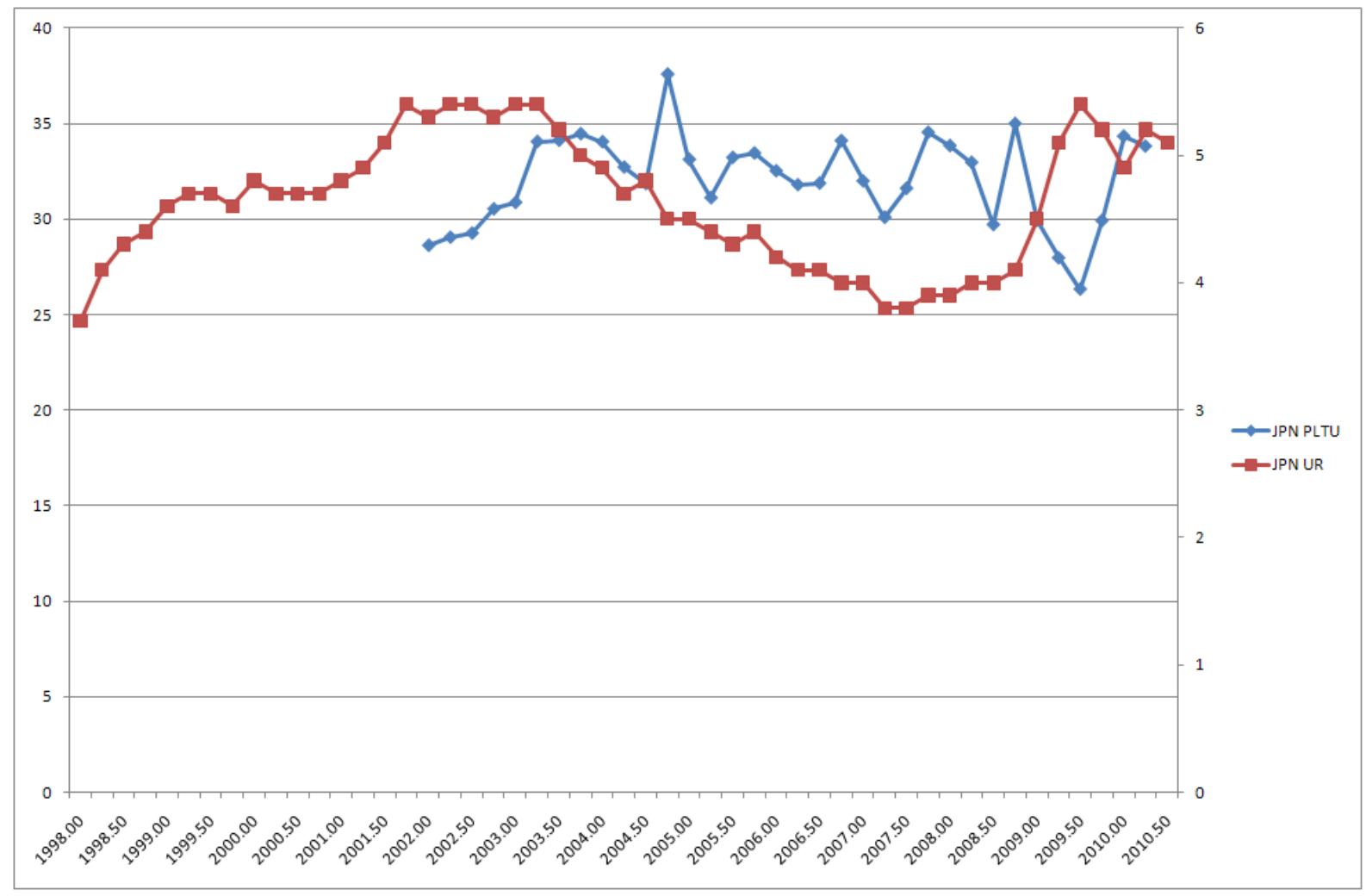

Figure 24f: The Relationship between PLTU and the Unemployment Rate, France

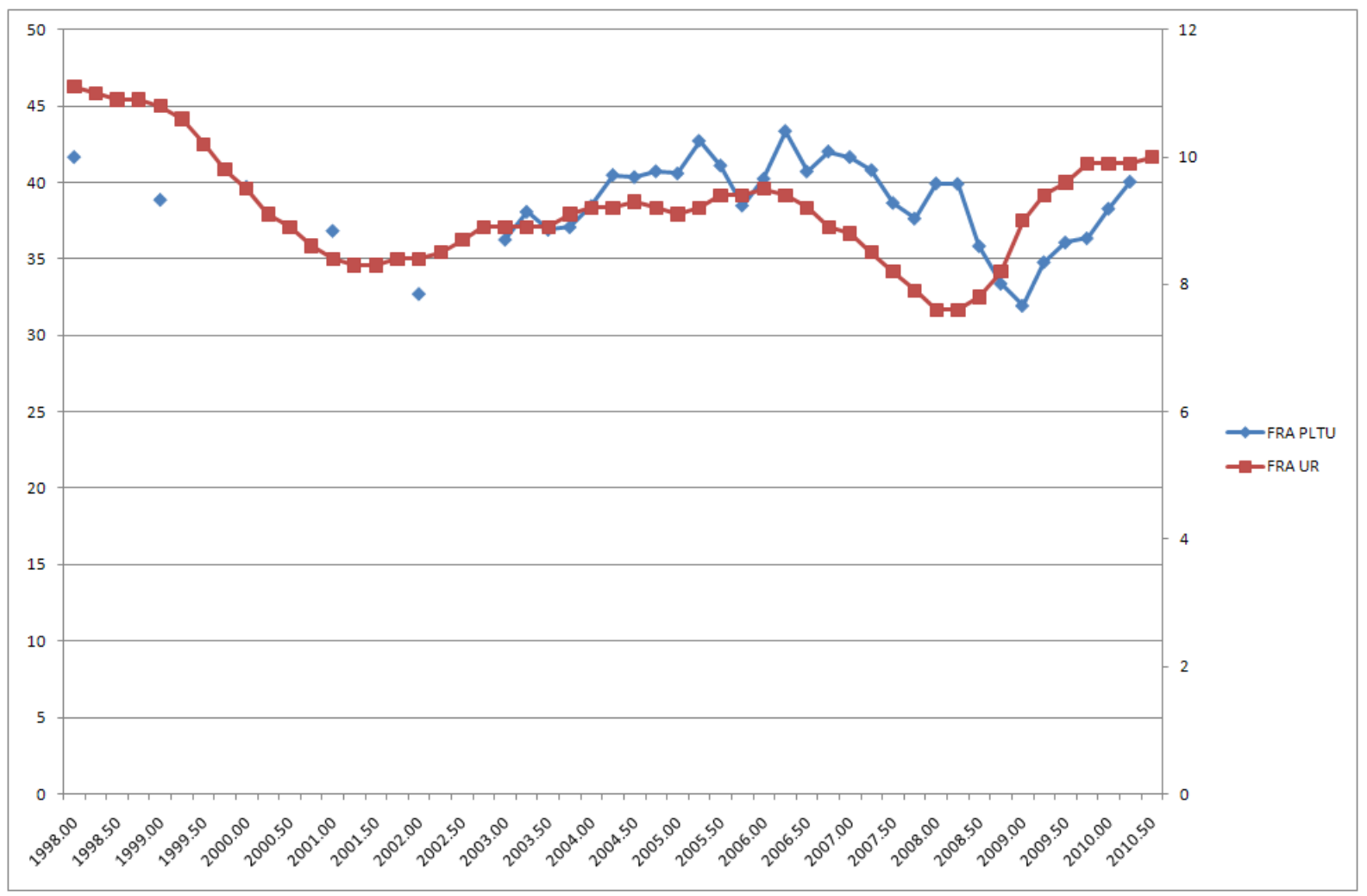


Figure 24g: The Relationship between PLTU and the Unemployment Rate, Germany

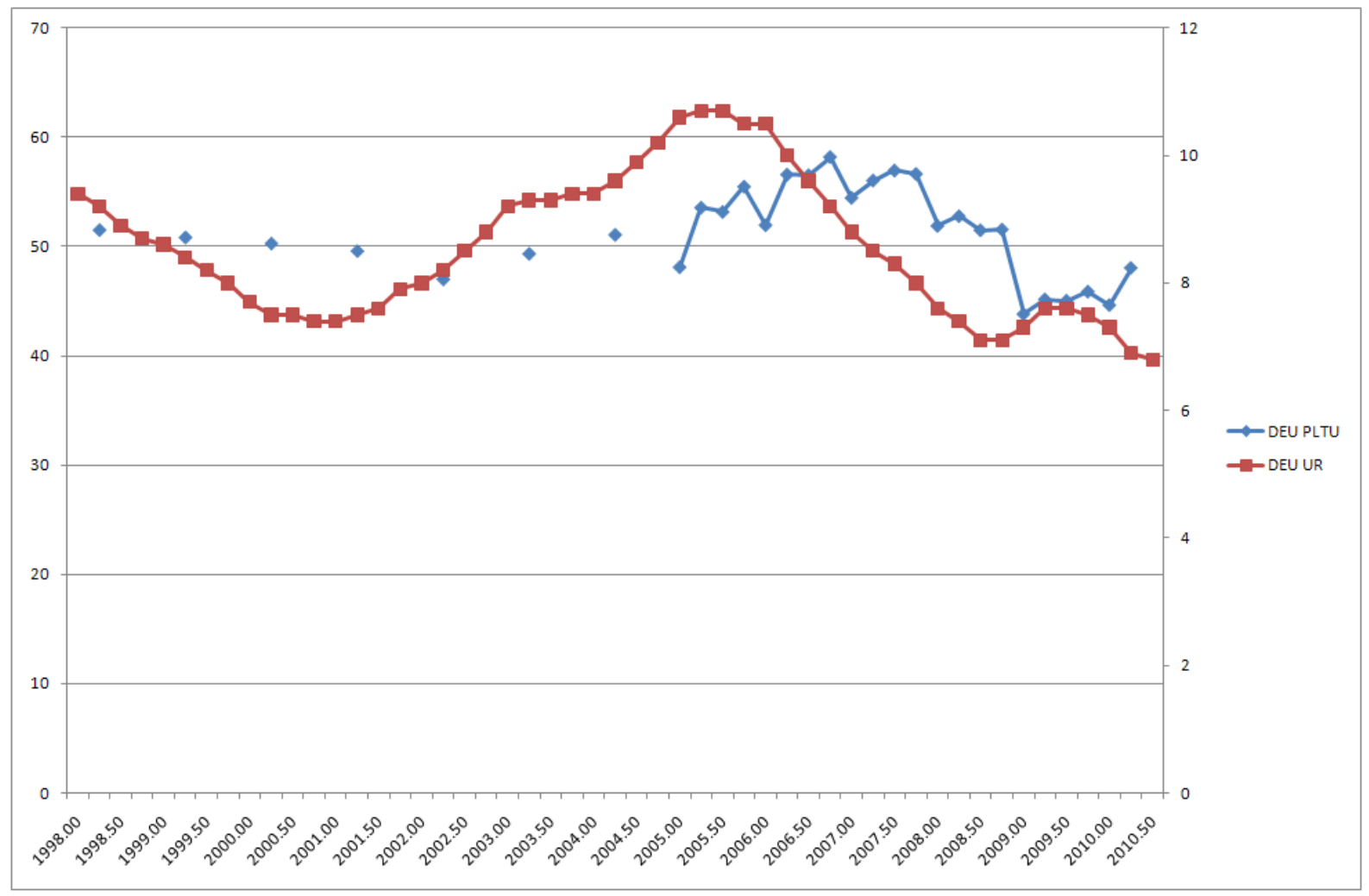

Source: PLTU and UR, G7.xls

Note: Except for Figure 24b, all others have different scales for UR and PLTU.

\section{Econometric Analyses}

\section{(a) OECD Panel Data}

There have been earlier studies that have estimated aggregate functions for the incidence of long term unemployment (PLTU) on lagged unemployment rates, see Guichard and Rusticelli (2010), Jackman and Layard (1991), Chapman, Junankar, and Kapuscinski (1992), Junankar and Kapuscinski (1991). For this study, we have used quarterly data for a panel of OECD countries to estimate the following function:

$$
P L T U_{i, t}=\beta_{0}+\sum_{j} \beta_{j} U R_{i, t-j}+\sum_{j} \gamma_{j} P L T U_{i, t-j}
$$


Where $P L T U_{i, t}$ is the proportion of long term unemployment in country i at time t, $U R_{i, t-j}$ is the unemployment rate for country $\mathrm{i}$ at time $\mathrm{t}-\mathrm{j}$, and $P L T U_{i, t-j}$ is the lagged dependent variable. To avoid problems of endogeneity of the unemployment rate, we have only used lagged terms (pre-determined variables). Since both the unemployment and long term unemployment rates are bounded between zero and one they cannot (by definition) be nonstationary. As such, we did not test for stationarity. In any case, the length of the time series is too small as the power of stationarity tests is very low.

We estimated this model using quarterly data for persons (males and females) for the OECD countries as an unbalanced sample, as a pooled regression and as a fixed effects panel regression, see Table 12 . We initially ran regressions with eight lags on the unemployment rate and on the lagged dependent variables. We imposed zero restrictions on the lags from 3 to 8 periods on the unemployment rate and from 5 to 8 lags on the dependent variable and we could not reject the restrictions. We then estimated the equation with only two lags on the unemployment rate and four lags on the dependent variable and the equation performed well with most of the variables being significantly different from zero. Again, we tested to see if the unemployment rates (as a set) and the lagged PLTUs were statistically significant by testing zero restrictions: we rejected the zero restrictions. We then tested to see if the parameters of the model were stable after the Great Recession by introducing a dummy variable equal to zero until 2007 Q3 and 1 thereafter (interacted with the right hand side variables). We rejected these zero restrictions, hence there appears to have been a break in the relationship between PLTU and unemployment rates and lagged dependent variables. These results show that the lagged unemployment rates are very significant, and the lagged dependent variable is large and very significant. This suggests that it would take very long to lower the percentage of long term unemployment, even after the unemployment rates come down. $^{10}$

\footnotetext{
${ }^{10}$ We tested for the robustness of these estimates by eliminating one country at a time from our sample. These results suggest that they are quite sensitive to the countries excluded from the sample. These results are available on request from the author.
} 
Table 12 Pooled and Fixed Effects Regressions on Quarterly Data (Persons)

\begin{tabular}{|c|c|c|}
\hline & $\begin{array}{l}(1) \\
\text { pltu } \\
\text { Pooled }\end{array}$ & $\begin{array}{l}\text { (2) } \\
\text { pltu } \\
\text { Fixed Effects }\end{array}$ \\
\hline l1ur & $\begin{array}{l}1.086^{* *} \\
(3.76)\end{array}$ & $\begin{array}{r}0.180 \\
(0.64)\end{array}$ \\
\hline 12ur & $\begin{array}{l}-0.992 * * * \\
(-3.43)\end{array}$ & 0.478 * \\
\hline l1pltu & $\begin{array}{c}0.748^{* * *} \\
(23.29)\end{array}$ & $\begin{array}{c}0.593^{* * *} \\
(18.88)\end{array}$ \\
\hline 12pltu & $\begin{array}{l}-0.0289 \\
(-0.72)\end{array}$ & $\begin{array}{l}-0.0496 \\
(-1.34)\end{array}$ \\
\hline 13pltu & $\begin{array}{l}0.0879 * * \\
(2.25)\end{array}$ & $\begin{array}{l}0.0768 \text { ** } \\
(2.13)\end{array}$ \\
\hline 14pltu & $\begin{array}{l}0.176 * * * \\
(5.79)\end{array}$ & $\begin{array}{l}0.195 * * * \\
(6.80)\end{array}$ \\
\hline$q 2$ & $\begin{array}{l}1.024 * \star \star \\
(4.21)\end{array}$ & $\begin{array}{l}0.936 * * * \\
(4.17)\end{array}$ \\
\hline q3 & $\begin{array}{c}0.158 \\
(0.66)\end{array}$ & $\begin{array}{l}0.190 \\
(0.86)\end{array}$ \\
\hline q4 & $\begin{array}{l}0.865 * * * \\
(3.48)\end{array}$ & $\begin{array}{l}0.819 * * * \\
(3.56)\end{array}$ \\
\hline gfc & $\begin{array}{l}-1.141^{* *} \\
(-2.16)\end{array}$ & $\begin{array}{l}-1.318^{* *} \\
(-2.57)\end{array}$ \\
\hline gfcllur & $\begin{array}{l}-1.267 * \star * \\
(-2.98)\end{array}$ & $\begin{array}{l}-1.424 * \star * \\
(-3.52)\end{array}$ \\
\hline gfcl2ur & $1^{1.692 * * *}$ & $\begin{array}{l}1.823 * * * \\
(4.26)\end{array}$ \\
\hline gfcl1pltu & $\begin{array}{l}0.131^{* *} \\
(2.20)\end{array}$ & $\begin{array}{l}0.0720 \\
(1.29)\end{array}$ \\
\hline gfcl2pltu & 0.0276 & 0.0607 \\
\hline gfcl3pltu & $-0.124^{*}$ & -0.101 \\
\hline gfcl4pltu & $\begin{array}{l}(-1.66) \\
-0.0912 \\
(-1.58)\end{array}$ & $\begin{array}{l}(-1.47) \\
-0.0812 \\
(-1.49)\end{array}$ \\
\hline _cons & $\begin{array}{l}-0.610^{* *} \\
(-2.12)\end{array}$ & $\begin{array}{r}0.356 \\
(0.69)\end{array}$ \\
\hline $\mathrm{N}$ & 1343 & 1343 \\
\hline
\end{tabular}

Equation 1: $\mathrm{F}(16,1326)=2547.74$

Adj R-squared $=0.9681$

Tests for Structural Break: F( 7, 1326) $=11.69$; Prob $>F=0.0000$

Equation 2: R-sq:

within $=0.8113$

between $=0.9804$

overall $=0.9562$

Tests for Structural Break: F( 7, 1297) $=9.48$; Prob $>F=0.0000$ 
Guichard and Rusticelli estimate a model on an unbalanced sample of OECD countries allowing for some institutional variables. However, they have used averaged data (three year moving average for the unemployment rate ${ }^{11}$ ), and curiously in these estimations reported in Tables 2 and 3 they do not include lagged long term unemployment (which is large in magnitude and significant for most countries in Table 1). Also given that most of the institutional variables are almost constant over time, it is not clear what the coefficients mean. Their results suggest that there is a positive association between long term unemployment and Employment Protection Legislation, and negative relation with Long term unemployment benefits. Also as mentioned earlier, variables like duration of unemployment benefits are likely to be endogenous and hence should be treated as such in the estimations.

Our regression results (Table 12) support the earlier argument that the percentage of long term unemployment is determined by lagged unemployment rates and lagged dependent variable $^{12}$. The data for the G7 countries provided a visual support for this model in Figures 24a through 24g (see above).

Ideally our model should be extended to allow for a range of other variables, including employment protection, unemployment benefit duration (which is likely to be endogenous), active labour market policies (again likely to be endogenous). In some further analysis, reported below, we have attempted to control for some of these variables.

\section{(b) Econometric Analysis using differences data}

We explored the effects of some institutional variables like Employment Protection Legislation and the impact of unemployment benefits (replacement rates) on the increases in long term unemployment over different recessions. We used a pooled data set of the increases in long term unemployment for each country in each recession (2001 and 2007 recessions ${ }^{13}$ ). Unfortunately the OECD data on institutional variables is only available on an annual basis,

\footnotetext{
${ }^{11}$ The justification given by Guichard and Rusticelli (2010) for using a three year moving average of the unemployment rate (on annual or quarterly data?) was essentially to save degrees of freedom, but they lose the dynamics of long term unemployment. From their account on page 13, it appears that the estimates are based on using Zellner's SURE estimation method on each country equation treated like a separate equation but imposing the same coefficients on the independent variables (did they test the restrictions?), with some countries that would have very few observations. It would seem sensible to treat their results with some caution.

${ }^{12}$ Guichard and Rusticelli (2010) estimate similar equations for some OECD countries (country by country). In many cases they obtain insignificant coefficients. (It is not clear if they used quarterly or annual data.)

${ }^{13}$ For most countries the data did not extend to earlier recessions.
} 
and that too is such that there is little variation over time for these variables for most countries. In order to experiment on the effects of these institutional variables on long term unemployment, we estimated equations for the increase in long term unemployment as a function of the unemployment rate and the average Employment Protection Level (EPL) and the average Gross Replacement Rate (ub_grr). We tried several alternative metrics for the increase in long term unemployment rate: the percentage increase in NLTU (PNLTU), the percentage increase in PLTU (PIPLTU), and the percentage point increase in PLTU (PPTLTU). Similarly, we tried alternative measures of unemployment: the average unemployment during each recession, the percentage increase in the unemployment rate, and the percentage point increase in the unemployment rate. We also tested to see if the Great Recession was significantly different from the 2001 recession, by introducing a zero-one dummy for the Great Recession and interacting it with all the right hand side variables and tested zero restrictions on these variables.

In Table 13 we present the results for these regressions. We have alternatively used as dependent variables the percentage increase in the proportion of long term unemployment (pipltu), the percentage point increase in the proportion of long term unemployment (pptpltu), and the percentage increase in the numbers of long term unemployed (pnltu) (the increases being measured over the period 2001 Q2 to 2004 Q 2 and over the period of the Great Recession, 2007 Q4 to 2010 Q3. We regressed them respectively on the percentage increase in the unemployment rate (pi_ur), the percentage point increase in the unemployment rate (ppt_ur). In addition, we used the averages of the Employment Protection Level (epl) and the Unemployment Benefit Gross Replacement Rate (ub_grr). As mentioned earlier these two variables were based on annual data that did not vary much from year to year.

As we can see in Table 13, the increase in the unemployment rate (measured in either way) was very significant. In all cases the employment protection variable was not statistically significant (even at the ten percent level), while the replacement rate was only significant at the ten percent level for the percentage point increase in the proportion of long term unemployment, but with a negative sign. In other words, the higher the replacement rate the lower the percentage point increase in the proportion of long term unemployment. Further, the EPL variable when interacted with the dummy for the Great Recession was negative but not significant even at the ten percent level for any of the dependent variables. The Great Recession dummy interacted with the replacement rate was positive and statistically 
significant only in the case of dependent variable pptpltu, but only at the ten percent level. However, since we were unable to reject the zero restrictions on structural stability there is no link between the replacement rate and the dependent variables.

In other words, these regressions suggest that the increase in unemployment rate significantly increases long term unemployment. In general, when we tested for structural stability we were unable to reject the zero restrictions at the five percent level. In other words, there was no structural break between the recession of the early 2000s and the Great Recession for increases in long term unemployment. Note, however, that we found a significant structural break when we used time series data for levels of the percentage of long term unemployment.

Table 13: Cross Country Regressions for Two Recessions

\begin{tabular}{|l|c|c|c|}
\hline & 1 & 2 & 3 \\
\hline & pipltu & pptpltu & pnltu \\
\hline & -13.24 & 0.111 & -16.57 \\
\hline ub_grr & $(-0.99)$ & $(0.11)$ & $(-1.04)$ \\
\hline & -0.729 & $-0.149^{*}$ & -0.71 \\
\hline pi_ur & $(-1.51)$ & $(-1.75)$ & $(-1.21)$ \\
\hline & $1.165^{* *}$ & & $2.337^{* * *}$ \\
\hline GFC & $(2.35)$ & & $(4.01)$ \\
\hline & -14.94 & -10.16 & -26.27 \\
\hline GFC_piur & $(-0.25)$ & $(-1.31)$ & $(-0.32)$ \\
\hline & -0.458 & & 0.851 \\
\hline GFC_epl & $(-0.90)$ & & $(1.18)$ \\
\hline & -13.83 & -4.551 & -25.23 \\
\hline GFC_ub_grr & $(-0.54)$ & $(-1.65)$ & $(-0.69)$ \\
\hline & $(1.351$ & $0.571^{* *}$ & 1.122 \\
\hline ppt_ur & & $(2.56)$ & $(0.64)$ \\
\hline GFC_pptur & & $2.764^{* *}$ & \\
\hline & & $(2.49)$ & 47.83 \\
\hline _cons & 38.19 & -0.516 & $(-0.44)$ \\
\hline & $(1.19)$ & $(0.87)$ & \\
\hline N & 43 & 43 & \\
\hline
\end{tabular}

\section{Notation:}

Pipltu: Percentage Increase in Proportion of Long Term Unemployment (PLTU) Pptpltu: Percentage Point Increase in PLTU 
Pnltu: Percentage increase in the numbers of long term unemployed (NLTU)

Epl: Employment Protection Legislation (average for each period)

Ub_grr: Unemployment Benefit gross replacement rate (average for each period)

Pi_ur: Percentage increase in Unemployment Rate

Ppt_ur: Percentage point increase in Unemployment Rate

GFC: Dummy for Global Financial Crisis (zero for first period, 1 for second period)

t statistics in parentheses

$* \mathrm{p}<0.1, * * \mathrm{p}<0.05, * * * \mathrm{p}<0.01$

\section{Equation 1:}

$\mathrm{F}(7,35)=6.27$

Prob $>\mathrm{F}=0.0001$

R-squared $=0.5635$

Structural Stability Tests: Cannot reject zero restrictions

$\mathrm{F}(4,35)=0.74$

Prob $>\mathrm{F}=0.5686$

\section{Equation 2:}

$\mathrm{F}(7,35)=9.74$

Prob $>F=0.0000$

R-squared $=0.5229$

Structural Stability Tests: Reject zero restriction only at $10 \%$ significance levels.

$\mathrm{F}(4,35)=2.18$

Prob $>F=0.0921$

\section{Equation 3:}

$\mathrm{F}(7,35)=15.44$

Prob $>\mathrm{F}=0.0000$

R-squared $=0.8785$

Structural Stability Tests: Cannot reject zero restrictions

$\mathrm{F}(4,35)=1.36$ 
Prob $>F=0.2661$

The results using fixed effects estimation on the same data set gave very similar results.

\section{(c) Econometric Analyses of Time Series Data, USA}

In this section we use fairly long time series quarterly data for the United States and for the United Kingdom. Again our model is based on estimating the proportion of long term unemployment (PLTU) as a function of lagged unemployment rates (UR) and lagged dependent variables, a measure of openness of the economy (Open) defined as (Exports + Imports)/GDP), and a dummy for the Global Financial Crisis interacted with all the independent variables. The results for both countries suggest that there is a significant relationship between the lagged unemployment rates (UR t-i) and the proportion of long term unemployment (PLTU), as well as with lagged dependent variables.

For the USA, we estimated equations for US time series data from 1976 (Q1) to 2010 (Q4). The model was estimated with four lags on UR and four lags on PLTU, with quarterly dummies, a zero-one dummy for the Global Financial Crisis (gfc), and then interacted with all the right hand side variables. The results are provided in Table 14. Following Hendry's method of General to Specific (GeTS), we tested for zero restrictions on the four lags of UR and rejected the restrictions, and for zero restrictions on four lags on PLTU and rejected these restrictions; we tested for zero restrictions on the GFC variable and interacted with all the other variables and rejected the zero restrictions implying that there was a structural break after the GFC.

Our results suggest that the proportion of long term unemployment (PLTU) increases with the unemployment rate and that the higher the previous periods PLTU, the higher is the present PLTU. In other words, when the unemployment rate increases, PLTU increases for a long time afterwards (there is persistence in the series). We find that the more open the US economy becomes the larger the proportion of long term unemployment. Note that Open is positive and significant. This requires further investigation. The results suggest that the global crisis significantly altered the relationship between PLTU and lagged unemployment rates and lagged PLTU. 
Table 14: US Time Series Regressions, 1976 Q1-2010Q4

\begin{tabular}{|c|c|}
\hline & PLTU \\
\hline \multirow[t]{2}{*}{$\mathrm{UR}(\mathrm{t}-1)$} & 0.0005 \\
\hline & $(0.002)$ \\
\hline \multirow[t]{2}{*}{$\mathrm{UR}(\mathrm{t}-2)$} & $0.0085 *$ \\
\hline & $(0.004)$ \\
\hline \multirow[t]{2}{*}{$\mathrm{UR}(\mathrm{t}-3)$} & -0.0005 \\
\hline & $(0.005)$ \\
\hline \multirow[t]{2}{*}{$\mathrm{UR}(\mathrm{t}-4)$} & -0.0025 \\
\hline & $(0.003)$ \\
\hline \multirow[t]{2}{*}{ PLTU(t-1) } & $0.7920 * * *$ \\
\hline & $(0.094)$ \\
\hline \multirow[t]{2}{*}{ PLTU(t-2) } & $0.2435^{* *}$ \\
\hline & $(0.115)$ \\
\hline \multirow[t]{2}{*}{ PLTU(t-3) } & $-0.3883 * * *$ \\
\hline & $(0.113)$ \\
\hline \multirow[t]{2}{*}{ PLTU(t-4) } & $0.1528 *$ \\
\hline & $(0.078)$ \\
\hline \multirow[t]{2}{*}{ gfc } & 0.2011 \\
\hline & $(0.217)$ \\
\hline \multirow[t]{2}{*}{ open } & $0.1342^{* * *}$ \\
\hline & $(0.031)$ \\
\hline \multirow[t]{2}{*}{ gfc*UR(t-1) } & -0.0166 \\
\hline & $(0.016)$ \\
\hline \multirow[t]{2}{*}{ gfc*UR(t-2) } & -0.0003 \\
\hline & $(0.014)$ \\
\hline \multirow[t]{2}{*}{ gfc*UR(t-3) } & 0.0049 \\
\hline & $(0.023)$ \\
\hline \multirow[t]{2}{*}{ gfc*UR(t-4) } & $0.0671^{* * *}$ \\
\hline & $(0.015)$ \\
\hline \multirow[t]{2}{*}{ gfc*PLTU(t-1) } & $-1.2336 * * *$ \\
\hline & $(0.383)$ \\
\hline \multirow[t]{2}{*}{ gfc*PLTU(t-2) } & $-0.7656 * *$ \\
\hline & $(0.373)$ \\
\hline \multirow[t]{2}{*}{ gfc*PLTU(t-3) } & 0.3866 \\
\hline & $(0.400)$ \\
\hline \multirow[t]{2}{*}{ gfc*PLTU(t-4) } & 0.3582 \\
\hline & $(0.350)$ \\
\hline \multirow[t]{2}{*}{ gfc*open } & -1.1337 \\
\hline & $(0.839)$ \\
\hline \multirow[t]{2}{*}{ _cons } & $-0.0470 * * *$ \\
\hline & $(0.010)$ \\
\hline $\mathrm{N}$ & 136 \\
\hline Adj R-squared & 0.9857 \\
\hline
\end{tabular}


Note: Parentheses contain standard errors. The model was estimated with quarterly dummies, but are not presented in the table above.

Test Zero Restrictions on UR (Reject)

$\mathrm{F}(4,113)=15.15$

Prob $>F=0.0000$

Test Zero Restrictions on PLTU (Reject)

$\mathrm{F}(4,113)=64.13$

Prob $>\mathrm{F}=0.0000$

Test Zero Restrictions on PLTU (t-3) and PLTU (t-4) (Reject)

$\mathrm{F}(2,113)=6.36$

Prob $>\mathrm{F}=0.0024$

Test Zero Restrictions on GFC and all interactive terms (Reject)

$\mathrm{F}(10,113)=7.67$

Prob $>\mathrm{F}=0.0000$

We used the estimated model to provide projections for 2011 Q1 to 2012 Q4 for the time paths of the proportion of long term unemployment (PLTU) based on two alternative time paths for the unemployment rate. The first alternative is based on the OECD projections and the second alternative is assuming that the unemployment rate remains constant at $9.0 \%{ }^{14}$. This latter alternative is not meant to imply that we predict that the unemployment rate will remain at this level but simply to provide an alternative path under pessimistic assumptions. These results are provided in Table 15.

Table 15: Projections of the Proportion of Long Term Unemployment

\begin{tabular}{|c|c|c|c|c|}
\hline & UR Projection 1 & PLTU 1 & UR Projection 2 & PLTU2 \\
\hline 2011q1 & 9 & 0.30785 & 9 & 0.30785 \\
\hline 2011q2 & 8.8 & 0.35512 & 9 & 0.35512 \\
\hline $2011 \mathrm{q} 3$ & 8.5 & 0.32706 & 9 & 0.32383 \\
\hline $2011 \mathrm{q} 4$ & 8.3 & 0.31127 & 9 & 0.30628 \\
\hline $2012 \mathrm{q} 1$ & 8 & 0.2847 & 9 & 0.28231 \\
\hline $2012 \mathrm{q} 2$ & 7.8 & 0.32316 & 9 & 0.33159 \\
\hline $2012 \mathrm{q} 3$ & 7.5 & 0.28289 & 9 & 0.30306 \\
\hline $2012 \mathrm{q} 4$ & 7.2 & 0.26475 & 9 & 0.28423 \\
\hline
\end{tabular}

\footnotetext{
${ }^{14}$ We note that the unemployment rate in the USA has gone up from $9.1 \%$ to $9.2 \%$. However, it is not clear at present if that is likely to remain at this level.
} 
It is interesting to see that it takes some time before the proportion of long term unemployment falls even with a declining rate of the unemployment rate. If the unemployment rate remains constant at $9.0 \%$ begins at about the same level before it diverges and remains at much higher levels. See Figure 25 below.

Figure 25: Projections of PLTU for USA

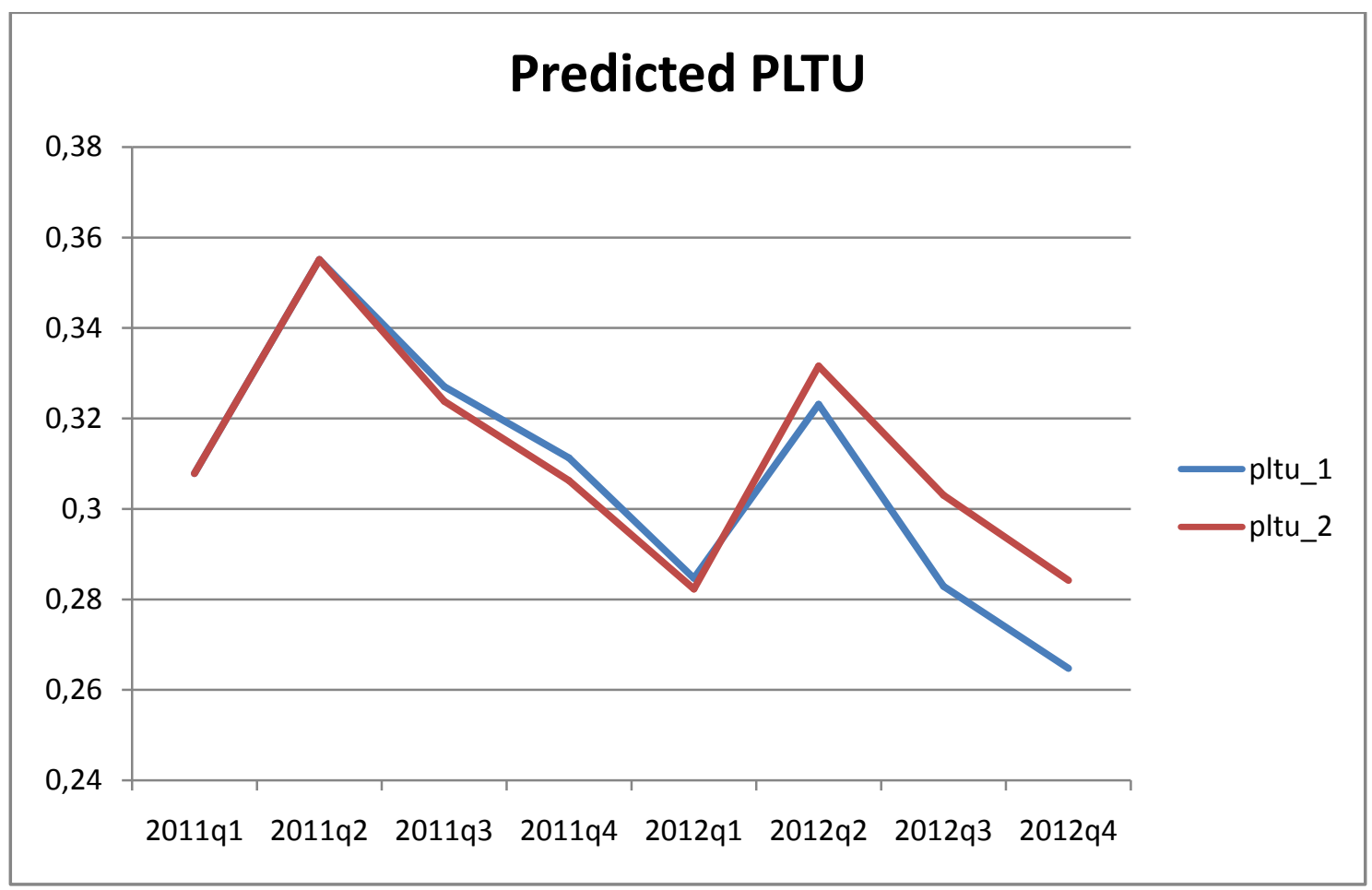

Source: Authors calculations.

(d) Econometric Analyses of Time Series Data,

The results for the UK are based on estimating a similar model for the proportion of long term unemployment (PLTU) using quarterly data from 1992 (Q2) to 2010 Q (2). As for the US we estimated a similar model with four lags on the unemployment rate and on PLTU, on openness of the economy, the GFC (as a zero-one dummy and interacted with all the right hand side variables). In Table 15 we present these results. 
Table 16: UK Time Series (estimated with Quarterly Dummies), 1992 Q2-2010 Q2

\begin{tabular}{|c|c|c|}
\hline & PLTU & PLTU \\
\hline \multirow[t]{2}{*}{$\mathrm{UR}(\mathrm{t}-1)$} & 0.0024 & \\
\hline & $(0.008)$ & \\
\hline \multirow[t]{2}{*}{ UR(t-2) } & 0.0024 & \\
\hline & $(0.013)$ & \\
\hline \multirow[t]{2}{*}{$\mathrm{UR}(\mathrm{t}-3)$} & 0.0189 & $0.0210 * * *$ \\
\hline & $(0.012)$ & $(0.007)$ \\
\hline \multirow[t]{2}{*}{$\mathrm{UR}(\mathrm{t}-4)$} & -0.0094 & -0.0059 \\
\hline & $(0.009)$ & $(0.009)$ \\
\hline \multirow[t]{2}{*}{ PLTU(t-1) } & $0.6861 * * *$ & $0.6835 * * *$ \\
\hline & $(0.146)$ & $(0.076)$ \\
\hline \multirow[t]{2}{*}{ PLTU(t-2) } & -0.0556 & \\
\hline & $(0.173)$ & \\
\hline \multirow[t]{2}{*}{ PLTU(t-3) } & 0.0312 & \\
\hline & $(0.173)$ & \\
\hline \multirow[t]{2}{*}{ PLTU(t-4) } & 0.056 & \\
\hline & $(0.114)$ & \\
\hline \multirow[t]{2}{*}{ gfc } & $5.4269 * *$ & -0.0347 \\
\hline & $(2.416)$ & $(0.109)$ \\
\hline \multirow[t]{2}{*}{ open } & 0.0372 & 0.0302 \\
\hline & $(0.044)$ & $(0.044)$ \\
\hline \multirow[t]{2}{*}{ gfc*UR(t-1) } & $-0.3230 *$ & \\
\hline & $(0.164)$ & \\
\hline \multirow[t]{2}{*}{$\mathrm{gfc}_{\mathrm{C}} * \mathrm{UR}(\mathrm{t}-2)$} & $0.3314^{*}$ & \\
\hline & $(0.191)$ & \\
\hline \multirow[t]{2}{*}{ gfc*UR(t-3) } & -0.1352 & -0.0121 \\
\hline & $(0.096)$ & $(0.017)$ \\
\hline \multirow[t]{2}{*}{$\operatorname{gfc}_{\mathrm{C}} * \mathrm{UR}(\mathrm{t}-4)$} & 0.0519 & 0.0236 \\
\hline & $(0.040)$ & $(0.025)$ \\
\hline \multirow[t]{2}{*}{ gfc*PLTU(t-1) } & $-0.8894^{*}$ & -0.3022 \\
\hline & $(0.520)$ & $(0.326)$ \\
\hline \multirow[t]{2}{*}{ gfc*PLTU(t-2) } & 4.7099* & \\
\hline & $(2.543)$ & \\
\hline \multirow[t]{2}{*}{ gfc*PLTU(t-3) } & $-2.8290 *$ & \\
\hline & $(1.524)$ & \\
\hline \multirow[t]{2}{*}{ gfc*PLTU(t-4) } & $-5.5876 * *$ & \\
\hline & $(2.244)$ & \\
\hline \multirow[t]{2}{*}{ gfc*open } & $-6.8582 * *$ & 0.0795 \\
\hline & $(3.216)$ & $(0.194)$ \\
\hline \multirow[t]{2}{*}{ _cons } & -0.034 & -0.0246 \\
\hline & $(0.032)$ & $(0.031)$ \\
\hline $\mathrm{N}$ & 69 & 69 \\
\hline Adj R-squared & 0.9908 & 0.9902 \\
\hline
\end{tabular}


As earlier, we tested various zero restrictions:

Test Zero Restrictions on UR (Reject)

$\mathrm{F}(4,46)=7.15$

Prob $>\mathrm{F}=0.0001$

Test Zero Restrictions on PLTU (Reject)

$\mathrm{F}(4,46)=23.27$

Prob $>\mathrm{F}=0.0000$

Test Zero Restrictions on UR (t-1) and UR (t-2) (Cannot Reject)

$\mathrm{F}(2,46)=0.28$

Prob $>\mathrm{F}=0.7555$

Test Zero Restrictions on PLTU (t-2) PLTU (t-3) and PLTU (t-4) (Cannot Reject)

$\mathrm{F}(3,46)=0.34$

Prob $>\mathrm{F}=0.7956$

Test Zero Restrictions on GFC and all interactive terms (Cannot Reject)

$\mathrm{F}(10,46)=1.40$

Prob $>F=0.2109$

We rejected the zero restrictions on four lags of UR and on four lags of PLTU. However, we could not reject zero restrictions on the first two lags of UR and on PLTU (t-2) PLTU (t-3) and PLTU (t-4). Similarly, we could not reject the zero restrictions on all the interactive terms of the GFC, hence there does not appear to be a significant structural break for the $U K$. As before, we find that an increase in the unemployment rate leads to an increase in PLTU, and there is persistence (as the lagged PLTU is also significant). However, unlike for the USA, openness does not play a role.

\section{(e) Summary of Econometric Results}

Over the past decade many countries increased labour market flexibility with an increasing number of workers on temporary contracts and flexibility to alter working hours, see IMF (2010). Those on temporary contracts or casual workers would be the first to lose their jobs and hence increase the responsiveness of unemployment to output changes. On the other hand, flexibility of working hours may lead firms to cut working hours rather than laying off workers. Countries that had regulations about severance pay may have had a lower rate of retrenchment, and led firms to use short time working, see Gamberoni, Uexkull, and Weber 
(2011). As a result when the economy recovers, it may lead to a “jobless recovery' for some time.

Overall, the findings of our research are that there are many differences between the impact of the Great Recession on different countries. Countries that faced a significant financial crisis and a collapse of the housing market bubble have had large increases in unemployment and long term unemployment. There was a big fall in employment in the (especially) construction and manufacturing industries. The financial collapse led to an increase in unemployment in the financial and business sector. As a result of these twin shocks labour mobility of the unemployed is likely to be affected: with negative equity in housing, unemployed workers are unlikely to move regionally. With a loss of wealth (in housing and financial assets, including superannuation) there will be a fall in consumer spending which will slow down the recovery of economies. Overall, we find that an increase in unemployment rates leads to an increase in the proportion of long term unemployment (PLTU) for some time, and there is persistence in PLTU. This means that, especially for some countries, there will be a long period of high unemployment and long term unemployment.

\section{Implications for Labour Market Policy}

\section{"Active labour market policy can be a complement but not a substitute to other measures." Calmfors $(1994$, p. 38)}

What this paper has shown is that long term unemployment increases concomitantly with the unemployment rate. Hence, policies that lead to a lowering of the unemployment rate, will after a lag, lead to a lowering of long term unemployment. In the immediate aftermath of the Great Recession most OECD countries introduced crisis measure to stabilise their economies: these policies included significant loosening of monetary policy (interest rates by central banks being lowered to almost zero) and aggressive fiscal policies (increased public expenditure, increased expenditure on active labour market policies, and policies to encourage firms to cut hours rather than fire workers). There is evidence from some countries, e.g. Australia, where these aggressive policies managed to stave off a recession while in other countries the recession was not as deep as it might otherwise have been. 
Germany is an interesting example where the introduction of cutting working hours appears to have helped to prevent an increase in unemployment and long term unemployment. However, as the global crisis appears to have eased many OECD governments have become concerned about increasing government budget deficits and have introduced (as in the UK) major measures to cut back public expenditures. However, as the IMF (2010) says, "Given the additional prospect that unemployment becomes structural, the standard macroeconomic levers-monetary and fiscal policy-remain the primary tools for boosting employment through the impact on economic activity. In countries where unemployment rates remain high and the economy is operating below potential, policy stimulus remains warranted.” (Italics added, p. 70.)

With this in mind, we need to consider Active Labour Market Policies that are currently in use, but with a view to targeting the long term unemployed. This study has shown that there was a great diversity of experience of long term unemployment in different OECD countries. For example, the age distribution of the increases in long term unemployment was such that the US had a very large increase in older people (55 years plus), while in Spain the biggest increase was for the younger unemployed (15-24 year olds), and in Canada the biggest increases were for the young and the old. By gender, in most OECD countries males dominated amongst the long term unemployed and there was an increase of the male proportions during the Great Recession. However, in some countries like Canada and Ireland the male share of long term unemployed fell.

The use of short time working was successful in some countries like Germany and Japan in containing the growth of unemployment and long term unemployment. However, it is probably too late to introduce short time working in other OECD countries as the initial exercise was to prevent workers from being laid off.

The approach to solving or alleviating the problem of unemployment or long term unemployment (LTU) has to influence (a) the demand for labour, (b) the supply of labour, or (c) the functioning of the labour market. In a pure neoclassical economy, the demand for labour is independent of aggregate demand ${ }^{15}$ : it depends simply on firms maximising profits subject to a production function with given input and output prices. Of

\footnotetext{
${ }^{15}$ In a neoclassical model, the labour market always clears. If the Government tries to increase Aggregate Demand by using fiscal policy, in the long run the Aggregate Demand Function shifts back to equate with Aggregate Supply at full employment equilibrium.
} 
course, if the labour market is not perfectly competitive (which it is not) then policies have to influence the way that bargaining takes place in the labour market, affect the information flows between the employer and employees etc. An important question that has to be answered is to what extent aggregate demand policies can affect the demand for labour. Neoclassical economists believe that with competitive markets the only way that employment can be affected is by shifting the production function (i.e. via technological change). Furthermore, we need to know to what extent technological change affects the demand for labour (and the supply of labour). There are some policies that are purely "cosmetic": they simply alter the administrative count of unemployment: they simply redefine the problem. Early retirement schemes, or schemes that shift older unemployed workers from unemployment benefits to old age pensions is one such example.

Note that what happens to the unemployment rate depends on changes to the participation rate. A growth of the economy would help to expand employment, and lower the unemployment rate if the labour force participation rate remains constant. However, we expect the participation rate to increase as the economy picks up and decline as the economy goes into a recession. Note that the faster the productivity growth, the less labour is required and hence employment may not increase rapidly.

A set of possible policies to lower the unemployment rate and the rate of long term unemployment:

(a) Indirect job creation via monetary/fiscal policies to increase aggregate demand. Direct job creation is where the Government increases employment in the public sector, e.g. education, health, etc.

(b) Active Labour Market Policies (ALMPs).

Labour market programs /training / subsidies /counselling / direct job creation programs. Should we worry if we only "reshuffle the queue"?

(c) Reforming the labour market: Deregulation, e.g. changing employment protection legislation; Lower non-wage labour costs, e.g. payroll taxes; Work for the Dole.

(e) Unemployment benefits: Lower them. Decrease duration of benefits.

(g) Restrict Immigration? 
(h) Early retirement policies. Work-sharing by short-time working.

(i) Improve education, training and skills formation.

What is the aim of ALMPs? An obvious one is to increase employment or decrease unemployment. Another one is to increase the efficiency of the operation of the labour market by improving the matching of skills between the unemployed and vacancies (improve the trade-off between inflation and unemployment, or to "cheat the Phillips curve" or to shift the Beveridge $U-V$ curve), i.e. to decrease frictions that may be due to imperfect information. Another important objective may be to improve equity. Thus ALMPs may be targeted at disadvantaged groups, e.g. the Aboriginal people, migrants, the sick and disabled, sole parents, women, the long term unemployed, etc. If the equity issue is taken seriously it means that ALMPs need not decrease aggregate unemployment (increase employment) but simply redistribute (share) unemployment (employment). ALMPs should certainly be targeted at disadvantaged groups, but should also attempt to decrease aggregate unemployment. As many of the OECD economies are still just beginning to recover from the Great Recession, this is only possible if ALMPs are accompanied by measures to increase aggregate demand via fiscal and monetary policy.

Most evaluations of labour market programs, however, are fraught with difficulties. Whether subsidies to employers increase employment and decrease unemployment in aggregate depends on several factors: (a) how sensitive employment is to a small change in the wage (i.e. the elasticity of demand); (b) the extent to which there is deadweight loss (the jobs which would have been created anyway); (c) substitution (the extent to which the target group is helped at the expense of the rest of the unemployed); (d) job displacement (subsidised employers expanding at the expense of non-subsidised employers); (e) the extent to which these programs increase the labour force participation; the so-called registration rate effect, and (f) employers attitudes to the qualities of the target groups. If the new subsidies being offered are for the employer to hire additional workers and to provide them with training, this would provide the employers as a method of screening the long term unemployed at lower cost than otherwise. But if there is an excess supply of potential workers, who have not been stigmatised by long term unemployment, why should employers hire the long term unemployed? 
The Great Recession has seen a massive increase in unemployment and long term unemployment in most OECD countries. Most earlier evaluations of Active Labour Market Policy emphasise that the policies have a relatively small impact on unemployment, that it differs from country (or group of countries) to country (another group of countries), and that they are expensive to carry out. Card et al. (2010) in an interesting meta-analysis find that job search assistance programs are relatively successful, that training programs (especially onthe-job-training) are successful in the medium term, and that public sector employment programs are less effective. However, the analysis does not control for the overall level of unemployment (or long term unemployment) at the time of the evaluations.

In an important survey, Imbens and Wooldridge (2009) discuss the significant problems in evaluations. An important point made by them is that, in general, all evaluations ignore the general equilibrium aspects: “...a labor market program that affects the labor market outcomes for one individual potentially has an effect on the labor market outcomes for others. In a world with a fixed number of jobs, a training program could only redistribute jobs.” (Imbens and Wooldridge, 2009, p. 13, italics added).

Given that some countries have double digit unemployment rates (and that is not allowing for underemployment or hidden unemployment) there are only a limited number of jobs available. If we help one unemployed (or long term unemployed) person, it is likely to be at the expense of another person. Active labour market policies should have an equity goal, besides an efficiency goal. In a situation of high and increasing long term unemployment, if ALMPs can simply share the burden of unemployment between different people (groups) and do not lead to any net increase in employment (decrease in unemployment) it should be accepted as an equity success, not an efficiency failure. Even a redistribution of unemployment over different persons may have an efficiency bonus if long term unemployment leads to a person becoming disengaged permanently from the labour market.

There is some evidence to suggest that there has been a shift in Okun's Law equation and in the Beveridge Curve, see IMF (2010), OECD (2010a) perhaps due to the labour market reforms of the past two decades.

Given the serious nature of the problem of long term unemployment, we need to use macroeconomic policy instruments to stimulate aggregate demand and to introduce active 
labour market policies ${ }^{16}$. Policies to stimulate aggregate demand could be slanted towards helping the OECD economies to meet their Kyoto targets of reducing green house gas emissions. It is difficult to propose labour market policies that would suit all or most of the OECD countries since their experience had been very different. However, in some sense it would be socially valuable to concentrate on targeting active labour market policies on the young long term unemployed as they should not get disengaged from the labour force. Increasing resentment amongst the young long term unemployed is likely to store up serious social problems for the future. It would be good if OECD countries introduced a job guarantee scheme at least for the young long term unemployed. Given budget constraints it would (perhaps) be difficult to introduce a job guarantee scheme for all the long term unemployed. Ideally, we should "profile” those people who are likely to become long term unemployed (usually the disadvantaged groups in society) and target labour market policies towards them before they become long term unemployed. In these circumstances, the only policies that can be recommended are the use of increased emphasis on subsidising job search and a job guarantee scheme targeted at the long term unemployed (or preferably, those who are likely to become long term unemployed $)^{17}$.

A job guarantee scheme, as was provided in Australia in the 1990s was based on firms being subsidised to hire an additional long term unemployed person. Clearly, subsidising employers should be based on subsidies being paid only if there was an increase in the stock of employed persons in that firm, a marginal employment subsidy.

As we have seen there is a variety of experience faced by different OECD countries. Those countries that faced a financial crisis and a housing market collapse will most likely take much longer to recover from this crisis. The increased uncertainty caused by the financial crisis in some countries, notably the USA, will likely mean that unemployment and long term unemployment will remain high. In addition, the collapse of the housing market will slow down mobility from one area to another.

\footnotetext{
${ }^{16}$ Atkinson (2008) argues "Government budgets are under stress, but citizens are going to expect that, if funds can be found to rescue banks, then governments can fund unemployment benefits and employment subsidies. If governments can take on the role of lender of last resort, then we should be willing to see government as the employer of last resort."

${ }^{17}$ Some economists would argue that we should either cut the generosity of unemployment benefits or the duration over which benefits are paid. However, in a crisis situation when jobs are scarce it is unlikely to make any difference to unemployment or long term unemployment. In fact, the aggregated demand effects of cutting unemployment benefits would likely aggravate the unemployment and long term unemployment problems.
} 
Those countries that had significant falls in average hours worked are likely to have a slow recovery in terms of new jobs as workers will return to normal hours of work. Germany is an interesting case where the policy of short time working prevented a large increase in unemployment, but its recovery has been rapid due to its expansion of exports.

\section{Conclusions}

For many countries in the OECD, the Great Recession has led to a significant growth of long term unemployment. Countries that faced financial crises accompanied by a housing market collapse are likely to face continuing uncertainty that would slow down any economic recovery, hence leading to continuing problems with long term unemployment. For some OECD countries where they had a big increase in short time working (for example in Germany and Japan) economic recovery may be one of a job-less recovery as employer increase working hours for existing workers and hence delaying the fall in unemployment and long term unemployment. This paper has shown that long term unemployment is a serious problem in most OECD countries and that, in general, it follows the growth of unemployment with a lag. The experience of long term unemployment has serious social and economic consequences and policies should be introduced to help the long term unemployed. As argued earlier, we need to combine aggregate demand expansion measures along with active labour market policies.

Overall, the findings of our research are that there are many differences between the impact of the Great Recession on different countries. Countries that faced a significant financial crisis and a collapse of the housing market bubble have had large increases in unemployment and long term unemployment. There was a big fall in employment in the (especially) construction and manufacturing industries. The financial collapse led to an increase in unemployment in the financial and business sector. As a result of these twin shocks labour mobility of the unemployed is likely to be affected: with negative equity in housing, unemployed workers are unlikely to move regionally. With a loss of wealth (in housing and financial assets, including superannuation) there will be a fall in consumer spending which will slow down the recovery of economies. This means that, especially for some countries, there will be a long period of high unemployment and long term unemployment. 
There are still many uncertainties about the tentative recoveries in some countries: the UK which had a small increase in GDP in the third quarter had a fall in the fourth quarter of 2010. Countries like Portugal, Spain and Italy are still facing significant problems and it is still too early to see the end of the crisis of long term unemployment. 


\section{References}

Aaronson, D, B. Mazumder, and S. Schechter (2010) What is behind the rise in longterm unemployment”, Federal Reserve Bank of Chicago, Economic Perspectives, 2Q, 2010.

Allegretto, Sylvia and D. Lynch (2010) "The composition of the unemployed and long-term unemployed in tough labor markets”, Monthly Labor Review, October, 318.

Atkinson, A.B. (2008) Unequal Growth, Unequal Recession”, OECD Observer No. 270/271, December 2008-January 2009.

Ball, L. (2009) "Hysteresis in Unemployment: Old

and New Evidence”, NBER WP 14818.

Blanchard, O. and L. Summers (1986) "Hysteresis and the European Unemployment Problem” in S. Fischer (ed.) NBER Macroeconomics Annual 1986.

Blanchard, O. and L. Summers (1986) Hysteresis and the European Unemployment Problem, in S. Fischer (ed.) NBER Macroeconomics Annual 1986.

Blanchard, O. and P. Diamond (1989) “The Beveridge Curve”, Brookings Papers on Economic Activity, 1, 1-60.

Borland, J. and Yi-Peng Tseng (2003) “Does “Work for the Dole” work?”, Melbourne Institute of Applied Economics and Social Research, University of Melbourne, Melbourne.

Borland, J. and Yi-Peng Tseng (2007) "Does a Minimum Job Search Requirement Reduce the Time on Unemployment Payments?” Industrial and Labor Relations Review, 60 (3), 357-378.

Butterworth, P., L.S. Leach, L.Strazdins, S.C. Olesen, B. Rodgers, and D.H. Broom (2011) "The psychosocial quality of work determines whether employment has benefits for mental health: results from a longitudinal national household panel survey”, Occup. Environ. Med., 1-7.

Calmfors, L. (1994) “Active Labour Market Policy and Unemployment- A Framework for the Analysis of Crucial Design Features”, OECD Economic Studies (22), 7-47. 
Card, D., J. Kluve, and Andrea Weber (2010) “Active Labour Market Policy

Evaluations: A Meta-Analysis”, Economic Journal, 120, F452-F477.

Chapman, B.J., P.N. Junankar \& C.A. Kapuscinski (1992) "Projections of Long Term Unemployment", Australian Bulletin of Labour, Vol. 18, No. 3, September 1992, pp.195-207.

Couch, K.A. and D.W. Placzek (2010) “Earnings Losses of Displaced Workers Revisited”, American Economic Review, 100 (1), 572-589.

Dao, Mai \& Prakash Loungani (2010) “The Human Cost of Recessions: Assessing it, Reducing it”, IMF Staff Position Note, SPN/10/17, November 11, 2010.

Eichorst, W., Veronica Escudero, P. Marx, and S.Tobin (2010) The impact of the crisis on employment and the role of the labour market institutions”, ILO, Geneva.

Elsby, M.W.L., A. Hobijn, and A. Ahin (2010) “The Labor Market in the Great Recession: Comments and Discussion”, Brookings Papers on Economic Activity, Spring, 1-69.

Gamberoni, Elisa, E. Von Uexkull, and S. Weber (2010) “The Roles of Openness and Labor Market Institutions for Employment Dynamics during Economic Crises”, World Bank Economic Premise, Number 29 (forthcoming as an ILO Working Paper, 2011).

Guichard, Stephanie \& Elena Rusticelli (2010) “Assessing the Impact of the Financial Crisis on Structural Unemployment in OECD Countries”, OECD Economics Department Working Paper No. 767.

Haskel, J. and R. Jackman (1988) "Long-Term Unemployment in Britain and the Effects of the Community Programme”, Oxford Bulletin of Economics and Statistics, 50 (4), 379-408.

Heckman, J.J., R.J. Lalonde, and J.A. Smith (1999) “The Economics and Econometrics of Active Labor Market Programs”, in Handbook of Labor Economics, Volume 3A, edited by Orley Ashenfelter and David Card, Elsevier, Amsterdam. 
International Monetary Fund (2010) “Unemployment Dynamics During Recessions and Recoveries: Okun's Law and Beyond”, Chapter 3, World Economic Outlook, April, 69-107.

Imbens, G.W. and J.M. Wooldridge (2009) "Recent Developments n the Econometrics of Program Evaluation”, Journal of Economic Literature, 47 (1), 5-86.

Jackman, R. and R. Layard (1991) “Does Long-Term Unemployment Reduce a Person’s Chance of a Job: A Time-Series Test”, Economica, 58 (229), 93-106.

Jacobson, L., R. LaLonde, and D. Sullivan (1993) “Earnings Losses of Displaced Workers”, American Economic Review, 83 (4), 685-709.

Johnson, G.E. and P.R.G. Layard (1986) "The Natural Rate of Unemployment: Explanations and Policy", in Handbook of Labor Economics, eds. Orley Ashenfelter and R. Layard, Amsterdam: Elsevier Science Publishers.

Junankar, P.N. (1986 ) Costs of Unemployment: Main Report Luxembourg: Office for the Official Publications of the European Communities, 1986, (Pp. vi + 111).

Junankar, P.N. (1987) Social Costs of Unemployment: Annex to Costs of Unemployment Luxembourg: Office for the Official Publications of the European Communities, 1987, (Pp. 34).

Junankar, P.N. (1988) Very-Long-Term Unemployment (Ed.) Luxembourg: Office for the Official Publications of the European Communities, 1988, (pp. 142).

Junankar, P.N \& C.A. Kapuscinski (1991) "The Incidence of Long Term Unemployment in Australia", Australian Bulletin of Labour, Vol. 17, No. 4, pp. 325352.

Junankar, P.N. \& C.A. Kapuscinski (1992) The Costs of Unemployment in Australia, Economic Planning Advisory Council, Background Paper No. 24, Canberra, AGPS, 1993, (Pp. 63).

Junankar, P.N. (2000) Economics of Unemployment: Causes, Consequences and Policies, (Ed.), (4 volumes), International Library of Critical Writings, Edward Elgar Publishing Limited, Cheltenham). 
Junankar, P.N. and J.B. Madsen (2004) “Unemployment in the OECD: Models and Mysteries”, IZA Discussion Paper No. 1168.

Machin, S. \& A. Manning (1999) "The Causes and Consequences of Long-term Unemployment in Europe”, in Handbook of Labor Economics Vol. 3, eds. O. Ashenfelter and D. Card, Elsevier Science.

Martin, J.P. (2000) “What Works Among Active Labour Market Policies: Evidence from OECD Countries Experiences”, OECD Economic Studies, 30, 79-113.

Mortensen, D.T. and C.A. Pissarides (1999) "New Developments in Models of Search in the Labor Market”, in Handbook of Labor Economics, vol. 3, edited by O.C.

Ashenfelter and D. Card, Amsterdam: North Holland.

OECD (2002) “The ins and outs of long-term unemployment”, Chapter 4, OECD Employment Outlook 2002.

OECD (2009) “The Jobs Crisis: What are the Implications for Employment and Social Policy”, Chapter 1, OECD Employment Outlook 2009.

OECD (2010a) “Moving Beyond the Jobs Crisis”, OECD Employment Outlook 2010, 15-102.

OECD (2010b) “Labour Markets and the Crisis”, OECD Economics Department Working Paper No.756.

Saunders, P. and R. Taylor (2002) The Price of Prosperity: The Economic and Social Costs of Unemployment, UNSW Press, Sydney.

Shimer, R. (2007) “Reassessing the Ins and Outs of Unemployment”, University of Chicago, http://sites.google.com/site/robertshimer/research/workingpapers.

Stewart, M. (2007) “The Interrelated Dynamics of Unemployment and Low-Wage Employment”, Journal of Applied Econometrics, 22, 511-531.

Webster, D. (2005) “Long-term unemployment, the invention of 'hysteresis' and the misdiagnosis of structural unemployment in the UK”, Cambridge Journal of Economics, 29, 975-995. 
Woodbury, S.A. and R.G. Spiegelman (1987) "Bonuses to Workers and Employers to Reduce Unemployment: Randomised Trials in Illinois”, American Economic Review, 77 (4), 513-530. 


\section{Appendix}

Figure A1: Annual Percentage Change in Unemployment Rates, G7 (less DEU)

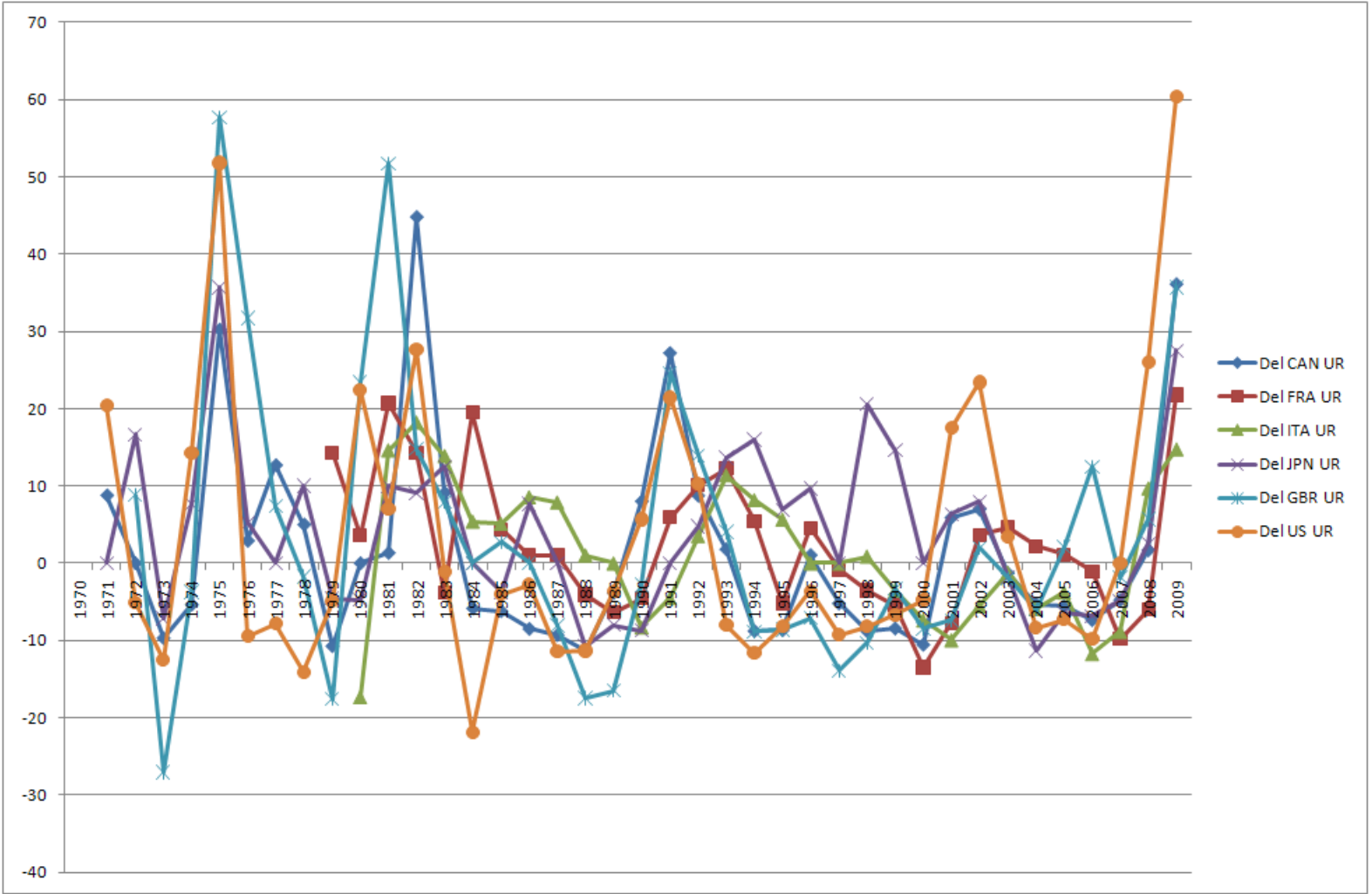

Figure A2: Percentage Change in PLTU, G7

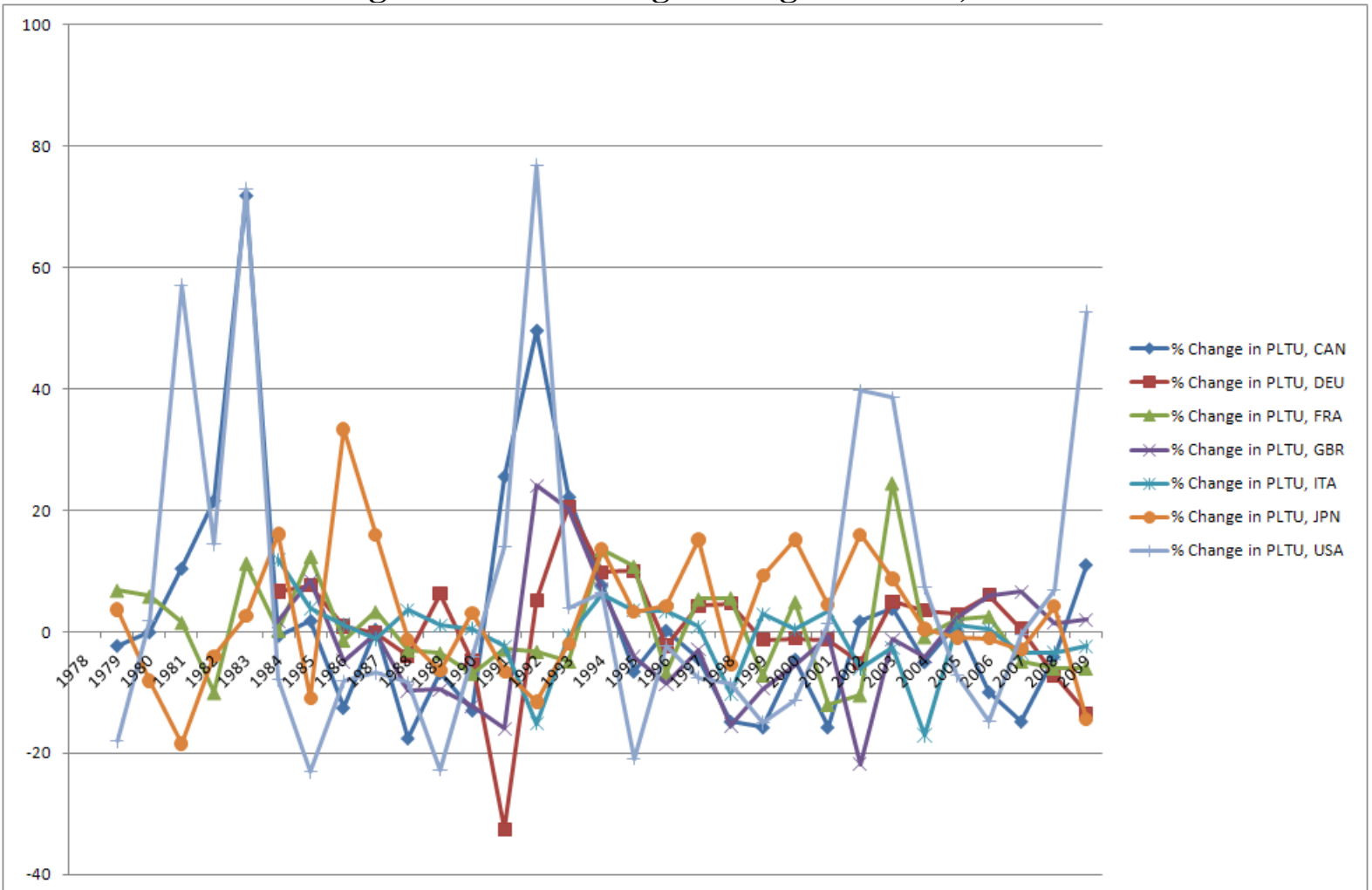

The above graphs for the annual percentage changes in unemployment rates and in PLTU for the G7. The movements in the series are remarkably similar! 
Appendix Table A1

\begin{tabular}{|l|c|c|}
\hline & $\begin{array}{l}\text { Variance } \\
\text { UR }\end{array}$ & $\begin{array}{l}\text { Variance } \\
\text { PLTU }\end{array}$ \\
\hline CAN & 3.3 & 12.4 \\
\hline FRA & 2.7 & 31.9 \\
\hline DEU & 1.2 & 9.8 \\
\hline ITA & 3.2 & 97.8 \\
\hline JPN & 1.5 & 62.6 \\
\hline GBR & 6.2 & 53.1 \\
\hline US & 2.1 & 8.4 \\
\hline
\end{tabular}


Appendix Table 11 Pooled and Fixed Effects Regressions on Quarterly Data

\begin{tabular}{|c|c|c|}
\hline & pltu ( $\left(\begin{array}{l}\text { (Pooled) } \\
\text { ) }\end{array}\right.$ & $\begin{array}{l}\text { (2) } \\
\text { pltu (FE }\end{array}$ \\
\hline l1ur & $\begin{array}{r}0.443 \\
(1.11)\end{array}$ & $\begin{array}{r}0.143 \\
(0.38)\end{array}$ \\
\hline 12ur & $\begin{array}{l}-0.151 \\
(-0.24)\end{array}$ & $\begin{array}{l}-0.372 \\
(-0.62)\end{array}$ \\
\hline 13ur & $\begin{array}{l}1.095^{*} \\
(1.71)\end{array}$ & $\begin{array}{l}1.049^{*} \\
(1.74)\end{array}$ \\
\hline luur & $\begin{array}{l}-1.285^{* * *} \\
(-3.19)\end{array}$ & $\begin{array}{r}-0.00782 \\
(-0.02)\end{array}$ \\
\hline l1pltu & $\begin{array}{l}0.691 * * * \\
(20.87)\end{array}$ & $\begin{array}{l}0.555^{* * *} \\
(17.00)\end{array}$ \\
\hline 12pltu & $\begin{array}{r}-0.00476 \\
(-0.12)\end{array}$ & $\begin{array}{l}-0.0528 \\
(-1.39)\end{array}$ \\
\hline 13pltu & $\begin{array}{c}0.181^{* * *} \\
(4.50)\end{array}$ & $\begin{array}{c}0.151^{* * *} \\
(3.97)\end{array}$ \\
\hline 14pltu & $\begin{array}{l}0.112 * * * \\
(3.43)\end{array}$ & $\begin{array}{c}0.108 * * * \\
(3.45)\end{array}$ \\
\hline q2 & $\begin{array}{l}1.473 * * * \\
(4.93)\end{array}$ & $\begin{array}{c}1.323 * * * \\
(4.71)\end{array}$ \\
\hline q3 & $\begin{array}{l}\Theta .767^{* *} \\
(2.56)\end{array}$ & $\begin{array}{l}0.712^{* *} \\
(2.53)\end{array}$ \\
\hline$q 4$ & $\begin{array}{l}1.001^{* * *} \\
(3.27)\end{array}$ & $\begin{array}{c}1.006 * * * \\
(3.50)\end{array}$ \\
\hline gfc & $\begin{array}{l}-0.893 \\
(-1.33)\end{array}$ & $\begin{array}{c}-1.884 * * * \\
(-2.83)\end{array}$ \\
\hline gfcl1ur & $\begin{array}{l}-2.073^{* * *} \\
(-3.39)\end{array}$ & $\begin{array}{l}-1.730^{* * *} \\
(-2.98)\end{array}$ \\
\hline gfcl2ur & $\begin{array}{l}2.855^{* * *} \\
(2.77)\end{array}$ & $\begin{array}{c}2.538^{* * *} \\
(2.62)\end{array}$ \\
\hline gfcl3ur & $\begin{array}{r}0.491 \\
(0.45)\end{array}$ & $\begin{array}{l}-0.203 \\
(-0.20)\end{array}$ \\
\hline gfcl4ur & $\begin{array}{l}-0.996 \\
(-1.45)\end{array}$ & $\begin{array}{l}-0.101 \\
(-0.16)\end{array}$ \\
\hline gfclipltu & $\begin{array}{l}0.0361 \\
(0.61)\end{array}$ & $\begin{array}{r}-0.00946 \\
(-0.17)\end{array}$ \\
\hline gfcl2pltu & $\begin{array}{l}0.198 * * * \\
(2.76)\end{array}$ & $\begin{array}{c}0.179 * * * \\
(2.64)\end{array}$ \\
\hline gfcl3pltu & $\begin{array}{l}-0.235^{* * *} \\
(-3.35)\end{array}$ & $\begin{array}{c}-0.222^{* * *} \\
(-3.37)\end{array}$ \\
\hline gfcl4pltu & $\begin{array}{l}-0.0371 \\
(-0.65)\end{array}$ & $\begin{array}{r}-\odot .0 \odot \odot 262 \\
(-\odot .0 \odot)\end{array}$ \\
\hline _cons & $\begin{array}{l}-0.824^{* *} \\
(-2.27) \\
1342\end{array}$ & $\begin{array}{r}0.728 \\
(1.15) \\
1342\end{array}$ \\
\hline
\end{tabular}


Equation 1 (Pooled)

R-squared $=0.9496$

Adj R-squared $=0.9488$

Tests for Structural Break:

$F(9,1321)=6.81$

Prob $>F=0.0000$

Equation 2 (Fixed Effects)

R-sq: within $=0.7565$

between $=0.9632$

overall $=0.9245$

Tests for Structural Break:

$F(9,1292)=7.29$

Prob $>F=0.0000$ 


\section{Appendix: Estimates of Outflow Rates}

A further analysis we carried out was to calculate outflow rates from data on unemployment stocks as follows:

$$
\begin{gathered}
\mathrm{U}_{\mathrm{t}}=\mathrm{U}_{\mathrm{t}-1}+\mathrm{I}_{\mathrm{t}}-\mathrm{X}_{\mathrm{t}} \\
\text { or } \\
\mathrm{X}_{\mathrm{t}}=\mathrm{U}_{\mathrm{t}-1}-\mathrm{U}_{\mathrm{t}}+\mathrm{I}_{\mathrm{t}}
\end{gathered}
$$

Where exits, $X_{t}$ are derived by using the identity that the stock of unemployment at time $t$, equals the stock at time (t-1), plus the inflows into the unemployment stock minus the outflows (exits) from the unemployment stock. Unfortunately, we do not have data on inflows so we use an approximation. We assume that all those in the unemployment duration of one month (or less) are the inflows into the unemployment stock. However, this is an approximation, since many of the inflows into the unemployment stock outflow very rapidly and hence this is likely to be an underestimate of the true inflows. However, it provides us with a simple series on the outflows. The outflow rate is then calculated as the outflows (exits) divided by the unemployment stock. This calculated outflow rate series is a fairly noisy series and confusing if different country series were presented on one graph. As such the series are presented below for some of the OECD countries. 
Figure 18 a: USA Outflow Rate

USA Outflow Rate

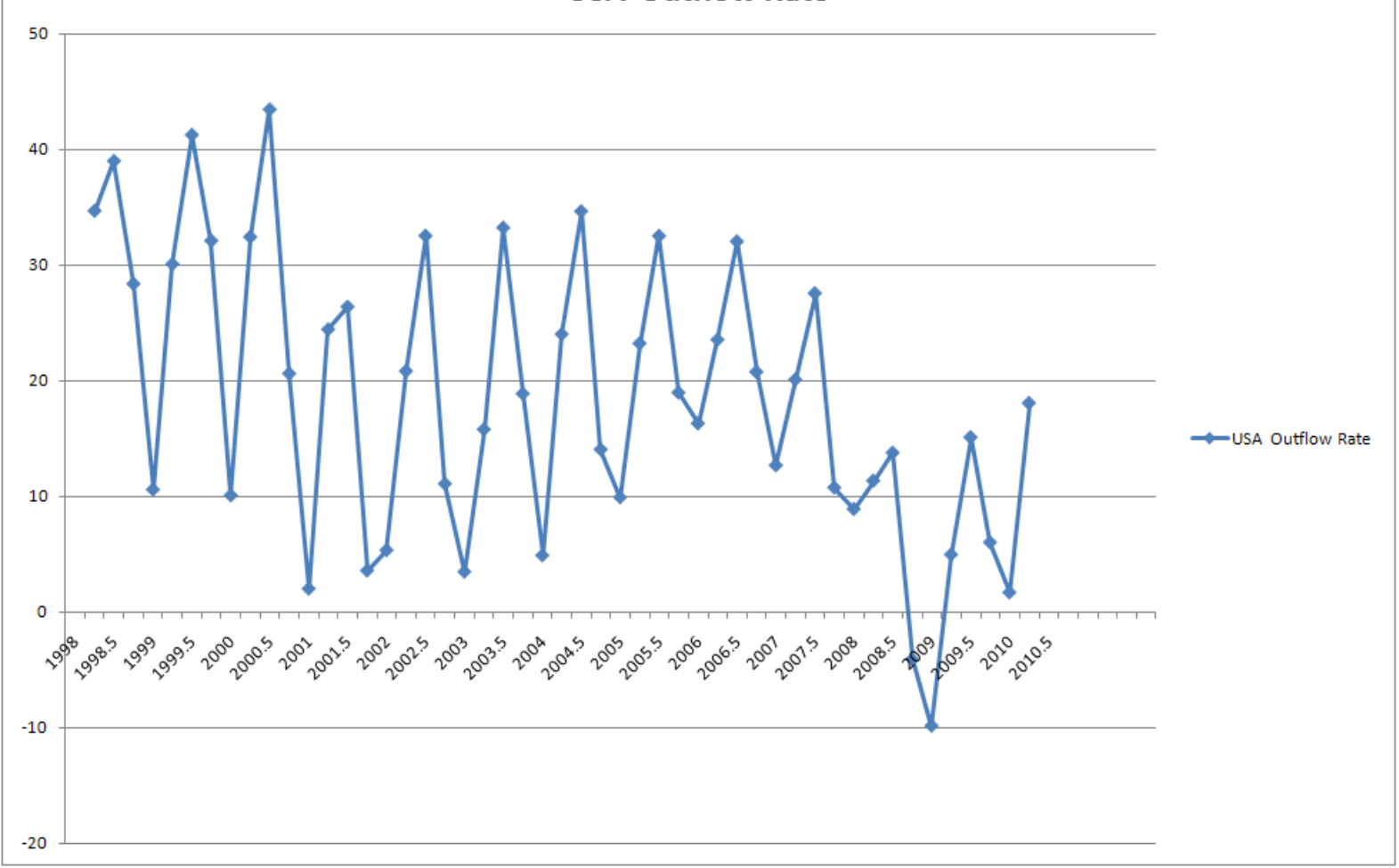

Source: U Flows, derived from OECD duration by age and gender.

Figure 18 b: UK Outflow Rate

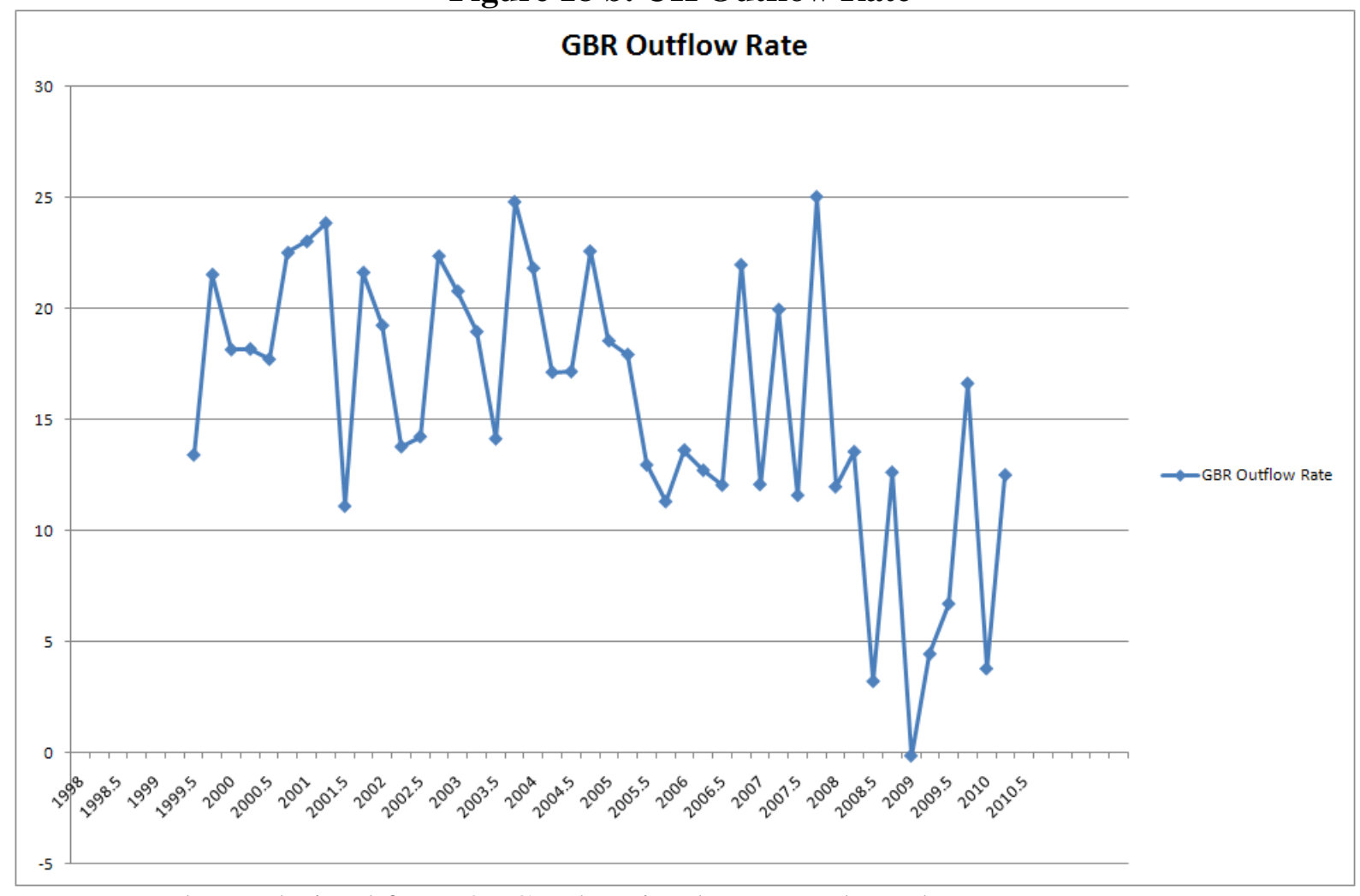

Source: U Flows, derived from OECD duration by age and gender.

84 
Figure 18 c: Spain Outflow Rate

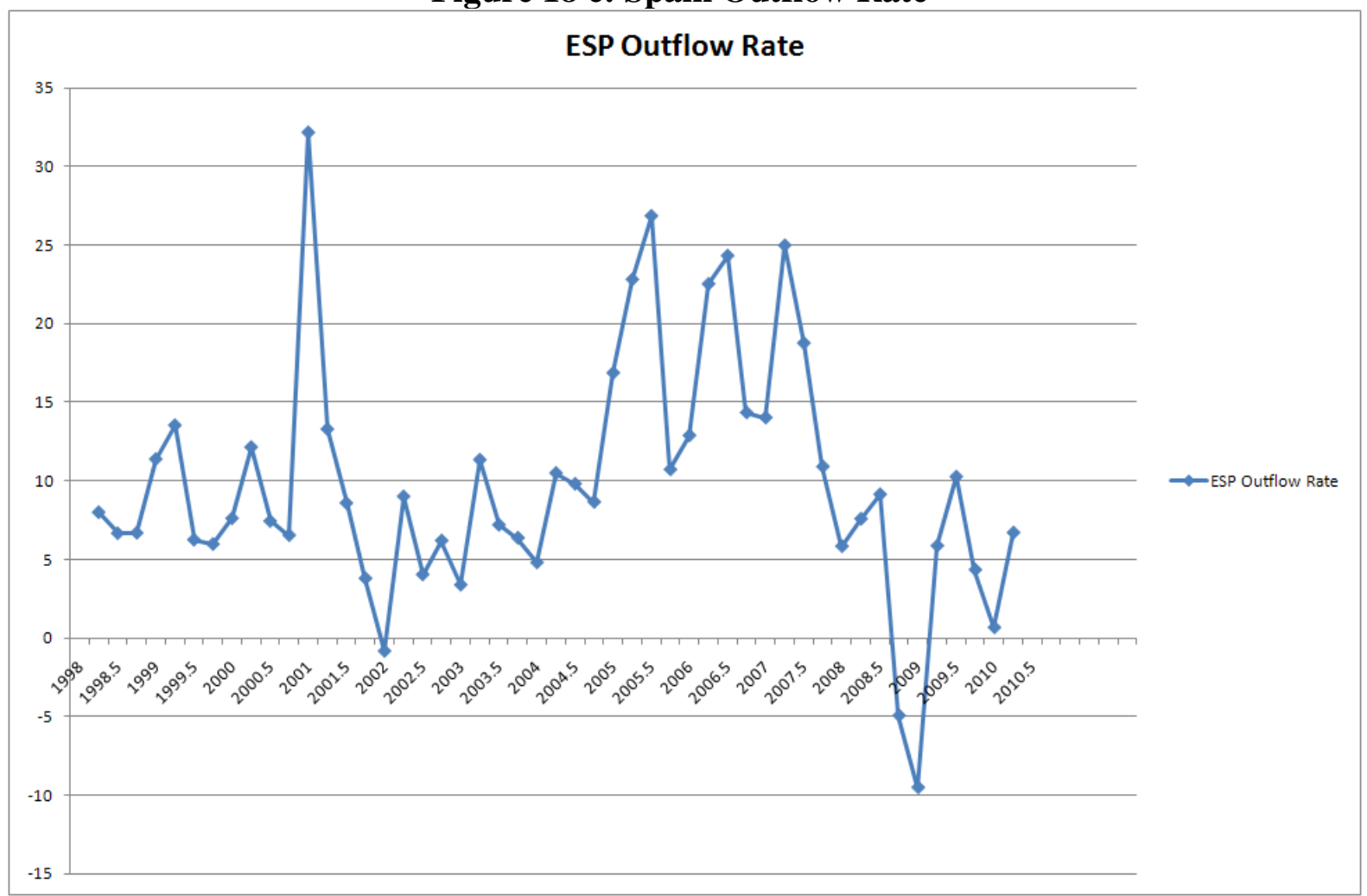

Source: U Flows, derived from OECD duration by age and gender.

The calculated series for the outflow rates show clearly that the outflow rates fall suddenly in recessions, especially in the Great Recession. However, the estimated or calculated series are very crude and clearly have some problems as these series become negative (which is clearly infeasible!). Shimer (2007) has argued that the increase in US unemployment is primarily due to a fall in outflows from unemployment. OECD (2009, p. 52) also argue that the outflow rates are primarily responsible in explaining fluctuations in unemployment. Elsby, Hobijn, and Ahin (2010) find that in the Great Recession the increases in unemployment and long term unemployment were initially caused by an increase of inflows into unemployment (job loss), but there was a large decrease in the outflow rate causing the huge increases in long term unemployment. They also argue that an improvement in the unemployment rate would require an increase in the exit probabilities (outflow rate).

Over the past decade many countries increased labour market flexibility with an increasing number of workers on temporary contracts and flexibility to alter working hours, see IMF (2010). Those on temporary contracts or casual workers would be the first to lose their jobs and hence increase the responsiveness of unemployment to output changes. On the other hand, flexibility of working hours may lead firms to cut working hours rather than laying off 
workers. Countries that had regulations about severance pay may have had a lower rate of retrenchment, and led firms to use short time working, see Gamberoni, Uexkull, and Weber (2011). As a result when the economy recovers, it may lead to a "jobless recovery' for some time. 